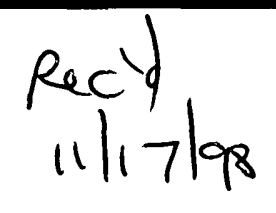

\title{
Application of Nonlinear-Regression Methods to a Ground-Water Flow Model of the Albuquerque Basin, New Mexico
}

Water-Resources Investigations Report 98-4172

Prepared in cooperation with the

CITY OF ALBUQUERQUE PUBLIC WORKS DEPARTMENT and the

NEW MEXICO OFFICE OF THE STATE ENGINEER

U.S. DEPARTMENT OF THE INTERIOR

U.S. GEOLOGICAL SURVEY 


\section{Application of Nonlinear-Regression Methods to a Ground-Water Flow Model of the Albuquerque Basin, New Mexico}

By Claire R. Tiedeman, John Michael Kernodle, and Douglas P. McAda

U.S. GEOLOGICAL SURVEY

Water-Resources Investigations Report 98-4172

Prepared in cooperation with the

CITY OF ALBUQUERQUE PUBLIC WORKS DEPARTMENT and the

NEW MEXICO OFFICE OF THE STATE ENGINEER 


\title{
U.S. DEPARTMENT OF THE INTERIOR \\ BRUCE BABBITT, Secretary
}

\author{
U.S. GEOLOGICAL SURVEY
}

Thomas J. Casadevall, Acting Director

The use of firm, trade, and brand names in this report is for identification purposes only and does not constitute endorsement by the U.S. Geological Survey.

For additional information write to:

District Chief

U.S. Geological Survey Water Resources Division 4501 Indian School Road NE, Suite 200

Albuquerque, NM 87110-3929
Copies of this report can be purchased from:

U.S. Geological Survey

Branch of Information Services

Box 25286

Denver, CO 80225-0286 


\section{CONTENTS}

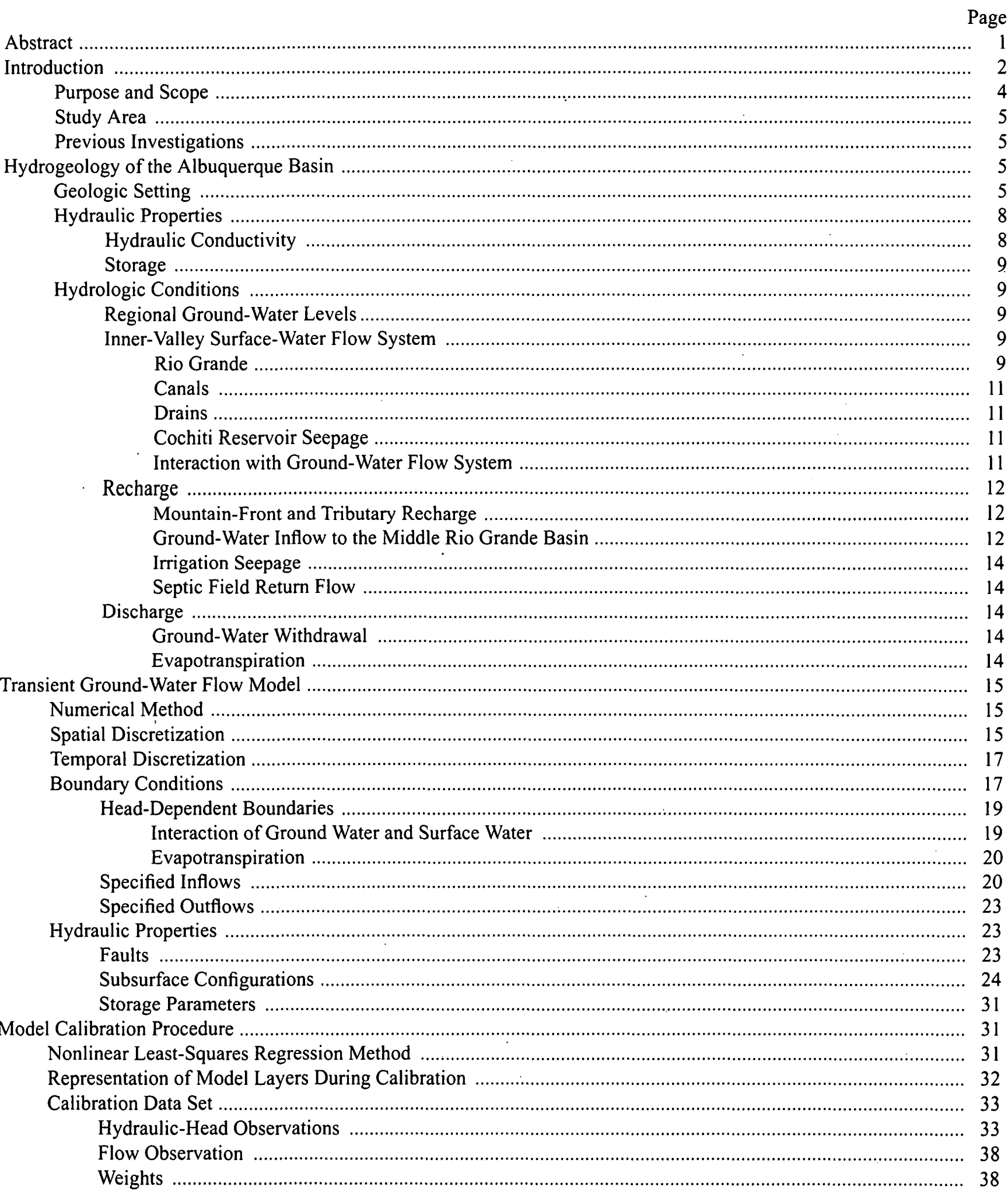


Sensitivities

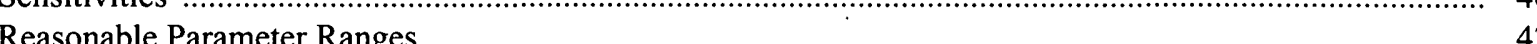

Model Evaluation

Model Linearity and Normality of Weighted Residuals

Optimal Parameter Estimates

Model Fit and Model Error

Standard Error of Regression

Weighted Hydraulic-Head Residuals

Simulated and Observed Hydraulic Heads

Weighted Flow Residual and Simulated Flow

Basinwide Simulated Conditions

Hydraulic Heads

Ground-Water Budget

Summary and Conclusions

References Cited

Appendix: Modifications to MODFLOWP

Subroutine FLW1RP

Subroutine SSEN1D

Subroutine SSEN1K

Subroutine SSEN1V

\section{FIGURES}

1-12. Maps showing:

1. Location of the Albuquerque Bașin in central New Mexico.....

2. Physiographic features in the vicinity of the Albuquerque Basin

3. Major geologic and tectonic features in the vicinity of the Albuquerque Basin.........................................

4. Contours of ground-water levels that represent winter 1994-95 conditions in the Santa Fe Group aquifer system in the Albuquerque Basin and locations of wells used to construct contours

5. Mountain-front and tributary recharge and underflow, in acre-feet per year, estimated by water-budget methods or inferred from numerical simulations of ground-water flow in adjacent basins

6. Plan view of finite-difference grid

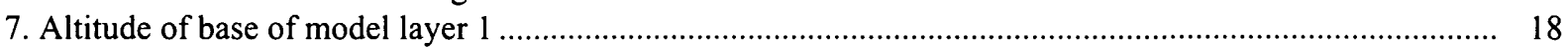

8. Locations of recharge zones in the ground-water flow model ............................................................... 21

9. Hydraulic-conductivity zones in the ground-water flow model ....................................................... 25

10. Locations of wells for which hydraulic-head measurements for (A) the 1950's, (B) 1992, and (C) 1994 are included in the calibration data set.....

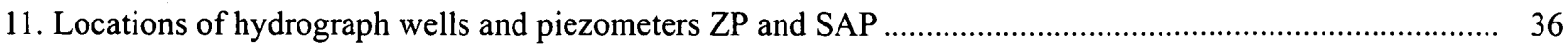

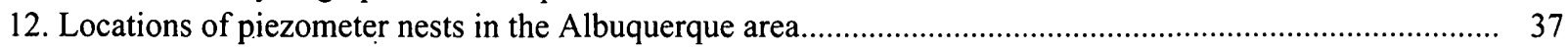

13-17. Graphs showing:

13. Composite scaled sensitivities calculated using the initial parameter values for the model with subsurface configuration 1 .

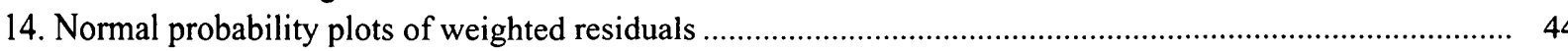

15. Optimal parameter estimates and approximate, linear 95 -percent confidence intervals ............................. 46

16. Composite scaled sensitivities calculated using the optimal parameter estimates in calibrations 2,4 , and 6

17. Weighted residuals against weighted simulated values.

18. Maps showing spatial distribution of weighted hydraulic-head residuals during the 1950's for (A) calibration 4 and (B) calibration 6, during 1992 for (C) calibration 4 and (D) calibration 6, and during 1994 for (E) calibration 4 and $(\mathrm{F})$ calibration 6 .

19. Graphs showing temporal distribution of weighted hydraulic-head residuals

20. Maps showing spatial distribution of differences between simulated and observed hydraulic heads during the 1950's for (A) simulation 4 and (B) simulation 6, during 1992 for (C) simulation 4 and (D) simulation 6, and during 1994 for $(\mathrm{E})$ simulation 4 and $(\mathrm{F})$ simulation 6. 
21. Maps showing spatial distribution of differences between simulated and observed hydraulic heads in the

Albuquerque area during 1992 for (A) simulation 4 and (B) simulation 6, and during 1994 for

(C) simulation 4 and (D) simulation 6

22-23. Graphs showing:

22. Observed and simulated hydraulic heads at hydrograph wells

23. Observed and simulated hydraulic heads at piezometer nests

24-27. Maps showing:

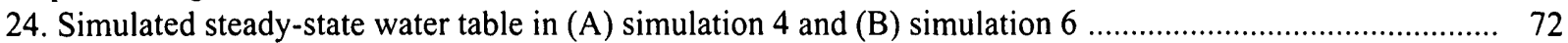

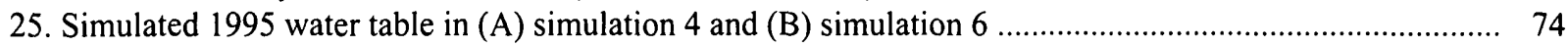

26. Simulated 1995 hydraulic heads in model layer 5 in (A) simulation 4 and (B) simulation 6 .....................75

27. Simulated 1995 hydraulic heads in model layer 7 in (A) simulation 4 and (B) simulation 6 .................. 76

28-30. Graphs showing:

28. Simulated flow between inner-valley surface-water bodies and the ground-water system......................... 77

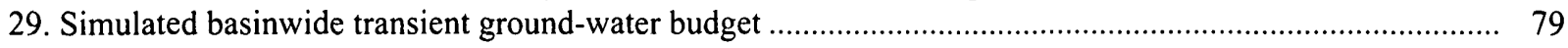

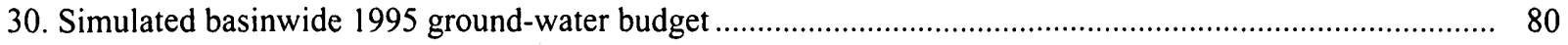

\section{TABLES}

1. Model input values for head-dependent boundaries simulated with the river package of MODFLOW

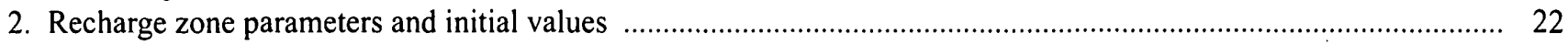

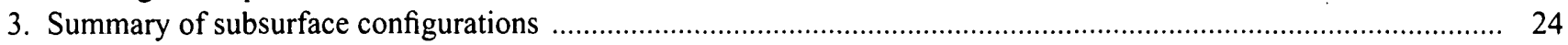

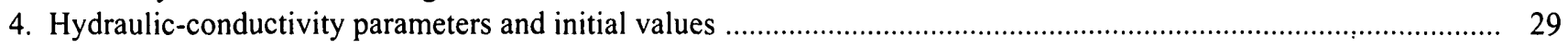

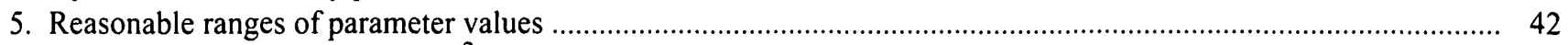

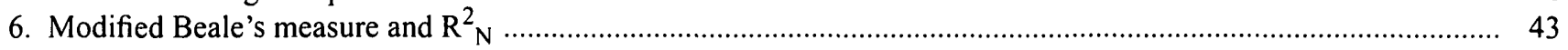

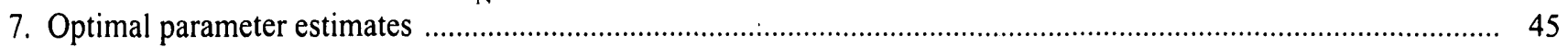

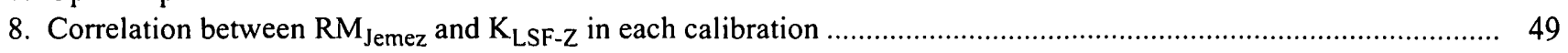

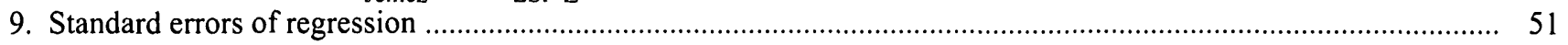

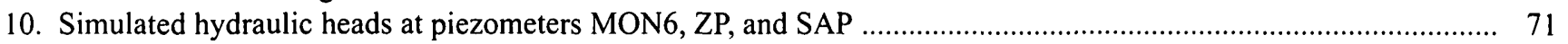

\section{CONVERSION FACTORS AND VERTICAL DATUM}

\begin{tabular}{rll}
\hline Multiply & \multicolumn{1}{c}{ By } & To obtain \\
\hline inch & 2.54 & centimeter \\
foot & 0.3048 & meter \\
mile & 1.609 & kilometer \\
square mile & 2.59 & square kilometer \\
acre-foot per acre & 0.3048 & cubic meter per square meter \\
acre-foot per year & 3.379 & cubic meter per day \\
foot per day & 0.3048 & meter per day \\
foot per year & 0.3048 & meter per year \\
cubic foot per second & 0.02832 & cubic meter per second \\
gallon & 3.785 & liter \\
\hline
\end{tabular}

Temperature in degrees Fahrenheit $\left({ }^{\circ} \mathrm{F}\right)$ may be converted to degrees Celsius $\left({ }^{\circ} \mathrm{C}\right)$ as follows:

$$
{ }^{\circ} \mathrm{C}=\left({ }^{\circ} \mathrm{F}-32\right) / 1.8
$$

Sea level: In this report, "sea level" refers to the National Geodetic Vertical Datum of 1929-a geodetic datum derived from a general adjustment of the first-order level nets of the United States and Canada, formerly called Sea Level Datum of 1929. 


\title{
Application of Nonlinear-Regression Methods to a Ground- Water Flow Model of the Albuquerque Basin, New Mexico
}

\author{
By Claire R. Tiedeman, John Michael Kernodle, and Douglas P. McAda
}

\section{Abstract}

This report documents the application of nonlinear-regression methods to a numerical model of ground-water flow in the Albuquerque Basin, New Mexico. In the Albuquerque Basin, ground water is the primary source for most water uses. Ground-water withdrawal has steadily increased since the 1940's, resulting in large declines in water levels in the Albuquerque area. A ground-water flow model was developed in 1994 and revised and updated in 1995 for the purpose of managing basin ground-water resources. In the work presented here, nonlinear-regression methods were applied to a modified version of the previous flow model. Goals of this work were to use regression methods to calibrate the model with each of six different configurations of the basin subsurface and to assess and compare optimal parameter estimates, model fit, and model error among the resulting calibrations.

The Albuquerque Basin is one in a series of north trending structural basins within the Rio Grande Rift, a region of Cenozoic crustal extension. Mountains, uplifts, and fault zones bound the basin, and rock units within the basin include pre-Santa Fe Group deposits, Tertiary Santa Fe Group basin fill, and post-Santa Fe Group volcanics and sediments. The Santa Fe Group is greater than 14,000 feet $(\mathrm{ft})$ thick in the central part of the basin. During deposition of the Santa Fe Group, crustal extension resulted in development of north trending normal faults with vertical displacements of as much as $30,000 \mathrm{ft}$.

Ground-water flow in the Albuquerque Basin occurs primarily in the Santa Fe Group and
post-Santa Fe Group deposits. Water flows between the ground-water system and surfacewater bodies in the inner valley of the basin, where the Rio Grande, a network of interconnected canals and drains, and Cochiti Reservoir are located. Recharge to the ground-water flow system occurs as infiltration of precipitation along mountain fronts and infiltration of stream water along tributaries to the Rio Grande; subsurface flow from adjacent regions; irrigation and septic field seepage; and leakage through the Rio Grande, canal, and Cochiti Reservoir beds. Ground water is discharged from the basin by withdrawal; evapotranspiration; subsurface flow; and flow to the Rio Grande, canals, and drains.

The transient, three-dimensional numerical model of ground-water flow to which nonlinearregression methods were applied simulates flow in the Albuquerque Basin from 1900 to March 1995. Six different basin subsurface configurations are considered in the model. These configurations are designed to test the effects of (1) varying the simulated basin thickness, (2) including a hypothesized hydrogeologic unit with large hydraulic conductivity in the western part of the basin (the west basin high-K zone), and (3) substantially lowering the simulated hydraulic conductivity of a fault in the western part of the basin (the low-K fault zone). The model with each of the subsurface configurations was calibrated using a nonlinear least-squares regression technique. The calibration data set includes 802 hydraulic-head measurements that provide broad spatial and temporal coverage of basin conditions, and one measurement of net flow from the Rio Grande and drains to the ground-water system in 
the Albuquerque area. Data are weighted on the basis of estimates of the standard deviations of measurement errors. The 10 to 12 parameters to which the calibration data as a whole are generally most sensitive were estimated by nonlinear regression, whereas the remaining model parameter values were specified.

Results of model calibration indicate that the optimal parameter estimates as a whole are most reasonable in calibrations of the model with subsurface configurations 3 (which contains 1,600-ft-thick basin deposits and the west basin high-K zone), 4 (which contains 5,000-ft-thick basin deposits and the west basin high-K zone), and 6 (which contains 5,000-ft-thick basin deposits and the low-K fault zone). The presence in the model of either the west basin high-K zone or the low-K fault zone results in lower simulated hydraulic heads in the western part of the basin, which improves the model fit at some headobservation locations. Without either of these features in the model, the regression tended to lower heads in the western part of the basin by increasing the estimates of some hydraulicconductivity parameters such that they are outside the ranges of values expected on the basis of prior information. In calibrations 3,4 , and 6 , the estimate of the hydraulic conductivity of the undivided upper part of the Santa Fe Group remains outside the expected range of values, although the estimate is much closer to this range than in the other calibrations. This result indicates that the model is not yet completely satisfactory and strongly suggests that further modifications need to be made to the conceptual model of the basin hydrology and geology that is implemented in the numerical flow model.

Although the model is not yet completely satisfactory, evaluation of weighted residuals and of simulated hydraulic heads and ground-water budgets for calibrations with the most reasonable parameter estimates is useful for identifying model error and for assessing the differences between the calibrations. Evaluation of calibrations 4 and 6 shows that the spatial distribution and magnitudes of the weighted hydraulic-head residuals do not differ significantly between these two calibrations. Detailed analyses of the weighted residuals indicate that model fit is generally good at shallow wells in the central and southern parts of the basin but is fair to poor at basin margins and in the north. At deep wells in the Albuquerque area, model fit is generally good for simulations of conditions during the 1950's but worsens for conditions in the 1990's, suggesting that model error related to the representation of pumpage could increase with simulation time. Evaluation of patterns in the spatial distribution of weighted residuals indicates likely error in the representation of hydrogeologic units in the southern and northern parts of the basin.

Assessment of model fit to observed vertical hydraulic gradients at piezometer nests suggests that vertical anisotropy is not uniform throughout the basin and that underflow at depth may be a larger source of inflow to the northwestern part of the basin than is simulated in the model.

In some parts of the basin, there are major differences between simulations 4 and 6 . West of the low-K fault zone in subsurface configuration 6 , hydraulic heads in simulation 6 are as much as 160 $\mathrm{ft}$ higher than those in simulation 4 . Net recharge from precipitation and stream water is about 12,000 acre- $\mathrm{ft} / \mathrm{yr}$ larger in simulation 4 than in simulation 6 , mostly because of a larger optimal estimate of recharge along the Jemez River in calibration 4. This difference results in greater discharge from the ground-water system to the inner-valley surface-water bodies in the southern part of the basin.

\section{INTRODUCTION}

In the Albuquerque Basin, central New Mexico (fig. 1), ground water is the primary water source for all municipal, industrial, and domestic uses except agricultural irrigation. Ground-water withdrawals in the Albuquerque area steadily increased from the 1940 's to the mid-1990's, resulting in large declines in water levels. Since the early 1900 's, regulatory, scientific, and academic entities have studied the hydrogeology of the basin. Beginning in the 1980's, numerical models of ground-water flow within the basin have been constructed. The goals of these 


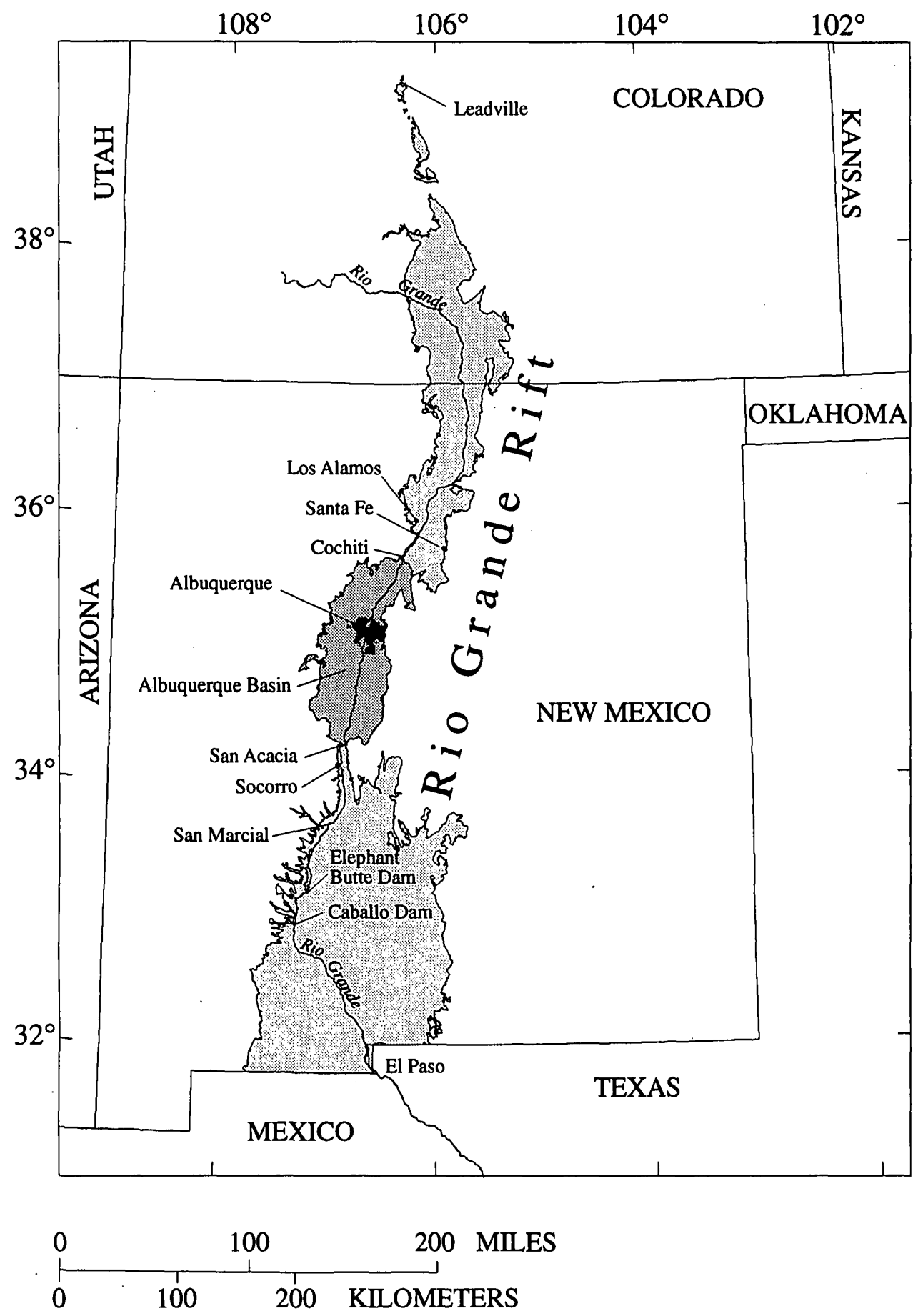

Figure 1. Location of the Albuquerque Basin in central New Mexico (modified from Thorn and others, 1993, fig. 1). 
hydrogeologic and modeling studies are to characterize the basin geology and the ground-water and surfacewater flow systems and to use this knowledge to help manage the water resources of the basin.

In the early 1990's, the New Mexico Bureau of Mines and Mineral Resources, in cooperation with the City of Albuquerque, synthesized the hydrogeologic framework of the Albuquerque Basin (Hawley and Haase, 1992) and the U.S. Geological Survey, in cooperation with the City of Albuquerque, synthesized knowledge of the basin geohydrology (Thorn and others, 1993). In 1994 and 1995, the U.S. Geological Survey developed numerical ground-water flow models of the basin on the basis of this geologic and hydrologic understanding (Kernodle and others, 1995; Kernodle, 1998). To realistically represent basin features, the spatial and temporal discretization used in these flow models was very fine. Consequently, obtaining the model solution, which is the spatial and temporal distribution of hydraulic heads and flows within the basin, was computationally intensive and required several hours using available computers. Because of the large computational time required, these models were not rigorously calibrated. Instead, reasonable values of model parameters were assumed, using field estimates as well as knowledge of and inferences about hydrologic and geologic conditions in the basin.

In 1995, the U.S. Geological Survey and other agencies began the 5-year Middle Rio Grande Basin study to improve the understanding of water resources in and around the Albuquerque Basin (Bartolino, 1997; Slate, 1998). For the purposes of the 5-year study, the Middle Rio Grande Basin is loosely defined as the area in the vicinity of the Rio Grande Rift between Santa Fe and Los Alamos to the north and Socorro to the south (fig. 1). As so defined, the Middle Rio Grande Basin includes the Albuquerque Basin, defined in this report as the area of Cenozoic deposits within the Rio Grande Rift between Cochiti and San Acacia (fig. 1). This definition of the Albuquerque Basin is consistent with that in Thorn and others (1993), Kernodle and others (1995), and Kernodle (1998).

The 5-year Middle Rio Grande Basin study includes geologic and fault mapping, geophysical investigations of the subsurface, and generation of high-resolution cartographic data to aid geologic mapping and land surface analysis within the basin. Hydrologic aspects of the 5-year study include several investigations of recharge along mountain fronts and tributaries to the Rio Grande, collection and interpretation of ground-water age data, and field studies of the interaction of ground water and surface water in the basin. The work described in this report, which involves application of nonlinear regression to a ground-water flow model of the Albuquerque Basin, is also part of the 5-year Middle Rio Grande Basin study.

\section{Purpose and Scope}

The purpose of this report is to document the application of nonlinear-regression methods to a numerical model of ground-water flow in the Albuquerque Basin. The primary goals of this work were to use regression methods to (1) calibrate the model with six different configurations of the basin subsurface, and (2) assess and compare the optimal parameter estimates, model fit, and model error among the resulting calibrations. Several steps were involved in accomplishing these goals. The spatial and temporal discretization in the models of Kernodle and others (1995) and Kernodle (1998) was coarsened, so that solving for hydraulic heads and flows is less computationally intensive than in the previous models. Alternative configurations of the subsurface were developed, which differ in (1) their simulated thickness of basin deposits, (2) whether or not a highly permeable hydrogeologic unit in the western part of the basin is included in the model, and (3) whether or not the simulated hydraulic conductivity of a fault zone in the western part of the basin is substantially lowered. Hydraulic-head and flow data in the basin were chosen for inclusion in the calibration data set and assigned appropriate weights. The sensitivities of these data to the flow-model parameters were assessed and used to determine which of the model parameters to estimate. A nonlinear-regression technique was applied to the model with each of the subsurface configurations to estimate the optimal parameter values for each, and the reasonableness of the optimal estimates was assessed. Diagnostic procedures associated with the use of regression methods were used to evaluate model fit and model error for the subset of calibrations with the most reasonable parameter estimates. Simulated basinwide hydraulic heads and ground-water budgets were also compared for these calibrations. 


\section{Study Area}

The Albuquerque Basin occupies an area of about 3,060 square miles in central New Mexico (fig. 1). The basin is one in a series of north trending structural basins within the Rio Grande Rift, a region of Cenozoic crustal extension extending from central Colorado into northern Mexico. The Rio Grande enters the basin from the northeast near Cochiti Pueblo, and flows out of the basin through a basin-fill constriction near San Acacia in the south (fig. 2). Major tributaries to the Rio Grande include the Jemez River and Rio Puerco. Land-surface altitudes of the basin-fill deposits range from about 4,800 feet (ft) above sea level at the southern edge of the basin to about $6,000 \mathrm{ft}$ above sea level in the north.

The climate is semiarid, and long-term average precipitation ranges from about 8 inches near the Rio Grande to about 23 inches at the crest of the Sandia Mountains (Thorn and others, 1993, table 1), which form part of the eastern basin boundary. Mean annual temperatures range from about $56^{\circ} \mathrm{F}$ near the Rio Grande to $38^{\circ} \mathrm{F}$ at the crest of the Sandia Mountains.

\section{Previous Investigations}

Investigations of geologic and hydrologic conditions in the Albuquerque Basin began in the early 1900 's. The frequency of these studies began to increase in the 1960's. Thorn and others (1993) and McAda (1996) provided comprehensive summaries of these investigations. The geology and hydrology of the basin were recently described by Hawley and Haase (1992), Thorn and others (1993), and Hawley and others (1995). Additional investigations are currently being conducted. Studies being carried out by the U.S. Geological Survey to refine the understanding of the basin hydrogeology are described in workshop proceedings edited by Bartolino (1997) and by Slate (1998).

Several three-dimensional numerical models of ground-water flow in the basin have been constructed. Kernodle and Scott (1986) developed a model of steady-state ground-water flow, and Kernodle and others (1987) expanded this model to simulate transient conditions. Later, Kernodle and others (1995) developed a new transient model of ground-water flow in the basin. Compared with the earlier flow models, this model more realistically represented the interaction of the ground-water and surface-water flow systems in the inner valley and incorporated recent geologic interpretations of the subsurface. Kernodle (1998) presented a revised version of the model of Kernodle and others (1995), in which representation of some hydrogeologic conditions was updated.

\section{HYDROGEOLOGY OF THE ALBUQUERQUE BASIN}

\section{Geologic Setting}

The Albuquerque Basin is one of several structural basins that are part of the Rio Grande Rift, a region formed by Cenozoic extension that stretches from Colorado through the length of central New Mexico into northern Mexico (fig. 1). The primary period of extension occurred from about 30 million years ago (Ma) to about $5 \mathrm{Ma}$, with tectonism most active from about $15 \mathrm{Ma}$ to $5 \mathrm{Ma}$ (Thorn and others, 1993). Structural boundaries of the basin are the Nacimiento Uplift and Jemez Mountains to the north; the La Bajada Escarpment to the northeast; the Sandia, Manzano, and Los Pinos Uplifts to the east; the Joyita and Socorro Uplifts to the south; the Ladron Uplift to the southwest; and the Lucero Uplift and the Rio Puerco Fault Zone to the west (fig. 3). The Albuquerque Basin is defined as the extent of Cenozoic deposits within these structural boundaries. The Rio Grande flows through constrictions in the northeastern and southern boundaries of the basin, where the eastern. and western structural features converge. Basin fill is continuous across these boundaries (Hawley and Haase, 1992, p. II-4).

Rock units in the Albuquerque Basin include pre-Santa Fe deposits, Tertiary Santa Fe Group basin fill, post-Santa Fe Pleistocene volcanic rock, and postSanta Fe Quaternary sediments. The ensuing discussion of the depositional history, lithology, and thicknesses of the Santa Fe and post-Santa Fe deposits is condensed from Hawley and Haase (1992), Thorn and others (1993), and Hawley and others (1995); these works describe the understanding of the geologic history and depositional structure of the basin as of the early to mid-1990's. Geologic and geophysical studies are currently being conducted to further characterize the location, extent, and properties of the depositional units in the basin (Bartolino, 1997; Slate, 1998).

The predominant basin deposit is the Santa Fe Group, the thickness of which ranges from about 3,000 


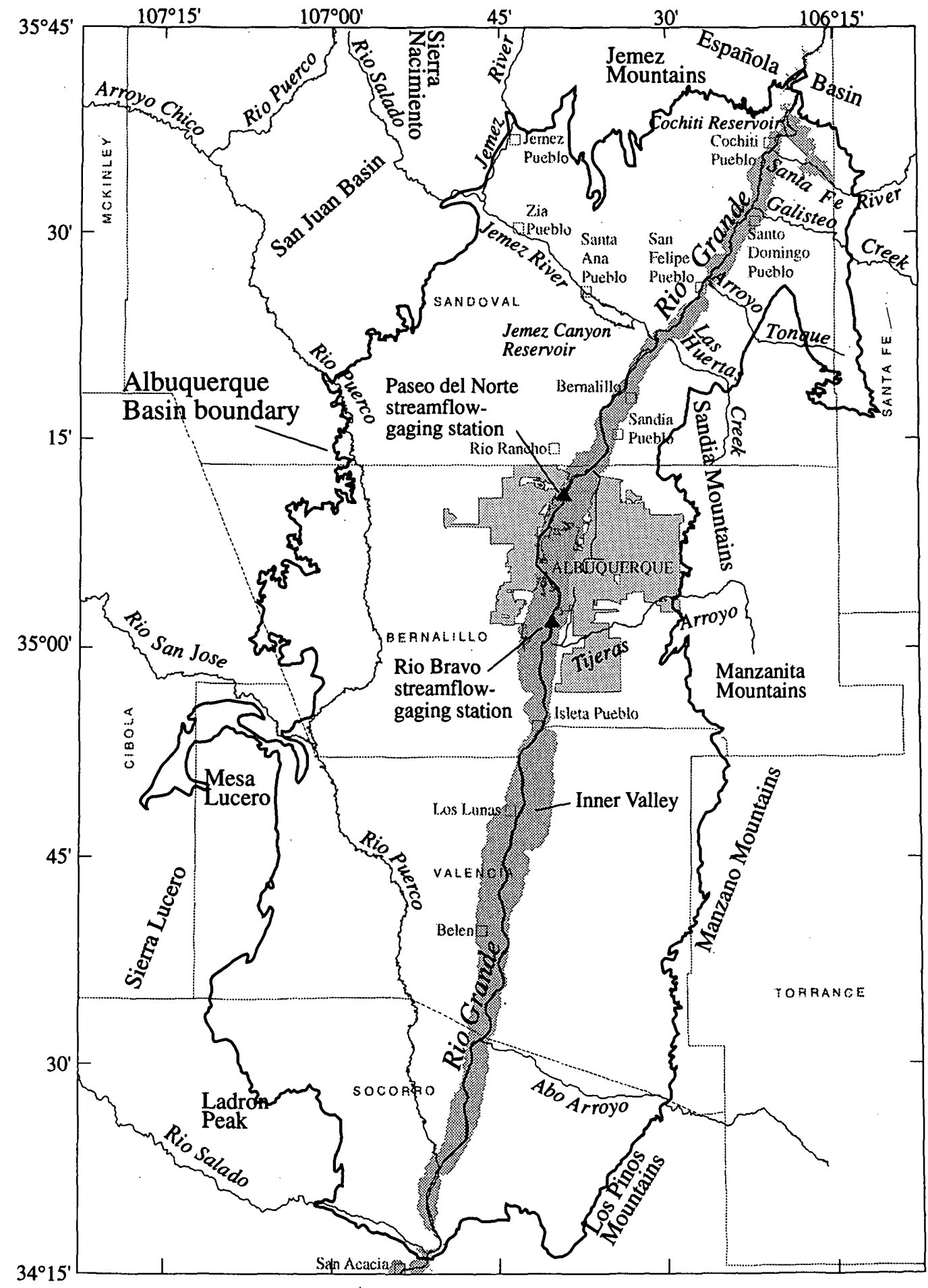

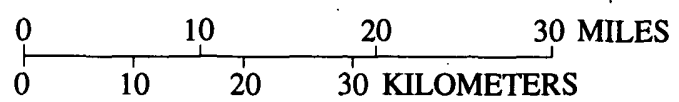

Figure 2. Physiographic features in the vicinity of the Albuquerque Basin. 


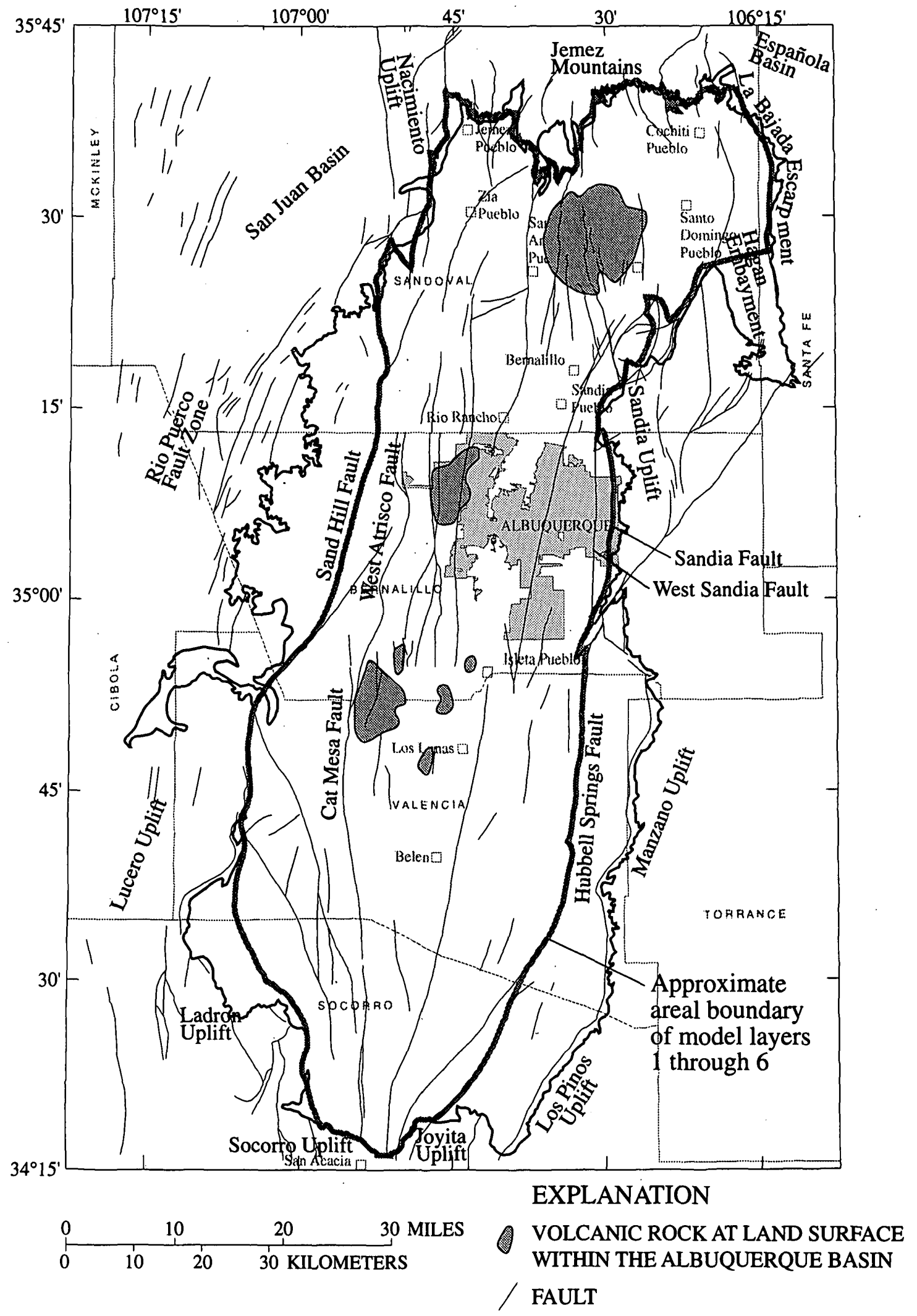

Figure 3. Major geologic and tectonic features in the vicinity of the Albuquerque Basin (modified from Kelley, 1977; Thorn and others, 1993, fig. 4; Kernodle, 1998, fig. 14). 
to $4,000 \mathrm{ft}$ along basin margins to greater than 14,000 $\mathrm{ft}$ in the center of the basin. The Santa Fe Group has been divided into lower, middle, and upper parts, on the basis of depositional environment and age. The lower part of the Santa Fe Group was deposited during the Oligocene and Miocene from about $30 \mathrm{Ma}$ to $15 \mathrm{Ma}$, when the basin was internally drained, and contains piedmont-slope, eolian, and basin-floor playa deposits. The thickness of the lower part of the Santa Fe Group ranges from less than $1,000 \mathrm{ft}$ along basin margins to about 3,500 $\mathrm{ft}$ in the basin center. The middle part of the Santa Fe Group was deposited during the Miocene and early Pliocene from about $15 \mathrm{Ma}$ to $5 \mathrm{Ma}$, during the time of greatest accumulation of sediments in the basin. During this time, piedmont-slope deposition continued and fluvial systems developed, transporting sediments into the basin and most likely terminating in playa lakes within the basin. The thickness of the middle part of the Santa Fe Group ranges from about 250 to $9,000 \mathrm{ft}$. The upper part of the Santa Fe Group was deposited during the Pliocene and early

Pleistocene from about $5 \mathrm{Ma}$ to $1 \mathrm{Ma}$. During this time, the ancestral Rio Grande developed, entering the basin from the north and flowing out to the south. The upper part of the Santa Fe Group contains piedmont-slope and fluvial sediments, and is as much as $1,500 \mathrm{ft}$ thick. The axial-channel sands and gravels of the upper part of the Santa Fe Group, deposited by the ancestral Rio Grande, are especially coarse and well sorted.

The crustal extension that formed the Rio Grande Rift caused normal faults to develop throughout the Albuquerque Basin during deposition of the Santa Fe Group. These faults have a predominantly north-south orientation (fig. 3). At the basin margins and at depth in the central parts of the basin, the normal faults placed older, less permeable rock adjacent to parts of the Santa Fe Group. Vertical displacements are as much as 30,000 ft (Hawley and others, 1995, p. 45). Normal faulting also occurred within the Santa Fe Group deposits. Presently, many of these faults are thought to be cemented and therefore may act as partial barriers to horizontal ground-water movement.

Deposition of post-Santa Fe Group sediments has occurred from $1 \mathrm{Ma}$ to the present. In the early part of this period, the Rio Puerco and Rio Grande deposited channel and flood-plain material during river incision and backfilling episodes. In the last 10,000 to 15,000 years, these rivers have been aggrading. The recent post-Santa Fe Group alluvial deposits are on average about $80 \mathrm{ft}$ thick. Volcanic rock was emplaced in the central part of the Albuquerque Basin west of the Rio Grande from about 0.2 to $0.1 \mathrm{Ma}$. Basalt flowed to land surface along presumed fault zones. The exposed part of this rock occupies a small percentage of the basin surface area (fig. 3 ).

\section{Hydraulic Properties}

\section{Hydraulic Conductivity}

Many aquifer tests have been performed and analyzed to estimate the transmissivity of hydrogeologic units in the Santa Fe Group. Most tests were conducted in wells with screens that are a few hundred feet long. Thorn and others (1993, table 2) summarized the results of several of these aquifer tests and reported the hydraulic-conductivity estimate from each well as the transmissivity divided by the screen length of the well. Hydraulic-conductivity estimates for 22 wells with screens that penetrate only the upper part of the Santa Fe Group range from 4 to $130 \mathrm{ft} /$ day. Axial-channel deposits of the upper part of the Santa Fe Group that are beneath the City of Albuquerque generally have the largest hydraulic conductivities. Hydraulic-conductivity estimates for nine wells with screens that penetrate the upper and middle parts of the Santa Fe Group range from 7 to $71 \mathrm{ft} /$ day, the estimate for one well that penetrates the middle and lower parts of the Santa Fe Group is $0.03 \mathrm{ft} / \mathrm{day}$, and the estimate for one well that penetrates only the lower part of the Santa Fe Group is $12 \mathrm{ft} /$ day. Additional tests were performed in several wells for which the lithology is unknown.

Using an auger-hole method, Cummins (1997b) estimated the hydraulic conductivity of coarse-grained deposits in the Rio Grande alluvium to be about 90 to $350 \mathrm{ft} /$ day. Willis (1993) estimated hydraulic conductivities of 0.2 and $65 \mathrm{ft} / \mathrm{day}$, respectively, for silty clay and gravelly coarse sand within the river alluvium.

In their models of ground-water flow within the basin, Kernodle and others (1995) and Kernodle (1998) estimated horizontal hydraulic conductivities of the hydrogeologic units on the basis of aquifer tests and other field methods as well as on the basis of properties of the units described by Hawley and Haase (1992, table VI-1). These hydraulic-conductivity estimates are 0.5 to $40 \mathrm{ft} /$ day for alluvial units, 10 to $70 \mathrm{ft} /$ day for the upper part of the Santa Fe Group, $4 \mathrm{ft} /$ day for the 
middle part of the Santa Fe Group, and 2 to $10 \mathrm{ft} /$ day for the lower part of the Santa Fe Group.

Presently, there are no field-based estimates of the anisotropy ratio (defined here as the ratio of horizontal to vertical hydraulic conductivity) of deposits in the Albuquerque Basin. In 1995, a largescale aquifer test was conducted at the City of Albuquerque Griegos 1 production well located in the inner valley. Analysis of this test may yield an estimate of the anisotropy ratio of the upper part of the Santa Fe Group. The depositional setting of Santa Fe Group deposits suggests that horizontal hydraulic conductivity is likely to be greater than vertical hydraulic conductivity. The anisotropy ratio used in other three-dimensional ground-water flow models of alluvial basins in the Southwest ranges from 20 to 67,000 (Kernodle, 1992), although the ratio for most of the models falls in the narrower range of 200 to 1,000 .

\section{Storage}

There are no estimates from aquifer tests of the specific yield of aquifer materials in the Albuquerque Basin. The specific yield of the type of deposits composing the Santa Fe Group generally ranges from about 0.10 to 0.25 (Johnson, 1967). Heywood (1995) used data collected during an aquifer test in the Albuquerque area to calculate the elastic specific storage of the Santa Fe Group. Using measurements of the change in (1) aquifer thickness in an extensometer and (2) hydraulic head in piezometers, he computed an elastic specific storage of $2 \times 10^{-6}$ per foot.

\section{Hydrologic Conditions}

The following discussion of the hydrologic conditions of the Albuquerque Basin is condensed from the more detailed descriptions given by Thorn and others (1993), Kernodle and others (1995), and McAda (1996).

\section{Regional Ground-Water Levels}

Regional ground-water levels that represent conditions during winter 1994-95 are shown in figure 4 . The ground-water levels used to construct this figure were obtained from wells that penetrate different depths and have different screened interval lengths; thus, the water-level contours depict large-scale horizontal ground-water movement through the basin, but do not accurately represent smaller scale groundwater flow conditions. In addition, uniformly spaced contours are shown in some areas of sparse data, whereas the horizontal hydraulic gradient may be more variable in the true flow system. Ground water generally flows from the flanks of the basin toward the Rio Grande, and through the basin from north to south (fig. 4). In the central part of the basin, ground water flows from the Rio Grande into the aquifer, partly because of the influence of ground-water withdrawals. In the Albuquerque area east of the Rio Grande, ground-water withdrawals have significantly lowered water levels. Total pumpage from wells west of the Rio Grande is substantially less than that from wells east of the river, and thus the effect of ground-water withdrawal on ground-water levels west of the river is less pronounced than to the east.

\section{Inner-Valley Surface-Water Flow System}

The surface-water flow system in the inner valley (fig. 2) of the Albuquerque Basin includes the Rio Grande, Cochiti Reservoir, and an extensive, interconnected network of canals and drains. In some areas of the inner valley, the Rio Grande, canals, and drains recharge the ground-water flow system, whereas in other areas, ground water discharges to these surface-water bodies. Cochiti Reservoir recharges the ground-water system.

\section{Rio Grande}

The position and geometry of the Rio Grande channel have changed over time because of natural and anthropogenic activities. Locations of the river channel in 1935 and 1989 are stored in Geographic Information System (GIS) data bases of the U.S. Geological Survey (formerly data bases of the National Biological Survey), and locations in 1955, 1975, and 1992 are stored in GIS data bases of the Bureau of Reclamation (McAda, 1996). The river channel is incised into the inner valley of the basin, and the Rio Grande water level generally is within a few feet of land surface. Land-surface altitude is available from U.S. Geological Survey 1:24,000-scale topographic maps and varies at the river channel from about $5,240 \mathrm{ft}$ above sea level at the northern edge of the basin to about $4,690 \mathrm{ft}$ above sea level at the southern edge of the basin. The river bottom consists of coarse sand that is about $3 \mathrm{ft}$ thick (Gould, 1997) and underlain by finer grained deposits. The river is on average about 1 foot deep, but vortex motion of the surface water increases the river depth near its banks. Reliáble field estimates of the riverbed vertical hydraulic conductivity have not been made. 


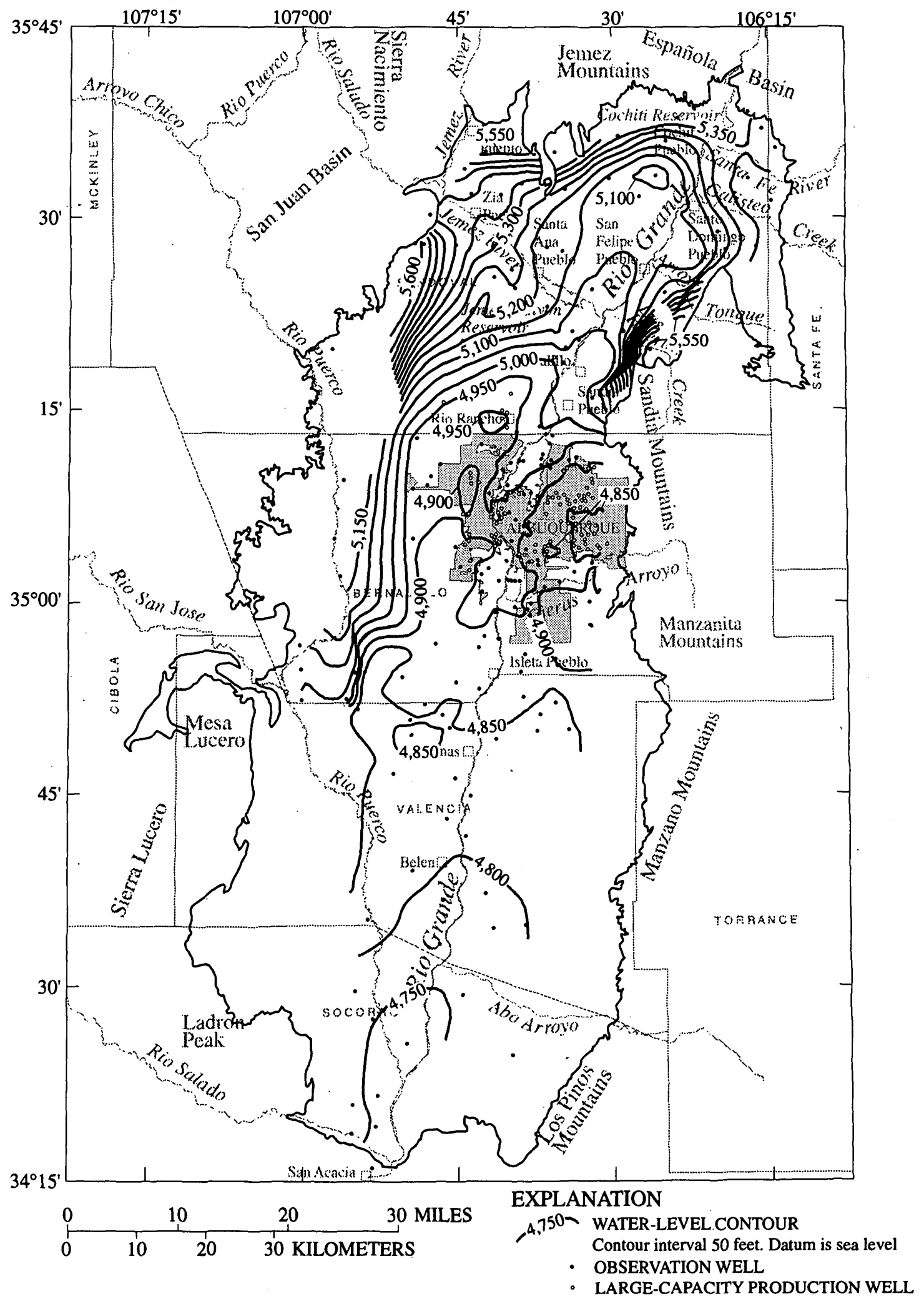

Figure 4. Contours of ground-water levels that represent winter 1994-95 conditions in the Santa Fe Group aquifer system in the Albuquerque Basin and locations of wells used to construct contours (modified from Kernodle, 1998). Observation wells are defined here as wells that are not used for large-capacity production; most have shorter screened intervals and are completed to shallower depths than are the large-capacity production wells. 


\section{Canals}

The primary function of canals is to distribute river water to irrigated areas during the irrigation season, generally from March to October. A network of canals has existed in the inner valley of the basin since at least the 1600's (Thorn and others, 1993). The distribution and positions of the canals have changed with time according to irrigation requirements and technological advances. Locations of the canals in 1955, 1975, and 1992 are stored in GIS data bases of the Bureau of Reclamation (McAda, 1996). The canal banks are generally raised above land surface, and the canal beds are approximately at land surface. Stage measurements suggest that water in canals is on average about $3 \mathrm{ft}$ deep, but that its depth can vary considerably. The canal beds generally contain silt deposited from the diverted Rio Grande water. McAda (1996) estimated the vertical hydraulic conductivity of the canal beds to be $0.14 \mathrm{ft} /$ day using canal seepage rates measured by Gould and Hansen (1997).

\section{Drains}

Interior and riverside drains were constructed in the inner valley of the Albuquerque Basin beginning in the late 1920's (Thorn and others, 1993). Interior drains lower the water table in areas where the water table is elevated because of irrigation seepage and canal leakage, discharge to ground water in areas where the hydraulic gradient is favorable, and discharge excess surface water to riverside drains. Riverside drains adjacent to the Rio Grande intercept shallow river leakage, convey this water downstream, and discharge it to the Rio Grande. Presently, the water table in the Albuquerque area is below the bottom of most interior drains because of ground-water withdrawals; therefore, these drains do not receive ground-water discharge. However, some drains convey storm runoff and excess irrigation water back to the river, and some drains supplement the canal network by conveying water to irrigated areas.

The distribution of the drain network has changed with time. Locations of the drains in 1955, 1975, and 1992 are stored in GIS data bases of the Bureau of Reclamation (McAda, 1996). The drains are incised into the inner valley and the altitude of the drain beds varies considerably, but is typically a few feet below land surface. Field estimates of drain-bed hydraulic conductivity have not been made. Because the drains mostly receive ground-water discharge, silt generally does not accumulate on the drain beds.

\section{Cochiti Reservoir Seepage}

Cochiti Reservoir is located at the northern boundary of the Albuquerque Basin (fig. 2). Impoundment of water in Cochiti Reservoir began in 1973, and mean annual water levels in the reservoir from 1974 through 1995 ranged from 5,260 to $5,390 \mathrm{ft}$ above sea level. Seepage from the reservoir to the ground-water flow system was estimated to be 84,000 acre-ft/yr in 1978 and 1979 and 21,000 acre-ft/yr in 1980 and 1981 (Blanchard, 1993). The altitude of the reservoir bed is available from 1:250,000-scale Digital Elevation Models (DEMs). Tests have not been conducted to estimate the hydraulic conductivity of the reservoir bottom sediments.

\section{Interaction with Ground-Water Flow System}

Flow of water between the surface-water system in the inner valley and the ground-water flow system varies spatially. In parts of the inner valley where the hydraulic head beneath the river, canals, or drains is lower than the stage of the surface-water body, surface water recharges the ground-water flow system. This occurs in the Albuquerque area, where water levels have declined because of ground-water withdrawals. In parts of the inner valley where the hydraulic head beneath the river, canals, or drains is greater than the stage, ground water discharges to the surface-water body.

Net flow between the ground-water and surfacewater flow systems has been estimated using measurements at streamflow-gaging stations on the Rio Grande and adjacent canals and drains at the Paseo del Norte Bridge (U.S. Geological Survey gaging station Rio Grande near Alameda) and at the Rio Bravo Bridge (U.S. Geological Survey gaging station Rio Grande at Rio Bravo Bridge near Albuquerque) (Thorn, 1995) (fig. 2). These measurements have been made on a monthly basis for several years. During the winter months of November, December, January, and February, minimal evaporation occurs, and the canals generally are not active because there are no diversions of river water for irrigation. The riverside drains capture most of the river water that is recharging the shallow ground-water flow system and convey it back to the river. Therefore, the difference in surface-water flow along the reach between the Paseo del Norte and Rio Bravo streamflow-gaging stations is an estimate of the net flow between the Rio Grande and riverside drains and the ground-water system. Most calculated differences in surface-water flow between the two 
gaging stations show a loss of water to the groundwater system. The most reliable measurements of the difference in surface-water flow over the reach are those made during times when total river discharge at a single streamflow-gaging station does not vary substantially from one day to the next. During the winters of 1989 through 1995, 15 surface-water flow measurements were made at each of the Paseo del Norte and Rio Bravo streamflow-gaging stations on days when total river discharge varied by less than about 5 percent from the day before to the day of the flow measurement. For this set of measurements, the difference in surface-water flow between the two gaging stations ranged from about 40,000-acre-feet per year (acre-ft/yr) gain in surface-water flow to about 134,000 -acre-ft/yr loss in surface-water flow, and had a median of about 29,000 -acre-ft/yr loss in surface-water flow (Thorn, 1995; J. Veenhuis, Hydrologist, U.S. Geological Survey, oral and written commun., 1998). Ten of the 15 differences are in the range of about 14,500 - to 79,600 - acre- $\mathrm{ft} / \mathrm{yr}$ loss in surface-water flow.

\section{Recharge}

The ground-water flow system of the Albuquerque Basin has several sources of recharge. Precipitation infiltrates along mountain fronts bordering the basin and surface water infiltrates along streams and arroyos that are tributary to the Rio Grande. Ground-water inflow from adjacent basins and mountains recharges the northern and southwestern parts of the Albuquerque Basin. Recharge occurs in some parts of the inner valley from surface-water bodies (discussed above) and as seepage of excess irrigation water applied to crops. Seepage from septic fields recharges the flow system in the inner valley and on the flanks of the basin.

\section{Mountain-Front and Tributary Recharge}

Recharge along most mountain fronts and major tributaries to the Rio Grande has been estimated by water-budget methods (fig. 5). These methods generally use long-term average annual precipitation; thus, temporal variation in recharge is not estimated. Kernodle and Scott (1986) used the water-budget method described by Hearne and Dewey (1988) to estimate average annual infiltration from precipitation along the slopes of the Sandia, Manzano, and Los Pinos Mountains and along Tijeras and Abo Arroyos. The total recharge rate along these mountain fronts and arroyos on the eastern side of the Albuquerque Basin was estimated to be approximately $71,700 \mathrm{acre}-\mathrm{ft} / \mathrm{yr}$. Average annual infiltration of stream water along the Jemez River, Rio Puerco, and Rio Salado was estimated by a water-budget method (J.D. Dewey, Hydrologist, U.S. Geological Survey, written commun., 1982), and reported by Kernodle and Scott (1986). Dewey also estimated that 5,200 acre-ft/yr recharges the ground-water flow system where the Rio San Jose enters the Albuquerque Basin. Kernodle and others (1995) used evapotranspiration-adjusted streamflow data to estimate infiltration along the Santa Fe River and Galisteo Creek. Jemez Canyon Reservoir, located on the Jemez River (fig. 2), was designed for 1day detention of flows greater than 30 cubic feet per second. Prior to 1979, water was not stored in the reservoir for long time periods, but since 1979 , some water has been continuously stored. Thus, Jemez Canyon Reservoir likely recharges the ground-water flow system, but this recharge has not been estimated.

Thomas (1995) estimated infiltration rates through the bed of the upper part of Tijeras Arroyo (fig. 2) near the eastern Albuquerque Basin boundary. She used streamflow loss measurements over reaches ranging in length from about 200 to $2,000 \mathrm{ft}$ and adjusted these measurements for evaporative loss from surface water. During October 1989 through May 1992, infiltration rates ranged from 2.3 to $30 \mathrm{ft} /$ day and had a median of $5.9 \mathrm{ft} /$ day. By assuming an average wetted-channel width of $4 \mathrm{ft}$ (C.L. Thomas, Hydrologist, U.S. Geological Survey, oral commun., 1998), the median infiltration rate amounts to about 400 acre-ft/yr over a 2,000-ft reach of the arroyo.

\section{Ground-Water Inflow to the Middle Rio Grande Basin}

Numerical modeling of ground-water flow in regions adjacent to the Albuquerque Basin suggests that there is ground-water inflow to the northern part of the basin (fig. 5). Using a model of ground-water flow in the Española Basin, McAda and Wasiolek (1988) estimated ground-water flow from the Española Basin to the Albuquerque Basin to be $12,600 \mathrm{acre}-\mathrm{ft} / \mathrm{yr}$. Frenzel (1995) modified the model of McAda and Wasiolek on the basis of new hydrogeologic interpretations of a part of the Española Basin and estimated ground-water inflow to the Albuquerque Basin to be 8,800 acre-ft/yr. Kernodle and others (1995) estimated ground-water inflow from the Jemez Mountains by assuming that the ground-water inflow per unit length along the boundary between the 


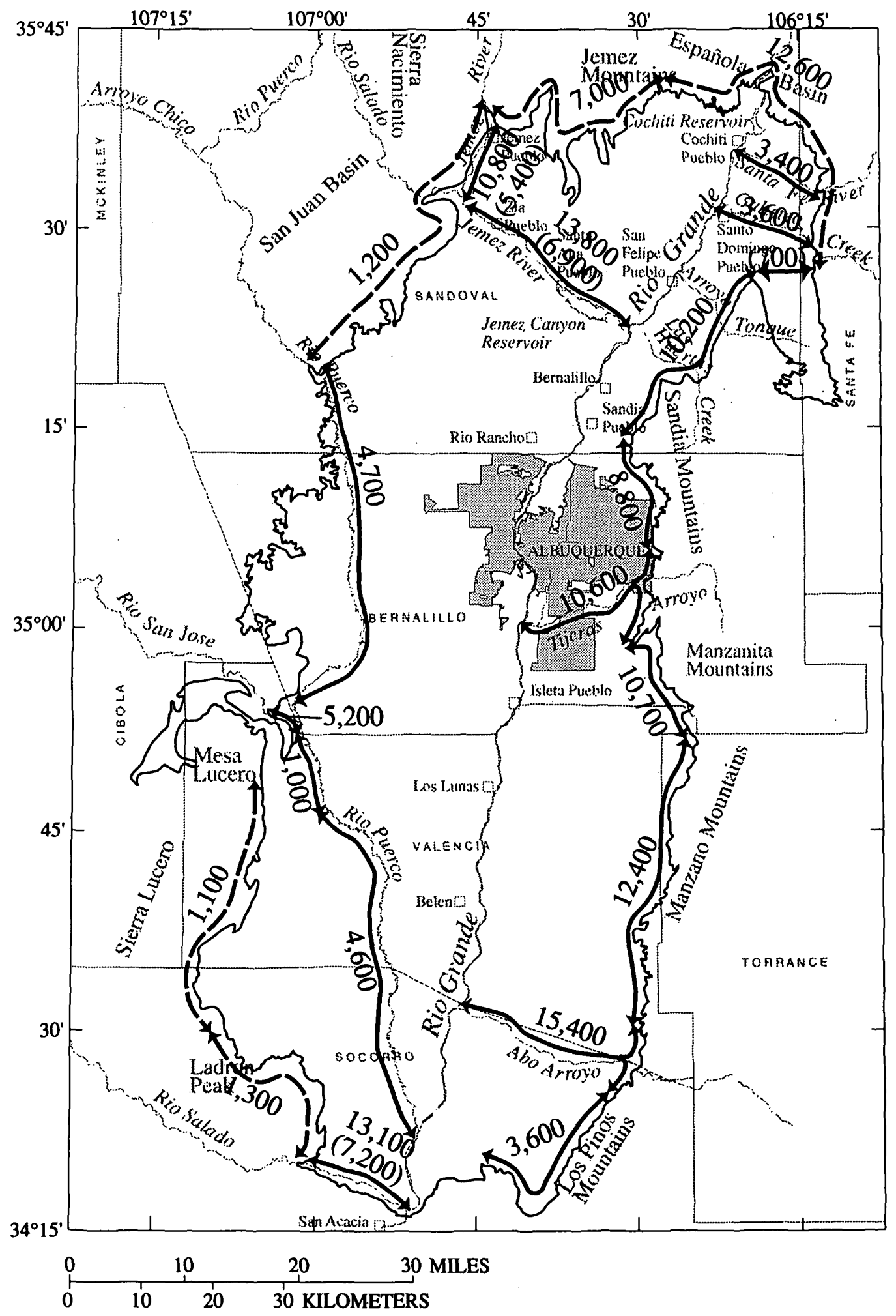

Figure 5. Mountain-front and tributary recharge (solid curves) and underflow (dashed curves), in acre-feet per year, estimated by water-budget methods or inferred from numerical simulations of ground-water flow in adjacent basins. Initial rates in the ground-water flow model are given in parentheses if different from rates estimated by the water-budget method. 
Albuquerque Basin and the Jemez Mountains is the same as the ground-water inflow per unit length along the boundary between the Albuquerque Basin and the Española Basin calculated by McAda and Wasiolek (1988). In their model of ground-water flow in the San Juan Basin, Frenzel and Lyford (1982) estimated ground-water discharge to the Albuquerque Basin to be $1,200 \mathrm{acre}-\mathrm{ft} / \mathrm{yr}$.

Underflow to the Albuquerque Basin is also thought to occur along the southwest margin of the basin (fig. 5). Using a water-budget method, J.D. Dewey (Hydrologist, U.S. Geological Survey, written commun., 1982) estimated total underflow from the Sierra Lucero and Ladron Peak region into the basin to be about 2,400 acre-ft/yr.

\section{Irrigation Seepage}

Irrigation water conveyed by the network of canals supports agriculture in the inner valley of the Albuquerque Basin. Bjorklund and Maxwell (1961, p. 53) estimated that 3 acre-ft per acre per year is typically applied to crops in the inner valley and that about onethird of this water recharges the water table. Cummins (1997a) estimated that the amount of irrigation water applied ranges from 1.1 to 4.2 acre-ft per acre per year and on average is 2.5 acre-ft per acre per year. He estimated that seepage to the water table from applied water ranges from 0.10 to 1.22 acre-ft per acre per year. The distribution of irrigated areas in the inner valley in 1935, 1955, 1975, and 1992 is available in GIS data bases (McAda, 1996).

\section{Septic Field Return Flow}

Kernodle and others (1995) used City of Albuquerque, Bernalillo County, and U.S. Bureau of Census data together with the assumption that per capita septic discharge is 75 gallons per day to estimate the location and quantity of septic field return flow within the Albuquerque Basin. They estimated that total septic field return flow in 1970, 1980, and 1990 was approximately $8,700,9,400$, and 9,900 acre-ft/yr, respectively.

\section{Discharge}

Ground water is discharged from the Albuquerque Basin primarily as withdrawal by pumped wells, evapotranspiration, and flow to surfacewater conveyances in parts of the inner valley (discussed above). Ground water also flows to the
Socorro Basin across the southern Albuquerque Basin boundary (Kernodle and Scott, 1986). This underflow is believed to be small compared with other basinboundary flows.

\section{Ground-Water Withdrawal}

Ground water is the primary water source in the Albuquerque Basin for all uses except agricultural irrigation. The City of Albuquerque is the largest consumer of ground water in the basin. Ground-water withdrawals by the City of Albuquerque increased from about 2,000 acre-ft/yr in 1933 to about 117,000 acre-ft/yr in 1990 (Thorn and others, 1993). Prior to 1955, most City of Albuquerque wells were located in the inner valley of the basin. The annual quantity of water pumped by the City of Albuquerque prior to 1933 was not recorded, but likely minimum and maximum quantities are well defined (Kernodle and others, 1995). Total annual withdrawals are available for 1933 to 1959 , and monthly withdrawals by well field are available from 1960 through 1987. Time of operation and production capacity of each well are available to estimate monthly withdrawals by well for 1980 to 1987 . Monthly withdrawal data by well are available beginning in 1988 .

Other municipal users of ground water include the communities of Rio Rancho, Paradise Hills, Belen, and others; Kirtland Air Force Base; and utility companies. Total ground-water withdrawal by municipal users other than the City of Albuquerque was about 21,100 acre-ft/yr in 1990 , by commercial and industrial users was about $8,300 \mathrm{acre}-\mathrm{ft} / \mathrm{yr}$, and by private domestic users was about 6,300 acre-ft/yr (Thorn and others, 1993).

\section{Evapotranspiration}

Water is evapotranspired from riparian, wetland, open water, and irrigated areas in the inner valley of the Albuquerque Basin and from upland areas not hydraulically connected to the ground-water system. Evapotranspiration in irrigated areas is accounted for in the estimates of recharge to the ground-water flow system from applied irrigation, and thus is not a ground-water discharge. The Bureau of Reclamation (1973) estimated in field studies that an average of 3 $\mathrm{ft} / \mathrm{yr}$ of water is evapotranspired by tamarisk and Russian olives, two riparian species that grow in the inner valley. Using this rate, Thorn and others (1993) estimated that evapotranspiration from riparian vegetation in the inner valley is 112,000 acre- $\mathrm{ft} / \mathrm{yr}$. 
Thorn and others assumed an evapotranspiration rate of $5 \mathrm{ft} / \mathrm{yr}$ from wetlands on the basis of studies by Blaney and others (1938), and estimated evapotranspiration from wetland areas in the inner valley to be about 13,500 acre-ft/yr. Digital data used to determine areas of the basin from which evapotranspiration occurs include GIS data bases of the U.S. Geological Survey (formerly data bases of the National Biological Survey) for 1935 and 1989 , and digital land-cover data from the Bureau of Reclamation for 1955, 1975, and 1992 (Kernodle and others, 1995).

\section{TRANSIENT GROUND-WATER FLOW MODEL}

The transient, three-dimensional numerical model of ground-water flow in the Albuquerque Basin described in this report is a modified version of the flow models described in Kernodle and others (1995) and Kernodle (1998). The model discretization has been coarsened in space and in time so that flow simulations are faster, and representation of many boundary conditions has changed. In addition, in this work six different configurations of the basin subsurface are considered, and the nonlinear-regression procedure was applied to the model with each of these subsurface configurations. Differences among the six configurations include variation in the thickness of basin deposits, whether or not a hypothesized highly permeable geologic unit is included, and whether or not the horizontal hydraulic conductivity of a fault zone in the western part of the basin is substantially reduced.

\section{Numerical Method}

Transient, three-dimensional ground-water flow through heterogenous anisotropic porous media is governed by the following equation:

$$
\frac{\partial}{\partial x}\left(K_{x x} \frac{\partial h}{\partial x}\right)+\frac{\partial}{\partial y}\left(K_{y y} \frac{\partial h}{\partial y}\right)+\frac{\partial}{\partial z}\left(K_{z z} \frac{\partial h}{\partial z}\right)-W=S_{s} \frac{\partial h}{\partial t}
$$

where

$$
x, y=\text { cartesian coordinates in the }
$$
horizontal direction $(\mathrm{L})$;

$z=$ cartesian coordinate in the vertical direction $(\mathrm{L})$; $K_{x x}, K_{y y} K_{z z}=$ hydraulic conductivity in the $\mathrm{x}, \mathrm{y}$, and $\mathrm{z}$ directions $\left(\mathrm{LT}^{-1}\right)$;

$h=$ hydraulic head $(\mathrm{L})$;

$$
\begin{aligned}
W= & \text { volumetric flux per unit } \\
& \text { volume }\left(\mathrm{T}^{-1}\right) ; \\
S_{s}= & \text { specific storage }\left(\mathrm{L}^{-1}\right) ; \text { and } \\
t= & \text { time. }
\end{aligned}
$$

The U.S. Geological Survey MODFLOW model (McDonald and Harbaugh, 1988) implements a finitedifference approximation of equation 1 . The

MODFLOW model and the preconditioned conjugate gradient solver (Hill, 1990) were used to simulate ground-water flow in the Albuquerque Basin. The hydrogeologic deposits are assumed to be isotropic in the horizontal direction but to exhibit horizontal to vertical anisotropy. The MODFLOW model of the basin was calibrated using the nonlinear regression method implemented in MODFLOWP (Hill, 1992). This method is described in the section "Model Calibration Procedure."

\section{Spatial Discretization}

Although the Albuquerque Basin is defined as the extent of Cenozoic deposits within the bounding structural uplifts, the model domain occupies a smaller volume. The eastern and western model boundaries are mostly coincident with faults thought to be significant barriers to horizontal ground-water movement (fig. 3). The model boundaries in the north and south coincide with the boundaries of the Albuquerque Basin, which are defined by mountains and uplifts (fig. 3 ). In the areal dimension, the domain is discretized into a finitedifference grid of 113 rows and 60 columns of rectangular cells (fig. 6). The azimuth of the $y$ coordinate axis of the model grid is N.17. $5^{\circ} \mathrm{E}$., and is roughly aligned with the long axis of the basin. The smallest model cells are $2,461 \mathrm{ft}$ by $2,461 \mathrm{ft}(750 \mathrm{~m}$ by $750 \mathrm{~m}$ ) and are located in the Albuquerque area, where the largest ground-water withdrawals occur and where hydrogeologic conditions have been characterized in more detail than in other parts of the basin. Cell size increases to the north, south, and west of Albuquerque; the maximum cell size is $16,404 \mathrm{ft}$ by $8,202 \mathrm{ft}(5$ kilometers $(\mathrm{km})$ by $2.5 \mathrm{~km}$ ) in the northeastern part of the basin. In the models of Kernodle and others (1995) and Kernodle (1998), the $y$-axis of the model grid was aligned with north, the smallest model cells were $656 \mathrm{ft}$ by $656 \mathrm{ft}(200 \mathrm{~m}$ by $200 \mathrm{~m})$, and the largest model cells were $3,281 \mathrm{ft}$ by $3,281 \mathrm{ft}(1 \mathrm{~km}$ by $1 \mathrm{~km})$.

In the vertical dimension, the basin thickness through which ground-water flow is simulated varies depending on the subsurface configuration. Three of 


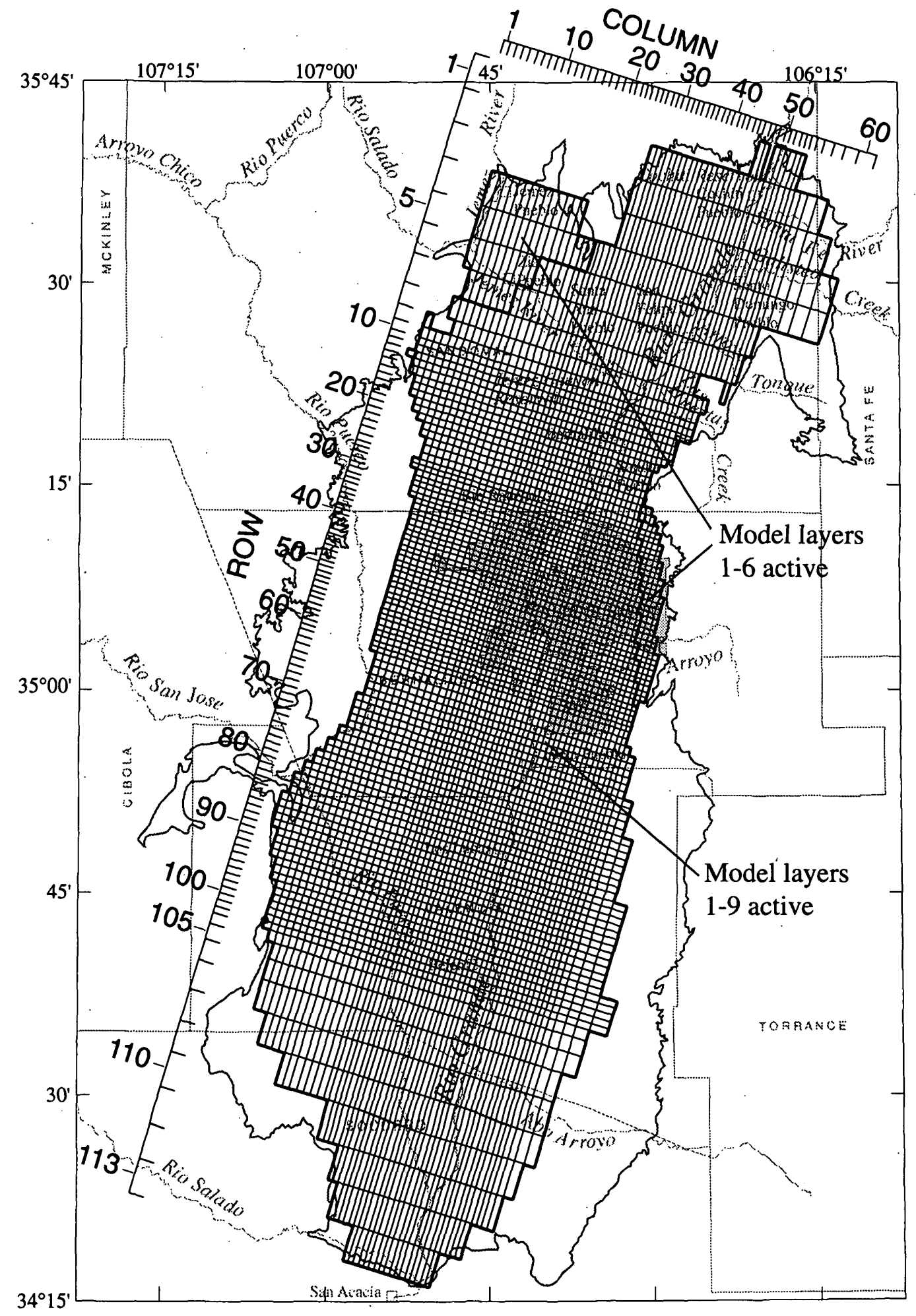

\begin{tabular}{|c|c|c|c|}
\hline & 10 & 2 & 30 MILES \\
\hline & & & \\
\hline
\end{tabular}

Figure 6. Plan view of finite-difference grid. 
the subsurface configurations assume that ground water flows through about $1,600 \mathrm{ft}$ of the uppermost Santa Fe Group and post-Santa Fe Group basin-fill deposits, and three subsurface configurations assume that ground water flows through about $5,000 \mathrm{ft}$ of the deposits. For configurations with the 1,600-ft-thick basin, the Santa Fe Group and post-Santa Fe Group basin-fill deposits are divided into six model layers, each of which has the same horizontal extent (fig. 6). The upper boundary of the model (the top of layer 1) is the water table. The bottom of layer 1 is $40 \mathrm{ft}$ below the bed of the Rio Grande, and the altitude of the bottom of layer 1 is constant in an orthogonal direction away from the trend of the inner valley (fig. 7). The thickness of layer 1 is spatially and temporally variable because of the varying position of the simulated water table, which is computed during the model simulation. Layers 2, 3, 4, 5, and 6 have constant thicknesses of 40 $\mathrm{ft}, 120 \mathrm{ft}, 200 \mathrm{ft}, 400 \mathrm{ft}$, and $800 \mathrm{ft}$, respectively. The models of Kernodle and others (1995) and Kernodle (1998) had a simulated basin thickness of about 1,800 $\mathrm{ft}$ beneath the Rio Grande, and divided the basin deposits into 11 model layers.

For subsurface configurations in which the basin deposits are 5,000 ft thick, the deposits are divided into nine model layers. The horizontal extent and vertical discretization of the upper six layers are the same as those for the subsurface configurations with a $1,600-\mathrm{ft}$ basin thickness. Layers 7, 8, and 9 have constant thicknesses of $1,000 \mathrm{ft}, 1,100 \mathrm{ft}$, and $1,300 \mathrm{ft}$, respectively. In the central part of the basin, the horizontal extent of these three lower layers (fig. 6) is delineated on the basis of basin cross sections in Hawley and Haase (1992) and Hawley and others (1995), which suggest that the width of the modeled part of the basin does not narrow appreciably with depth. For purposes of constructing model layers 7,8 , and 9 , it is assumed that this interpretation applies to the southern part of the basin as well. In the northwestern part, layers 7, 8, and 9 are absent at the basin margins on the basis of cross sections in Kelley (1977). Layers 7, 8, and 9 are present in the entire northeastern part of the model on the basis of gravity data that suggest the basin deposits are thick in this region (Heywood, 1992).

Limitations of this coarser spatial discretization are that, compared with the models of Kernodle and others (1995) and Kernodle (1998), there is less detailed spatial representation of basin hydraulic properties, hydrologic boundary conditions such as drains and canals in the inner valley, and ground-water withdrawals. Compared to the previous models, this results in less detailed simulation of the distribution of hydraulic heads, of the interaction of ground water and surface water in the inner valley, and of well interference. The coarser discretization also results in greater discretization error, such as that associated with misrepresenting boundaries between hydrogeologic units.

\section{Temporal Discretization}

Ground-water flow in the Albuquerque Basin is simulated from 1900 to March 1995. Steady-state conditions are simulated in the year 1900 and represent basin conditions prior to significant development of ground-water resources. The transient simulation from 1901 to March 1995 is divided into 29 stress periods. Boundary and internal stresses in the flow model are constant for the duration of a stress period. For 1901 through 1960, stress periods are 5 years. The time period 1961 through 1963 is simulated as a 3-year stress period. From 1964 through 1993, stress periods are 2 years. The period 1994 through March 1995 is simulated as one stress period of 15 months. With this temporal discretization, seasonal effects are not simulated. The important features of the flow-system dynamics are assumed to be reasonably represented with this discretization. This assumption is supported by results of the model of Kernodle and others (1995), which had a total of 61 stress periods and during 1980 to 1994 had stress periods corresponding to summer and winter seasons. Seasonal changes in specified pumpage were simulated, and evapotranspiration was simulated only during the summer months. These seasonal variations in specified conditions did not result in significant annual variation in the simulated basin budget components (Kernodle and others, 1995, fig. 37).

\section{Boundary Conditions}

Boundary conditions include no flow on the bottom of the model domain, no flow and specified flow on the sides of the model domain, and specified flow and head-dependent flow on the top of the model domain. For each boundary condition, an associated parameter is considered for inclusion in the set of parameters to be estimated by the nonlinear-regression 


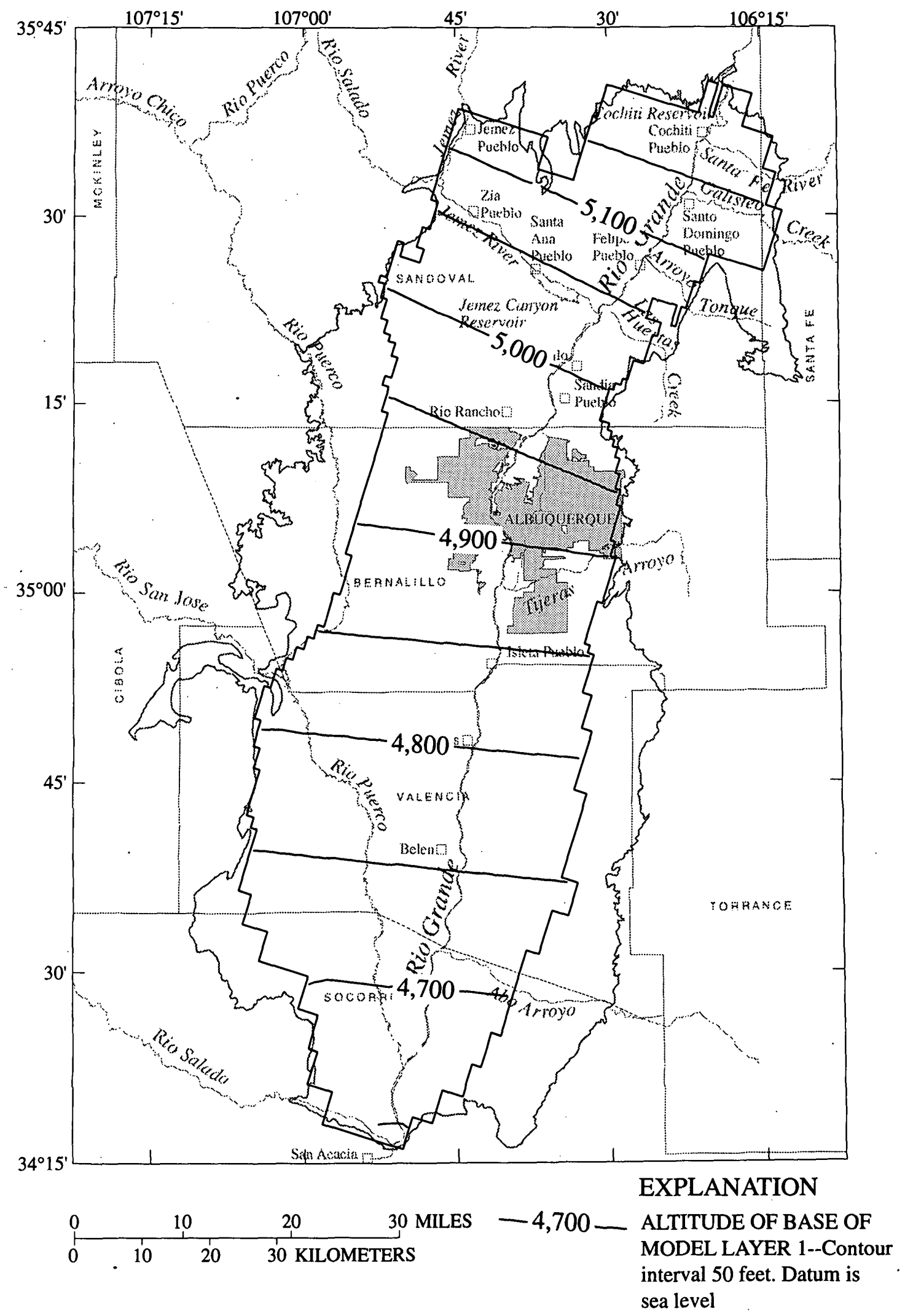

Figure 7. Altitude of base of model layer 1. 
procedure that was used to calibrate the flow model, and an initial value for the parameter is assigned. Initial parameter and model-input values are generally equal to those specified in the models of Kernodle and others (1995) and Kernodle (1998). For parameters included in the estimated set, optimal parameter values were computed by the nonlinear-regression method.

\section{Head-Dependent Boundaries}

\section{Interaction of Ground Water and Surface Water}

Head-dependent boundaries are implemented in the inner valley of the Albuquerque Basin to represent the interaction of the Rio Grande, canals, drains, and Cochiti Reservoir with the ground-water flow system. This interaction is simulated using the river package of MODFLOW (McDonald and Harbaugh, 1988). In the river package, flow between a surface-water body and the underlying cell of the ground-water flow model is a function of the altitude of the stage of the surface-water body; the simulated hydraulic head in the cell; the length and width of the surface-water body in the cell; and the altitude, vertical hydraulic conductivity, and thickness of the bed of the surface-water body. For the river, drains, and canals, the bed vertical hydraulic conductivity is the parameter considered for inclusion in the set of parameters to be estimated by the nonlinear-regression procedure. None of the parameters associated with Cochiti Reservoir are considered for inclusion in the estimated set because this reservoir is a fairly small feature compared to the area occupied by other inner-valley surface-water bodies. The initial value of bed vertical hydraulic conductivity for the river, canals, and drains and the value specified for Cochiti Reservoir are shown in table 1 , along with the stage altitude, bed altitude, and bed thickness specified in the model for each of the surfacewater bodies. The altitude control for the canal and drain boundaries is updated from that used in the models of Kernodle and others (1995) and Kernodle (1998). The previous models used DEMs that were inaccurate in some areas of the basin. In the model presented here, land and water surface altitudes of boundary conditions are obtained from the more accurate U.S. Geological Survey 1:24,000-scale topographic maps.

The area of the river, drain, and canal channels in each cell varies both spatially and temporally. This variation is included in the model boundary conditions in a limited manner. The area of the river and the location of canals and drains are available for 1935 , $1955,1975,1989$, and 1992 from GIS coverages of the hydrography of the surface-water bodies. The positions of the surface-water bodies are constant during several model stress periods spanning each of the years for which a GIS coverage is available. The canal widths are assumed to be 10,5 , or $2 \mathrm{ft}$, respectively, for canals, laterals, and ditches, and the drain widths are assumed to be $5 \mathrm{ft}$ (Kernodle and others, 1995).

Table 1. Model input values for head-dependent boundaries simulated with the river package of MODFLOW [Bed thickness in feet; bed vertical hydraulic conductivity in feet per day; ft, feet; LSA, land surface altitude; ,-- not considered for inclusion in set of estimated parameters]

\begin{tabular}{|c|c|c|c|c|c|}
\hline \multirow[b]{2}{*}{ Boundary } & \multirow[b]{2}{*}{ Altitude of stage equal to } & \multirow[b]{2}{*}{ Altitude of bed equal to } & \multirow[b]{2}{*}{$\begin{array}{c}\text { Bed } \\
\text { thickness }\end{array}$} & \multicolumn{2}{|c|}{$\begin{array}{l}\text { Bed vertical hydraulic } \\
\text { conductivity }\end{array}$} \\
\hline & & & & Parameter & $\begin{array}{l}\text { Initial } \\
\text { value }\end{array}$ \\
\hline Rio Grande & Water surface altitude & $4 \mathrm{ft}$ below Rio Grande stage & 1.0 & $\mathrm{~K}_{\mathrm{RB}}$ & 0.50 \\
\hline Canals & $3 \mathrm{ft}$ above altitude of canal bed & $2 \mathrm{ft}$ above LSA adjacent to canal & 1.0 & $\mathrm{~K}_{\mathrm{CB}}$ & 0.15 \\
\hline Drains & Altitude of drain bed & $3 \mathrm{ft}$ below LSA adjacent to drain & 1.0 & $\mathrm{~K}_{\mathrm{DB}}$ & 1.00 \\
\hline $\begin{array}{l}\text { Cochiti } \\
\text { Reservoir }\end{array}$ & Mean annual water level & LSA from Digital Elevation Models & 1.0 & -- & 0.15 \\
\hline
\end{tabular}


Although at some locations and times drain water recharges the ground-water system, Kernodle and others (1995) and Kernodle (1998) simulated these surface-water bodies using the drain package of MODFLOW, which allows drains to receive groundwater discharge but does not allow drain water to recharge the ground-water system. In the model presented here, the drains are treated in the same conceptual manner, but the interaction of the drains with the ground-water flow system is simulated with the river package so that the observed net recharge to the flow system from the Rio Grande and riverside drains can be used in the nonlinear-regression calibration procedure. The version of MODFLOWP (Hill, 1992) used in this study requires that the simulated equivalent of a head-dependent flow observation involve cells from only one MODFLOW package. To ensure that the drains function only as discharge boundaries when simulated with the river package, the drain stage altitudes are specified to be equal to the drain bottom altitudes (table 1).

\section{Evapotranspiration}

Evapotranspiration from riparian lands in the inner valley is simulated using the evapotranspiration package of MODFLOW. In the models of Kernodle and others (1995) and Kernodle (1998), land surface altitudes were obtained from DEMs, whereas in the model presented here, they are obtained from the more accurate U.S. Geological Survey 1:24,000-scale topographic maps. The maximum evapotranspiration rate $\left(E T_{\max }\right)$, which is the simulated rate when the water-table altitude is at land surface, is the parameter considered for inclusion in the set of parameters to be estimated by regression. The initial value of $\mathrm{ET}_{\max }$ for each model cell is $2.6 \mathrm{ft} / \mathrm{yr}$ times the proportion of the cell area that is covered by riparian vegetation or wetlands. The evapotranspiration rate is zero when the water-table altitude is below the extinction depth, which is specified as $20 \mathrm{ft}$ below land surface. When the simulated water table is between land surface and the extinction depth, the computed evapotranspiration rate is a linear function of the water-table position.

\section{Specified Inflows}

Recharge of precipitation and stream water is simulated as a specified flux to the uppermost active cell of the model, using the recharge package of MODFLOW. This recharge is divided into eight geographic zones, each of which generally corresponds to one basin-boundary segment, a group of basinboundary segments, or a stream along which recharge has been estimated by a water-budget method (figs. 5 and 8). These eight zones are: (1) recharge to the northeastern part of the basin, including tributary recharge along the Santa Fe River and Galisteo Creek, (2) tributary recharge along the Jemez River, (3) mountain-front recharge along the Sandia Mountains and tributary recharge along Tijeras Arroyo, (4) recharge along the west margin of the basin, which represents recharge along the upper reach of the Rio Puerco (fig. 5), (5) mountain-front recharge along the Manzanita and Manzano Mountains, (6) tributary recharge along the Rio Puerco, (7) recharge to the southeastern part of the basin, including tributary recharge along Abo Arroyo, and (8) tributary recharge along the Rio Salado. Tributary recharge along the Jemez River includes the reach containing Jemez Canyon Reservoir (fig. 2). The effect of transient reservoir storage on ground-water recharge is not simulated.

Initial total volumetric recharge rates for most streams and basin-boundary segments are equal to the long-term average estimates made by the water-budget method (fig. 5). The initial recharge rates along the Jemez River and Rio Salado are each about one-half of the rates estimated by the water-budget method, on the basis of modifications made by Kernodle and others (1995). An initial recharge rate along the Hagan Embayment was assumed. Within each of the recharge zones, the recharge rates on a cell-by-cell basis are spatially variable, depending on, for example, the surface area of the stream that occupies a particular model cell (Kernodle and others, 1995). In the regression procedure used to calibrate the model, this spatial variability of recharge within a zone is fixed. For each recharge zone, the parameter included in the set considered for estimation by regression is a "recharge multiplier," which is a factor by which the recharge rate in each cell of the recharge zone is multiplied (table 2). The initial value for each multiplier is 1.0. Initial values for total annual recharge in each recharge zone are shown in table 2.

In the models of Kernodle and others (1995) and Kernodle (1998), mountain-front and tributary recharge varied temporally in proportion to the departure from long-term average precipitation. Multiplicative factors ranged from 0.63 to 1.50 . This temporal variation in recharge resulted in temporal 


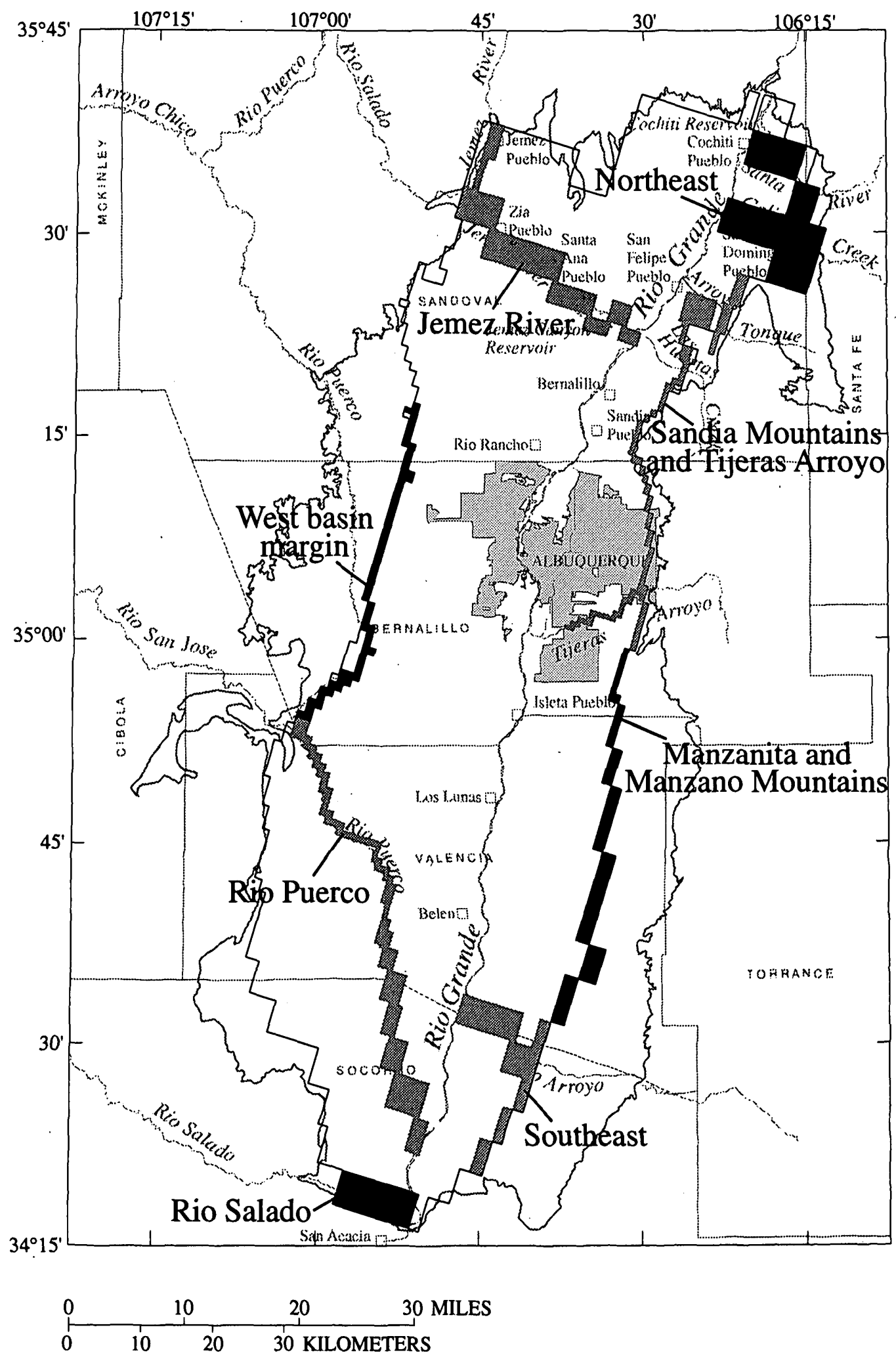

Figure 8. Locations of recharge zones in the ground-water flow model. 
Table 2. Recharge zone parameters and initial values

[Recharge in acre-feet per year; recharge multiplier dimensionless]

\begin{tabular}{lclc}
\hline & $\begin{array}{c}\text { Initial total } \\
\text { annual } \\
\text { Recharge zone }\end{array}$ & \multicolumn{2}{c}{ Recharge multiplier } \\
\cline { 4 - 4 } \cline { 4 - 4 } recharge & & Parameter & Initial value \\
\hline Northeast & 7,700 & $\mathrm{RM}_{\mathrm{NE}}$ & 1.0 \\
Jemez River & 12,300 & $\mathrm{RM}_{\mathrm{Jemez}}$ & 1.0 \\
Sandia Mountains and Tijeras Arroyo & 29,600 & $\mathrm{RM}_{\mathrm{S} \& \mathrm{~T}}$ & 1.0 \\
West basin margin & 4,700 & $\mathrm{RM}_{\text {West }}$ & 1.0 \\
Manzanita and Manzano Mountains & 23,100 & $\mathrm{RM}_{\mathrm{M} \& \mathrm{M}}$ & 1.0 \\
Rio Puerco & 10,800 & $\mathrm{RM}_{\mathrm{Puerco}}$ & 1.0 \\
Southeast & 19,000 & $\mathrm{RM}_{\mathrm{SE}}$ & 1.0 \\
Rio Salado & 7,200 & $\mathrm{RM}_{\text {Salado }}$ & 1.0 \\
\hline
\end{tabular}

variation in the simulated quantity of water released from aquifer storage, but resulted in very little temporal variation in other simulated budget components (Kernodle and others, 1995, figs. 36 and 37). In the model presented in this report, mountain-front and tributary recharge is assumed to be constant in time because the version of MODFLOWP used does not support the scaling of estimated recharge by a known, temporally varying multiplicative factor.

The depths at which ground water flows into the Albuquerque Basin across the basin boundaries are uncertain. Underflow is simulated using the well package of MODFLOW as a specified flow into layer 3 of the model, which corresponds to a similar depth at which underflow was simulated in the models of Kernodle and others (1995) and Kernodle (1998). The boundary segments and the initial quantities of total flow for each segment are shown in figure 5. Within each of the segments, flows on a cell-by-cell basis are spatially variable, depending on the size of the cell to which the boundary flow is assigned, so that the inflow per unit boundary length is constant for the segment. Inflows from the San Juan Basin, the Sierra Lucero and Ladron Peak region, and the part of the Española Basin east of the Rio Grande are not considered for inclusion in the set of parameters to be estimated by the nonlinear-regression procedure used to calibrate the model because these fluxes are small relative to other water-budget components of the model. Inflow from the Jemez Mountains and the western part of the Española Basin is larger than the other inflows and is considered for inclusion in the set of estimated model inputs. In the regression, the spatial variability of the inflow along this segment is fixed, and the parameter included in the set considered for estimation by the regression procedure is an "inflow multiplier," $\mathrm{QM}_{\text {North }}$, which is a factor by which the flow into each cell is multiplied. The initial value of $\mathrm{QM}_{\mathrm{North}}$ is 1.0.

Seepage to the ground-water flow system from applied irrigation is represented as a specified flow to the uppermost active model cell, using the recharge package of MODFLOW. Initial irrigation seepage is computed assuming that 1 acre-ft per irrigated acre per year recharges the ground-water flow system. GIS data bases are used to determine the change in simulated irrigated areas with time. The parameter considered for inclusion in the set estimated by the regression procedure is an "irrigation recharge multiplier" $\left(\mathrm{RM}_{\text {Irrig }}\right)$ with an initial value of 1.0. This parameter is a factor by which the spatially variable initial irrigation seepage is multiplied.

Seepage to the ground-water flow system from septic field discharge also is represented as an applied flow to the uppermost active model cell using the MODFLOW recharge package. The parameter considered for inclusion in the set estimated by the regression is a "septic recharge multiplier" $\left(\mathrm{RM}_{\text {Septic }}\right)$ with an initial value of 1.0. This parameter is a factor by which the spatially variable initial septic seepage is multiplied. 


\section{Specified Outflows}

Ground-water withdrawals are simulated with the well package of MODFLOW. The simulated withdrawals are somewhat different from those in the models of Kernodle and others (1995) and Kernodle (1998) because errors in pumpage data were corrected during development of the model presented here. During 1901 through 1945, pumping only by the City of Albuquerque; the University of New Mexico; and the Atchison, Topeka, and Santa Fe Railway yard is simulated. Simulated withdrawal by Kirtland Air Force Base begins in 1946, and simulated withdrawal by other municipalities, businesses, and institutions begins in the 1950's. Withdrawal from private domestic wells is simulated beginning in 1961. Additional detail regarding the spatial and temporal distribution of withdrawals is given by Kernodle and others (1995, p. 22-25). Because of the longer stress periods in the flow model reported here, simulated withdrawals are averaged over longer time periods than in the models of Kernodle and others (1995) and Kernodle (1998).

\section{Hydraulic Properties}

Hydraulic properties of the basin fill are represented in the flow model by the distribution of hydraulic conductivity and of storage parameters throughout the model domain. The hydraulicconductivity distribution differs somewhat among the six subsurface configurations of the basin that are considered, whereas the representation of storage properties is the same among the six configurations. The hydraulic-conductivity distribution includes the representation of normal faults located within the Albuquerque Basin (fig. 3). Most of these faults are treated in a similar manner among the six subsurface configurations, except for special treatment of one fault zone in two of the configurations.

\section{Faults}

Faults are generally treated in the same manner as in the models of Kernodle and others (1995) and Kernodle (1998). In most cells containing a fault, the horizontal hydraulic conductivity is reduced to equal 0.2 times the horizontal hydraulic conductivity of the hydrogeologic unit that occupies the cell. The vertical hydraulic conductivity of cells containing faults is unaffected by the presence of the fault.
The horizontal hydraulic conductivity of cells containing the part of Cat Mesa Fault north of about latitude $34^{\circ} 48^{\prime}$ (fig. 3) is set to $0.004 \mathrm{ft} /$ day. This part of Cat Mesa Fault appears to be a greater barrier to flow than many other faults in the basin because hydraulichead measurements on opposite sides of this part of the fault indicate that head is about $130 \mathrm{ft}$ higher on the west side of the fault than on its east side (fig. 4). In the ground-water flow model, a very low fault hydraulic conductivity is required for the simulated head difference to approach this large measured head difference. The hydraulic conductivity of this part of Cat Mesa Fault was not considered for inclusion in the set of parameters to be estimated by the regression procedure because although it has a large effect on simulated heads at a few wells, this fault section is a fairly small feature on the basin scale.

The horizontal hydraulic conductivity of cells containing the northern part of the West Sandia Fault, located in the piedmont-slope deposits west of the eastern model boundary (fig. 3 ), is specified as 0.4 $\mathrm{ft} /$ day, about 25 times lower than the initial horizontal hydraulic conductivity of the piedmont-slope deposits. Near the northern part of this fault, observed hydraulic heads are approximately $600 \mathrm{ft}$ higher on the east side of the fault than on the west side (this difference is not shown in figure 4 because ground-water levels from wells east of the West Sandia Fault were not used in constructing the figure). Specifying a fault hydraulic conductivity of $0.4 \mathrm{ft} /$ day results in a head difference of about $100 \mathrm{ft}$ across the West Sandia Fault. A smaller fault hydraulic conductivity was not specified because further reduction of this hydraulic conductivity results in a maximum simulated head difference of about 200 $\mathrm{ft}$ at the pair of measurement locations on opposite sides of the fault but unrealistically large simulated hydraulic-head values in the northernmost model cells located on the east side of the fault. Refinement of the flow model grid in the vicinity of the West Sandia Fault may be needed for improved simulation of hydraulic heads east of the fault. The hydraulic conductivity of West Sandia Fault was not considered for inclusion in the set of parameters to be estimated by regression because (1) it was likely that the regression would reduce the fault hydraulic conductivity and produce highly unrealistic simulated heads as discussed above, and (2) although the fault has a large effect on simulated heads at a few wells, it is a fairly small feature on the basin scale. 


\section{Subsurface Configurations}

Six different representations of the hydrogeologic structure of the Albuquerque Basin are considered in the ground-water flow model. The nonlinear-regression method was applied to the model with each of these subsurface configurations to estimate the optimal parameters for each. The configurations are designed to test the effects of (1) varying the basin thickness through which groundwater flow is simulated, (2) including in the model a hypothesized hydrogeologic unit with high hydraulic conductivity in the western part of the basin, and (3) reducing the horizontal hydraulic conductivity of a fault zone in the western part of the basin. The features that differ among the six subsurface configurations are summarized in table 3.

In each subsurface configuration, basin deposits are divided into hydraulic-conductivity zones that generally correspond to the likely or assumed locations of basin hydrogeologic units. The horizontal hydraulic conductivities of most of these zones are parameters considered for inclusion in the set estimated by the regression and are assigned initial parameter values. In each configuration, the vertical hydraulic conductivity of each zone is calculated from its horizontal hydraulic conductivity and the vertical anisotropy of the basin deposits $\left(A_{V}\right)$, defined as the ratio of horizontal to vertical hydraulic conductivity. The single parameter $A_{V}$ applies to all model layers. It is considered for inclusion in the set estimated by the regression and has an initial value of 200, which is that used in the models of Kernodle and others (1995) and Kernodle (1998).
In subsurface configuration 1, the basin thickness beneath the Rio Grande is $1,600 \mathrm{ft}$, and the six-model-layer vertical discretization is used. The division of the Santa Fe Group and post-Santa Fe Group deposits into hydraulic-conductivity zones is similar to the zonation in the ground-water flow model of Kernodle (1998). Nine hydraulic-conductivity zones represent Santa Fe Group deposits (fig. 9). These include the piedmont-slope deposits of the upper part of the Santa Fe Group (USF-P zone), the undivided upper part of the Santa Fe Group (USF1 zone), the undivided axial-channel deposits of the upper part of the Santa Fe Group (USF2 zone), two subunits of the very coarse axial-channel deposits in the Albuquerque area (USF3 and USF4 zones), the undivided middle part of the Santa Fe Group (MSF zone), the undivided lower part of the Santa Fe Group (LSF zone), the Zia Sand of the lower part of the Santa Fe Group (LSF-Z zone), and the Cochiti Formation of the lower part of the Santa Fe Group (LSF-C zone).

On the basis of recent geologic mapping (D. Sawyer, Geologist, U.S. Geological Survey, oral commun., 1996), the USF2 zone has been extended into the northern part of the basin in layers 1 through 3 (fig. 9). In the model of Kernodle (1998), this unit terminated just south of the confluence of the Jemez River and Rio Grande. In addition, on the basis of cross sections in Hawley and others (1995), the MSF zone in the central and southern parts of model layer 6 extends farther to the west than in the model of Kernodle (1998).

Table 3. Summary of subsurface configurations

[Basin thickness in feet; $\mathrm{K}$, hydraulic conductivity]

\begin{tabular}{cccc}
\hline $\begin{array}{c}\text { Subsurface } \\
\text { configuration }\end{array}$ & $\begin{array}{c}\text { Basin thickness } \\
\text { beneath the } \\
\text { Rio Grande }\end{array}$ & $\begin{array}{c}\text { West basin high-K } \\
\text { zone included? }\end{array}$ & $\begin{array}{c}\text { Horizontal K of } \\
\text { fault zone in west } \\
\text { basin reduced? }\end{array}$ \\
\hline 1 & 1,600 & No & No \\
2 & 5,000 & No & No \\
3 & 1,600 & Yes & No \\
4 & 5,000 & Yes & No \\
5 & 1,600 & No & Yes \\
6 & 5,000 & No & Yes \\
\hline
\end{tabular}




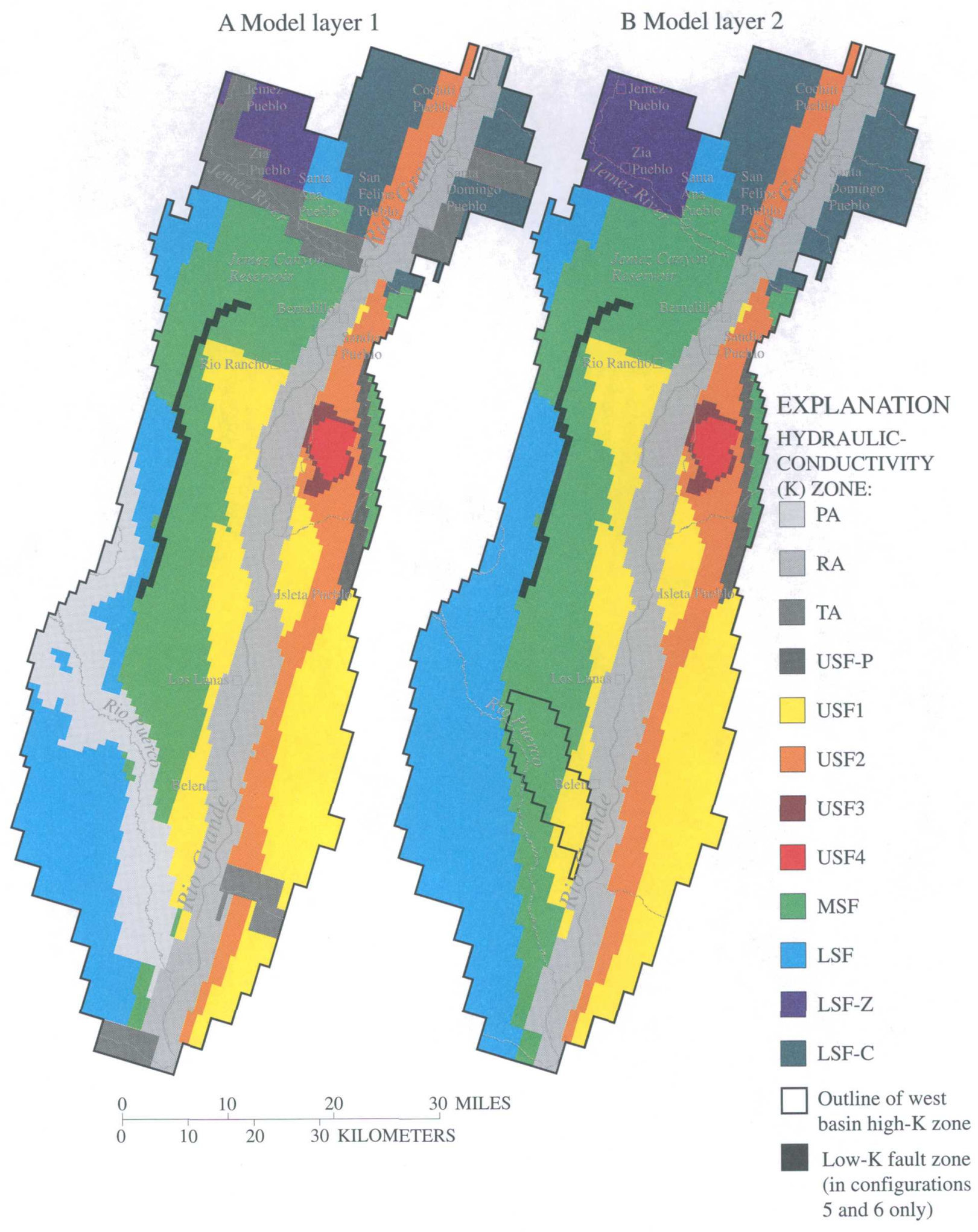

Figure 9. Hydraulic-conductivity zones in the ground-water flow model. In subsurface configurations 3 and 4 , the west basin high-K zone replaces the hydraulic-conductivity zones inside the shape outlined in the western part of the Albuquerque Basin. 


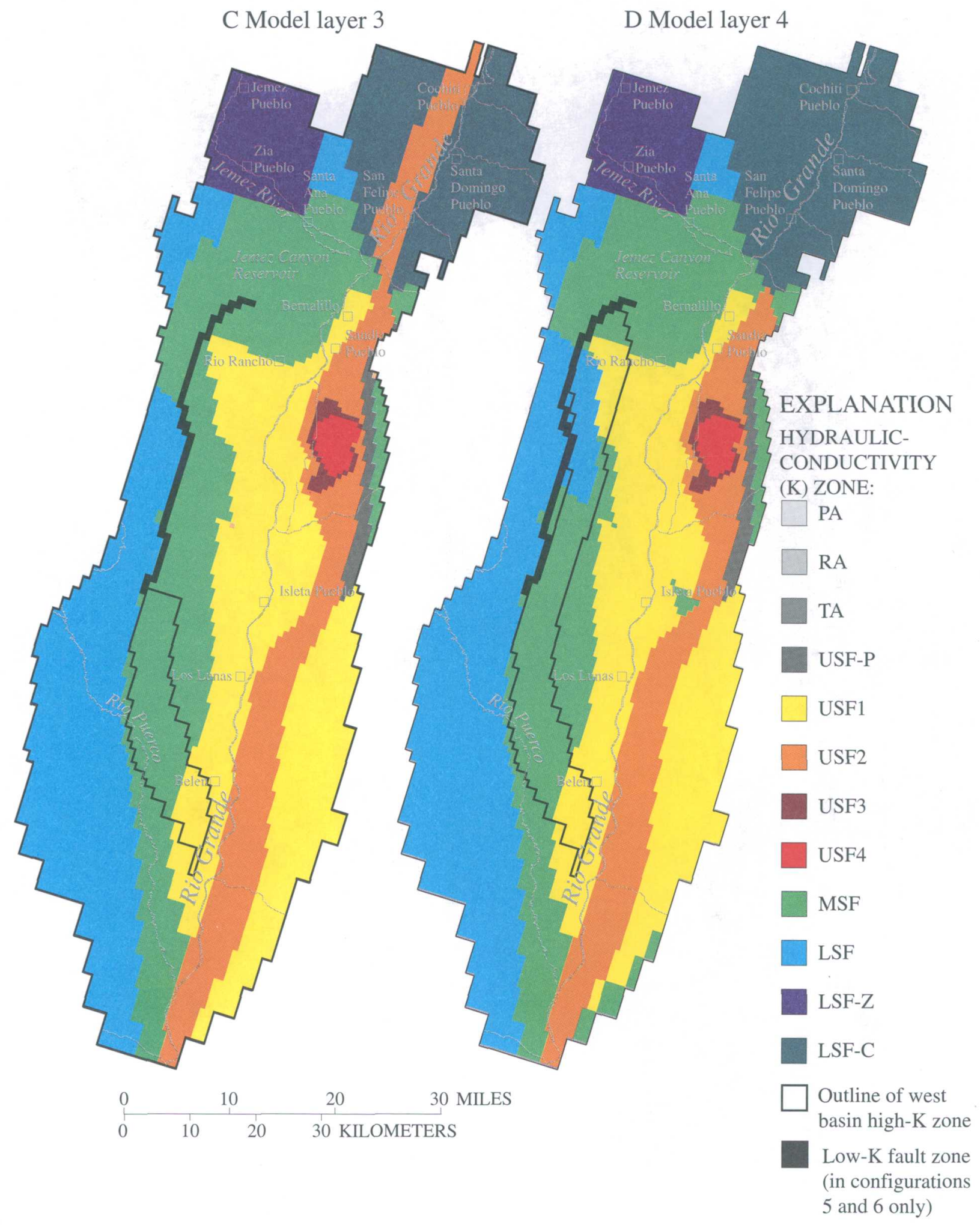

Figure 9 (Continued). Hydraulic-conductivity zones in the ground-water flow model. In subsurface configurations 3 and 4 , the west basin high-K zone replaces the hydraulic-conductivity zones inside the shape outlined in the western part of the Albuquerque Basin. 


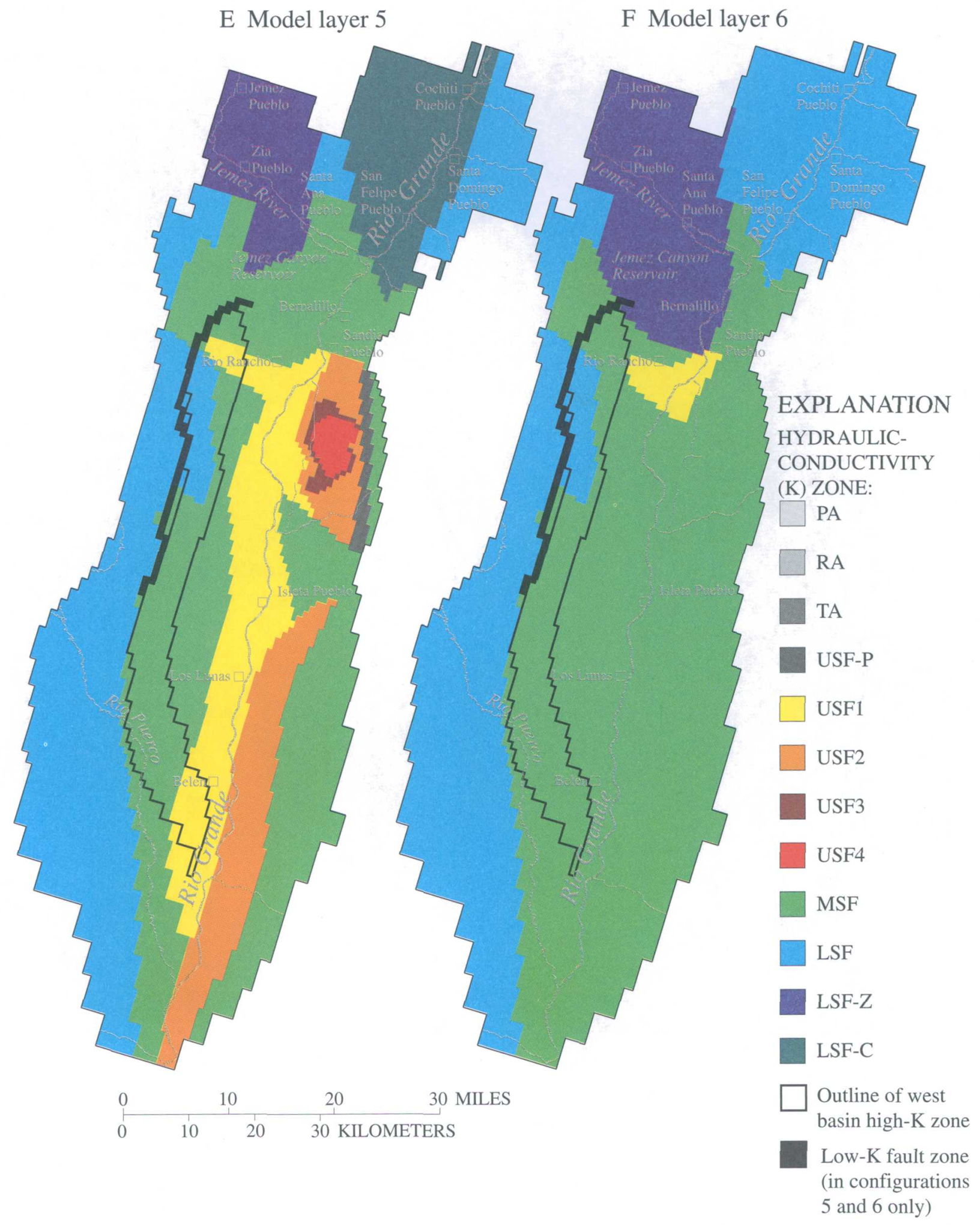

Figure 9 (Continued). Hydraulic-conductivity zones in the ground-water flow model. In subsurface configurations 3 and 4 , the west basin high- $K$ zone replaces the hydraulic-conductivity zones inside the shape outlined in the western part of the Albuquerque Basin. 


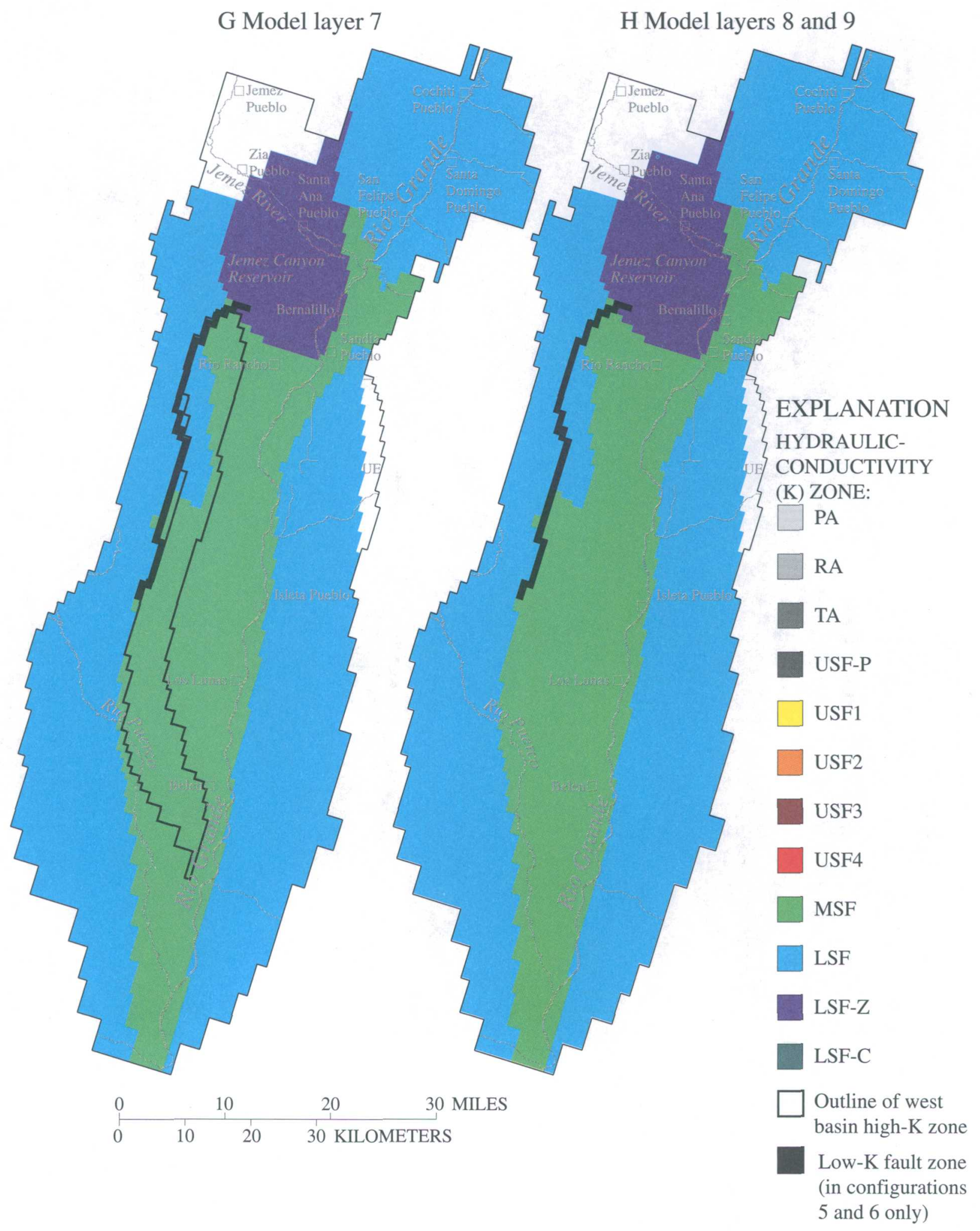

Figure 9 (Concluded). Hydraulic-conductivity zones in the ground-water flow model. In subsurface configurations 3 and 4 , the west basin high- $K$ zone replaces the hydraulic-conductivity zones inside the shape outlined in the western part of the Albuquerque Basin. 
The post-Santa Fe Group units in subsurface configuration 1 are divided into three hydraulicconductivity zones present in model layers 1 and 2 (fig. 9): Rio Grande alluvium (RA zone), Rio Puerco alluvium (PA zone), and tributary alluvium (TA zone) along the Jemez River, Santa Fe River, Galisteo Creek, Abo Arroyo, and Rio Salado. This division of postSanta Fe Group deposits differs slightly from that in the model of Kernodle (1998) in that a part of the Rio Grande alluvium just south of Albuquerque that might contain a higher percentage of clay than the remainder of the Rio Grande alluvium is not represented separately from the undivided river alluvium. The reasons for this change are (1) it is unclear from borehole data whether this clay is horizontally continuous and (2) initial model runs indicated that in the clay-rich area, at clusters of piezometers with screened intervals at different depths, simulated hydraulic heads are closer to observed heads when the vertical hydraulic conductivity of the clay-rich zone is the same as that of the undivided Rio Grande alluvium.

The horizontal hydraulic conductivity of each hydrogeologic unit in subsurface configuration 1 is a parameter considered for inclusion in the set to be estimated by regression. The initial horizontal hydraulic conductivity of each zone is shown in table 4 .

In subsurface configuration 2 , the simulated basin thickness beneath the Rio Grande is $5,000 \mathrm{ft}$ and the nine-model-layer vertical discretization is used. The delineation of hydrogeologic units in the upper six layers is the same as that in configuration 1 (fig. 9A-F). In the central part of the basin, cross sections in Hawley and Haase (1992) and Hawley and others (1995) are the basis for estimating locations of hydrogeologic units in layers 7,8 , and 9 (fig. 9G-H). The boundary between the MSF and LSF zones is extended along faults into the southern part of the basin. In the northern basin, boundaries between hydrogeologic units are generally extended into the lower layers from their positions in layer 6, with the exception that the USF1 zone is assumed to pinch out and thus is not present in layers 7,8 , and 9 . The hydraulic conductivity of each hydrogeologic unit in subsurface configuration 2 is a parameter considered for inclusion in the set to be estimated by regression.

Table 4. Hydraulic-conductivity parameters and initial values

[Hydraulic conductivity in feet per day; $\mathrm{K}$, hydraulic conductivity]

\begin{tabular}{lll}
\hline & \multicolumn{2}{c}{$\begin{array}{c}\text { Horizontal hydraulic } \\
\text { conductivity }\end{array}$} \\
\cline { 2 - 3 } Hydraulic-conductivity zone & Parameter $^{\text {Initial value }}$ \\
\hline Rio Grande alluvium, undifferentiated (RA) & $\mathrm{K}_{\mathrm{RA}}$ & 40 \\
Rio Puerco alluvium (PA) & $\mathrm{K}_{\mathrm{PA}}$ & 20 \\
Alluvium, other tributaries to the Rio Grande (TA) & $\mathrm{K}_{\mathrm{TA}}$ & 10 \\
Upper Santa Fe, undifferentiated (USF1) & $\mathrm{K}_{\mathrm{USF}}$ & 10 \\
Upper Santa Fe, undivided axial-channel deposits (USF2) & $\mathrm{K}_{\mathrm{USF} 2}$ & 30 \\
Upper Santa Fe, coarse axial-channel deposits (USF3) & $\mathrm{K}_{\mathrm{USF} 3}$ & 50 \\
Upper Santa Fe, very coarse axial-channel deposits (USF4) & $\mathrm{K}_{\mathrm{USF}}$ & 70 \\
Upper Santa Fe, piedmont-slope deposits (USF-P) & $\mathrm{K}_{\mathrm{USF}-\mathrm{P}}$ & 10 \\
$\begin{array}{l}\text { Middle Santa Fe, undifferentiated (MSF) } \\
\text { Lower Santa Fe, undifferentiated (LSF) }\end{array}$ & $\mathrm{K}_{\mathrm{MSF}}$ & 4 \\
Lower Santa Fe, Zia Sand (LSF-Z) & $\mathrm{K}_{\mathrm{LSF}}$ & 2 \\
Lower Santa Fe, Cochiti Formation (LSF-C) & $\mathrm{K}_{\mathrm{LSF}-\mathrm{Z}}$ & 10 \\
West basin high-K zone (WB) & $\mathrm{K}_{\mathrm{LSF}-\mathrm{C}}$ & 4 \\
\hline
\end{tabular}


Subsurface configuration 3 is the same as subsurface configuration 1 except that it contains an additional hydraulic-conductivity zone on the west side of the Rio Grande in model layers 2 through 6 (fig. 9). This zone, termed the west basin high-K zone, is included to examine the hypothesis that in this part of the basin there may be a geologic deposit with higher permeability than that of adjacent deposits that results in a "trough" in the configuration of the water table.

This ground-water trough is inferred from hydraulichead measurements reported by Meeks (1949), Bjorklund and Maxwell (1961), and Titus (1961, 1963) (Thorn and others, 1993, fig. 27). In the 1940's through early 1960 's, there was little ground-water withdrawal in this area of the Albuquerque Basin and there likely is little or no recharge from precipitation over the broad area of the central basin west of Albuquerque.

Therefore, the ground-water trough is likely to be indicative of subsurface geologic conditions. The ground-water trough in the central-western part of the basin is evident from the contours of ground-water levels that represent winter 1994-95 conditions (fig. 4). The trough is located west of about longitude $106^{\circ} 45^{\prime}$, where there is little ground-water withdrawal and where the horizontal hydraulic gradient is relatively flat compared with the gradient to the west and north.

One possible explanation for the ground-water trough is that in the central-western part of the basin there might be subsurface material with higher permeability than that of adjacent areas. Very permeable material was encountered in the borehole drilled for piezometer WM1A (see fig. 12) at a depth of about 1,150 ft below land surface (Wilkins, 1987). Drilling of the borehole was terminated at a depth of about $1,200 \mathrm{ft}$ below land surface because of loss of drilling fluids into the formation, but samples of the formation were not recovered. In addition to the surface volcanic features in the western part of the basin (fig. 3) that lie above the ground-water trough, aeromagnetic surveys show features at the WM1A site that could be interpreted as buried cinder cones (Grauch and Sawyer, 1997). However, these features do not appear to be extensive or interconnected within the area of the ground-water trough and the role, if any, that these buried cinder cones play in the formation of the trough is unknown.

Although there is no geologic evidence of a continuous volume of highly permeable material in the subsurface of the western part of the basin, the inclusion of the west basin high-K zone in subsurface configuration 3 is designed to test the degree of permeability needed to reproduce the ground-water trough given the geologic framework currently implemented in the model, and to help assess whether the presence of subsurface material with permeability that is greater than that of adjacent areas might be a possible explanation for the ground-water trough. The horizontal extent of the west basin high- $\mathrm{K}$ zone is delineated primarily on the basis of the location of the ground-water trough in the early 1960's (Thorn and others, 1993, fig. 27). Because very permeable material was encountered in piezometer WM1 A at a depth corresponding to layer 4 of the flow model, in the central part of the basin the zone is present only in layers 4 through 6 (fig. 9D-F). The southern end of the zone extends upward into layers 2 and 3 of the model and abuts the RA zone in layer 2 (fig. 9B-C). This connection of the downgradient part of the west basin high-K zone to a hydrologic boundary is necessary for the zone to have a draining effect on the ground-water flow system. Here, the west basin high-K zone in subsurface configuration 3 is connected to the RA zone (fig. 9), which has a much higher initial hydraulic conductivity than the MSF and LSF zones that mostly bound the west basin high-K zone.

The hydraulic conductivity of each hydrogeologic unit in subsurface configuration 3 is a parameter considered for inclusion in the set to be estimated by regression (table 4 ). The initial hydraulic conductivity of the west basin high-K zone is 200 $\mathrm{ft} /$ day, which in initial model simulations was a value large enough to cause development of a trough in the distribution of simulated hydraulic heads in the western part of the basin. However, this hydraulic-conductivity value is not supported at present by the sparse information on permeability in the west-central part of the basin.

In subsurface configuration 4 , the basin thickness and vertical discretization are the same as in configuration 2 , and the west basin high- $\mathrm{K}$ zone is included. The delineation of hydrogeologic units in the upper six layers is the same as that in configuration 3 . The west basin high- $\mathrm{K}$ zone is simulated as extending into layer 7 (fig. 9G), but not into layers 8 and 9; thus, the representation of the hydrogeologic units in layers 8 and 9 is the same as that in configuration 2 . The hydraulic conductivity of each hydrogeologic unit in subsurface configuration 4 is a parameter considered for inclusion in the set to be estimated by regression. 
Subsurface configurations 5 and 6 are designed to test whether faults with very low hydraulic conductivity might play a role in the formation of the ground-water trough in the western part of the basin. In subsurface configuration 5 the basin thickness and delineation of hydrogeologic units are the same as in configuration 1, and in configuration 6 the basin thickness and hydrogeologic units are the same as in configuration 2. However, in both configurations 5 and 6 the hydraulic conductivity of the West Atrisco Fault (fig. 3) and of some cells north and east of this fault are reduced to $0.004 \mathrm{ft} /$ day. The group of cells with this low hydraulic conductivity is termed the low- $\mathrm{K}$ fault zone (fig. 9). The West Atrisco Fault extends north from Cat Mesa Fault; the processes that resulted in the northern part of Cat Mesa Fault being a significant barrier to flow might have occurred along West Atrisco Fault as well. Reduction of the hydraulic conductivity of the West Atrisco Fault creates a partial barrier to ground-water flow from the west into the area of the ground-water trough. Reduction of the hydraulic conductivity of cells to the north and east of West Atrisco Fault is necessary to create a low-hydraulicconductivity restriction to ground water flowing from the north into the area of the ground-water trough. Initial model simulations indicated that reducing the hydraulic conductivity of the West Atrisco Fault alone (as mapped in fig. 3) did not result in a substantial enough reduction in simulated hydraulic heads. Some of the cells in the low-K fault zone that are north and east of the West Atrisco Fault contain fault segments mapped in figure 3, whereas other cells do not. More recent basin geologic maps (Hawley, 1996, pl. 2) show some faults in this part of the basin trending to the northeast, and the shape of the northern part of the low$\mathrm{K}$ fault zone shown in figure 9 is consistent with the trend of such faults on these recent geologic maps. Although its position may not exactly coincide with mapped faults, inclusion of the low- $\mathrm{K}$ fault zone is designed to test the general concept that faults with low hydraulic conductivity might restrict flow into the area of the ground-water trough, and if so, might be a partial cause for the low ground-water levels in the western part of the basin.

\section{Storage Parameters}

The specific yield (Sy) and the specific storage (Ss) are assumed to be uniform over the model domain. Both parameters are considered for inclusion in the set of estimated parameters. The initial value of Sy is 0.15 and the initial value of Ss is $2 \times 10^{-6}$ per foot, which are the values used in the ground-water flow models of Kernodle and others (1995) and Kernodle (1998).

\section{MODEL CALIBRATION PROCEDURE}

\section{Nonlinear Least-Squares Regression Method}

The ground-water flow model was calibrated by the nonlinear least-squares regression method formulated by Cooley and Naff (1990) and implemented for MODFLOW in the computer code MODFLOWP by Hill (1992). As part of this study, the MODFLOWP code was modified so that it properly calculates flows and sensitivities for the case of multiple reaches simulated with the MODFLOW river package in a single model cell. These changes are described in the appendix.

In the regression procedure, optimal parameter values are estimated by minimizing the squared weighted differences between observed and simulated quantities:

$$
S(\boldsymbol{b})=\sum_{i=1}^{n}\left[w_{i}^{1 / 2} e_{i}\right]^{2}
$$

$$
\text { where } \quad \begin{aligned}
\quad \boldsymbol{b}= & \begin{array}{c}
\text { vector of parameters to be } \\
\text { estimated; }
\end{array} \\
n= & \text { number of measurements; } \\
w_{i}{ }^{1 / 2}= & \text { weight on difference } e_{i} ; \text { and } \\
e_{i}= & \text { residual (difference between } \\
& \text { observed and simulated value) } \\
& \text { for measurement } i .
\end{aligned}
$$

The residual $e_{i}$ is equal to the difference between an observed $\left(y_{i}\right)$ and simulated $\left(\hat{y}_{i}(\boldsymbol{b})\right)$ quantity. In this study $y_{i}$ represents a measured hydraulic head or flow, whereas $\hat{y}_{i}$ represents the simulated equivalent of $y_{i}$. The minimization of equation 2 is performed by the modified Gauss-Newton method (Cooley and Naff, 1990; Hill, 1992).

The weight on a difference between an observed and simulated value reflects the importance of matching the particular observation, and usually is related to the accuracy of the measurement. In this study $w_{i}$ is generally calculated as the inverse of the estimated variance of the measurement error, following 
procedures suggested by Hill $(1992,1998)$. By using this method, highly accurate measurements, which have small variance, have relatively large weights, whereas less accurate measurements, with large variance, have relatively small weights. Furthermore, the weighted differences $w_{i}^{1 / 2} e_{i}$ are dimensionless numbers; therefore, squared weighted differences for quantities with different units, such as hydraulic head and flow, can be summed in the objective function $S(b)$. When assessing measurement error to determine the weights, estimating the standard deviation of the measurement error instead of its variance is often more intuitive. This standard deviation can be specified in MODFLOWP, and the code then calculates the variance and $w_{i}$.

In the process of minimizing equation 2 , the regression procedure computes the sensitivity of simulated head or flow $\hat{y}_{i}$ at observation location $i$ to each model parameter $b_{j}$. These sensitivities, $\partial \hat{y}_{i} / \partial b_{j}$, are a measure of the change in simulated head or flow resulting from a small change in the parameter value. In terms of the regression, these sensitivities indicate how much information a particular observation provides toward estimating a particular parameter. The amount of information all observations provide toward estimating a single parameter can be expressed by a summary statistic, the composite scaled sensitivity (CSS). The CSS for parameter $j$ is expressed as:

$$
C S S_{j}=\left\{\frac{\sum_{i=1}^{n} w_{i}\left(\frac{\partial \hat{y}_{i}}{\partial b_{j}} b_{j}\right)^{2}}{n}\right\}^{\frac{1}{2}}
$$

Because this measure is scaled by the parameter value $b_{j}$, its value for different parameters can be compared and used to choose the set of parameters to estimate in the regression procedure. Parameters with larger values of CSS are those to which the data as a whole are more sensitive and therefore more likely to be estimated by the regression. Parameters with smaller values of CSS are those to which the data as a whole are less sensitive. If these parameters are included in the set of parameters to be estimated, the regression likely will not converge to a set of optimal parameter values.

\section{Representation of Model Layers During Calibration}

In 1992, the water table in the Albuquerque area was as much as $160 \mathrm{ft}$ below steady-state water levels (Thorn and others, 1993, fig. 32). With the six- or ninelayer vertical discretization used in the model, groundwater withdrawals will result in dewatering in parts of layers 1, 2, and 3 if simulated drawdowns are $160 \mathrm{ft}$ in the Albuquerque area. The most accurate method of simulating this transient dewatering in MODFLOW requires representing layer 1 as unconfined and layers 2 and 3 as confined/unconfined. Cells in layers simulated as confined/unconfined may be fully or partially saturated or may completely dewater. The transmissivity of these cells is computed as the product of saturated thickness and hydraulic conductivity of the cell. If the cell is fully saturated, the confined storage coefficient is used to compute changes in storage in the cell. If the cell is partially saturated, the specific yield is used to compute changes in storage. Confined/ unconfined layers are commonly referred to as convertible layers.

The version of MODFLOWP used in this study does not support estimation of parameters for models of transient ground-water flow with convertible layers. Therefore, during calibration of the Albuquerque Basin flow model, layer 1 was represented as unconfined and all lower layers were represented as confined. This representation results in inaccurate transmissivities and storage terms computed for cells in layers 2 and 3 in parts of the model where dewatering occurs in these layers. To examine the effect of these inaccuracies, a comparison was made of model simulations with (1) layer 1 represented as unconfined and layers 2 and 3 represented as confined and (2) layer 1 represented as unconfined and layers 2 and 3 represented as convertible. This comparison revealed that simulated hydraulic head in the two different representations can differ by tens of feet in the area of greatest groundwater withdrawals, beginning in the early 1980's. Differences are dependent on model parameter values, but generally increase with time and are greater in layers 2 and 3 than in the lower model layers. To minimize the effect on model calibration of the inaccurate simulated hydraulic head in parts of the model domain, hydraulic-head data used for model calibration were selected only from locations where and for times at which simulated head in the model without convertible layers differs by less than $5 \mathrm{ft}$ from simulated head in the model with convertible layers. 


\section{Calibration Data Set}

The data set used in the regression procedure includes 802 hydraulic-head observations and one flow observation. The hydraulic-head data selected provide broad spatial and temporal coverage of basin conditions. The flow observation is the net recharge from the Rio Grande and the riverside drains to the ground-water system over the gaged reach between the Paseo del Norte and Rio Bravo Bridges (fig. 2).

\section{Hydraulic-Head Observations}

The 802 hydraulic-head observations include those during three different time periods from wells throughout the Albuquerque Basin and those at several times from 17 wells and 14 piezometer nests. The hydraulic-head observations that were excluded from the calibration data set because of differences between model simulations with layers 2 and 3 represented as confined and as convertible are located in the Albuquerque area and were made as early as 1981 .

The three time periods with measurements from wells throughout the basin are 1950 through 1960 , 1992, and 1994. Within each of these three time periods, the data are divided into two groups: measurements from shallow wells and measurements from deep wells. Figure 10 shows the distribution of shallow and deep wells for which head observations are available for each of the three periods. Shallow wells are defined here as wells for which the bottom of the screened interval is in model layer 1,2 , or 3 . Most of the shallow wells have short screened intervals that lie entirely within a single model layer, although a few have longer screened intervals that span more than one model layer. Some shallow wells have a recorded bottom depth but an unknown screen location. For these wells, the screened interval was assumed to extend from the bottom of the well to a point $20 \mathrm{ft}$ above the well bottom. Many wells outside the Albuquerque area have no information on well depth or screened interval location. The hydraulic-head observations for these wells are important because they provide information in areas of sparse data. Because it is unlikely that these are major production wells, they are assumed to be shallow wells used for domestic or livestock supply whose well screen lies near the water table.

Deep wells are defined here as wells for which the bottom of the screened interval is in model layer 4 , 5 , or 6 . All deep wells with known screened intervals that are used in the calibration have screens that span two or more model layers. Therefore, for wells with a known bottom altitude in model layers 4,5 , or 6 but an unknown screen location, the screen was assumed to span the layer containing the well bottom and the overlying layer. Most deep wells lie in the central part of the Albuquerque Basin, in and around the city of Albuquerque (fig. 10). No wells penetrate layers 7, 8, or 9 in the subsurface configurations with a $5,000-\mathrm{ft}$ basin thickness.

The 17 wells with transient hydraulic-head data, called "hydrograph wells" (fig. 11), include wells B, C, D, E, H, I, J, K, L, N, O, Q, R, S, T, V, and W for which observed and simulated hydraulic heads are presented in Kernodle (1998). All these wells have known screened intervals except wells B, E, Q, and W. Well B, near San Felipe Pueblo, has an unknown depth but is retained in the calibration data set because it is located in the northeastern part of the basin where data are sparse. Its screened interval is assumed to be in model layer 3. Wells $\mathrm{E}, \mathrm{Q}$, and $\mathrm{W}$ are windmill wells near Sandia and Isleta Pueblos. They have a recorded well depth, and the screen is assumed to span a $40-\mathrm{ft}$ interval above the bottom of the well. Only two hydraulic-head observations from well $\mathrm{K}$ and one hydraulic-head observation from well $\mathrm{N}$ are included in the calibration data set because the differences between simulated hydraulic head in the confined-layer model representation and the convertible-layer representation are greater than $5 \mathrm{ft}$ at later times in these wells. They are retained in the set of hydrograph wells for consistency with previous reports on ground-water flow models of the Albuquerque Basin.

The 14 piezometer nests (figs. 11 and 12) each have two to four known screened intervals at different depths and provide data on vertical variation of hydraulic head. Several of these piezometers are clustered in the inner valley near the Rio Grande. Piezometer nests PDN1, PDN2, and WM3 are near the Paseo del Norte Bridge; piezometer nests MON1, MON2, and MON5 are near or along Montaño Boulevard; and piezometer nests RB1, RB3, RB4, and RB5 are near the Rio Bravo Bridge. Two piezometer nests, WM1A and WM2, are located on the West Mesa several miles west of the Rio Grande. The middle screened interval of WM2 is well F shown in Kernodle (1998), and the shallow interval of WM1A is well M shown in Kernodle (1998). Two piezometer nests, ZP and SAP, are located in the northern part of the basin near Zia and Santa Ana Pueblos (fig. 11). 


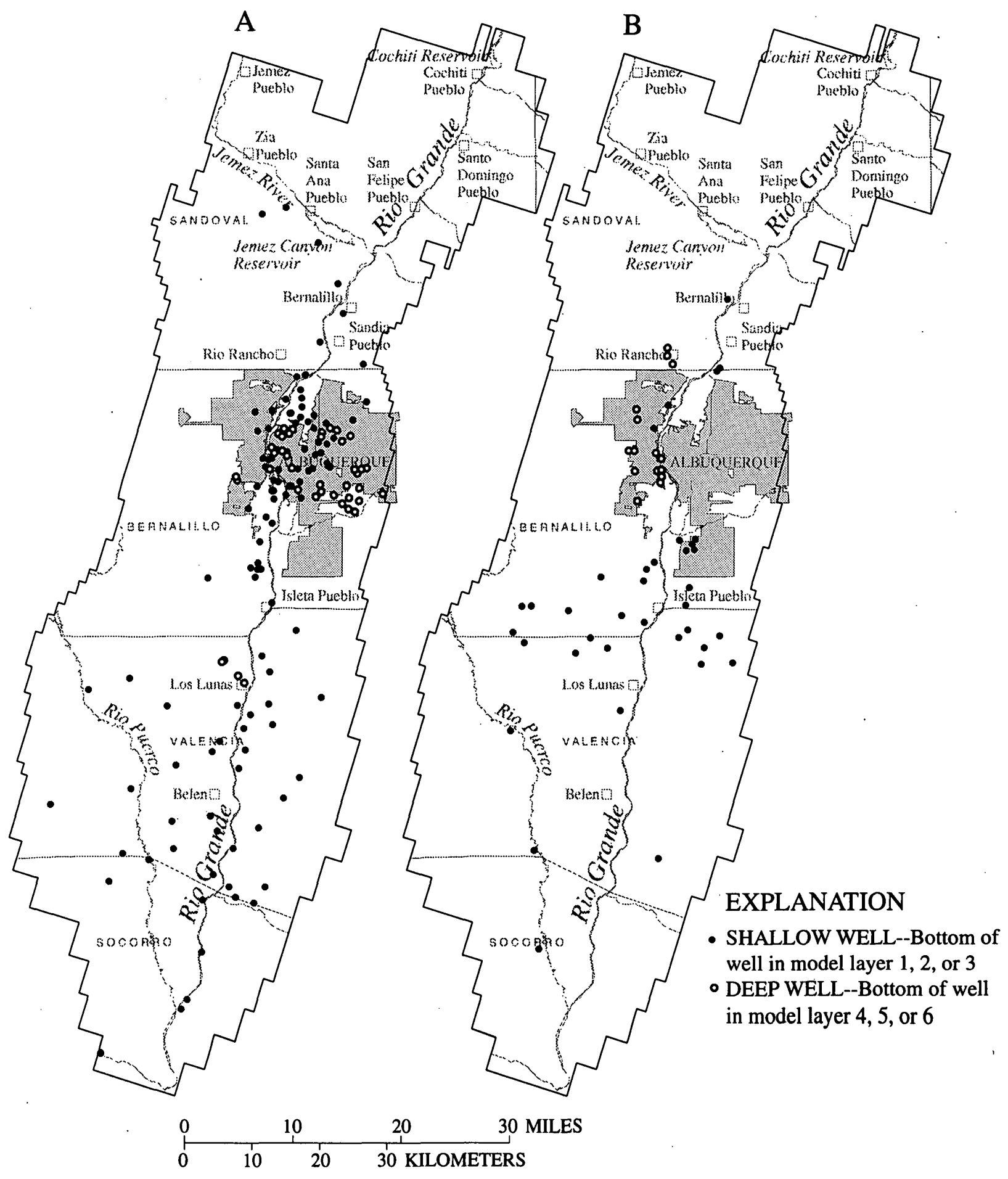

Figure 10. Locations of wells for which hydraulic-head measurements for (A) the 1950's, (B) 1992, and (C) 1994 are included in the calibration data set. 


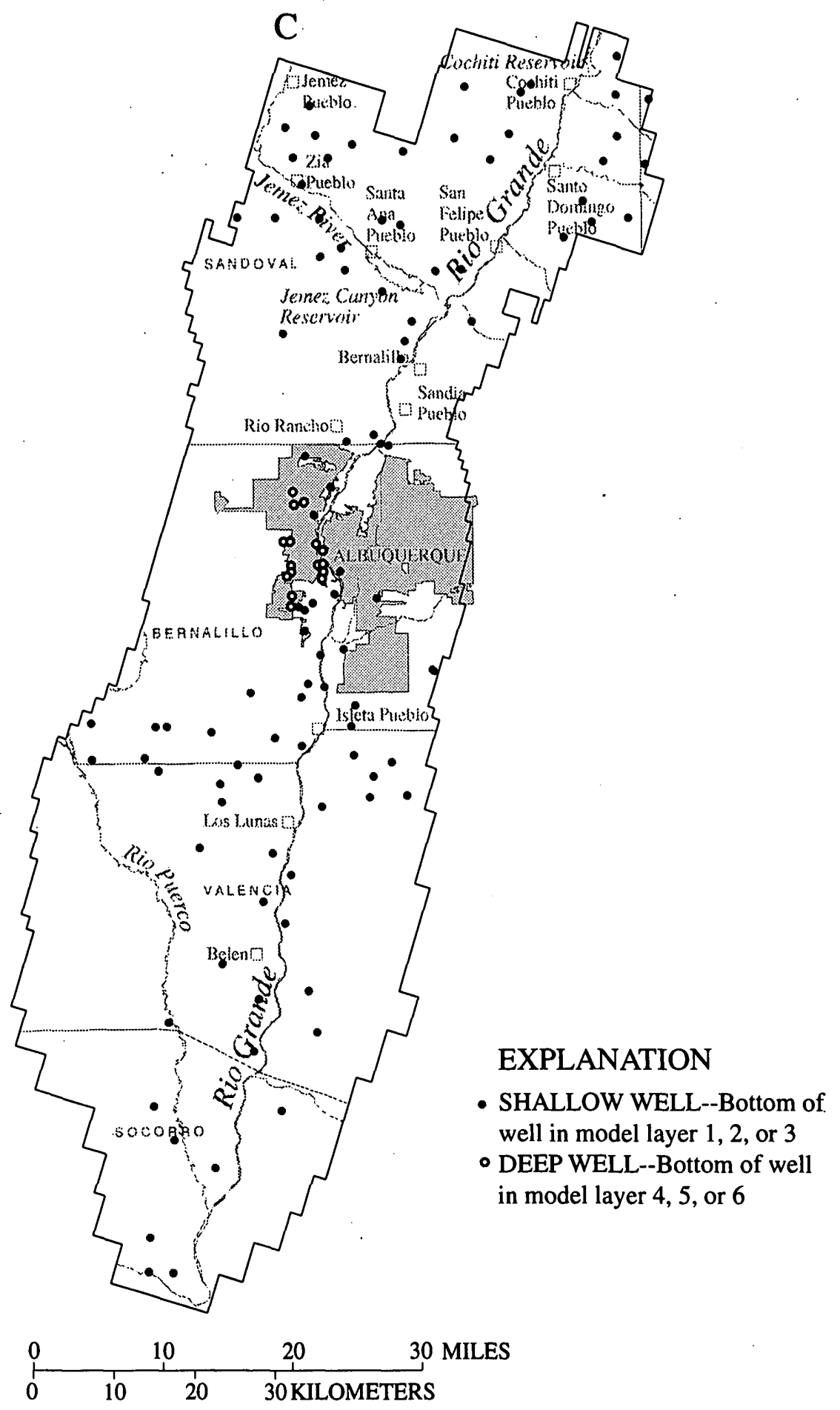

Figure 10 (Concluded). Locations of wells for which hydraulic-head measurements for (A) the 1950's, (B) 1992, and (C) 1994 are included in the calibration data set. 


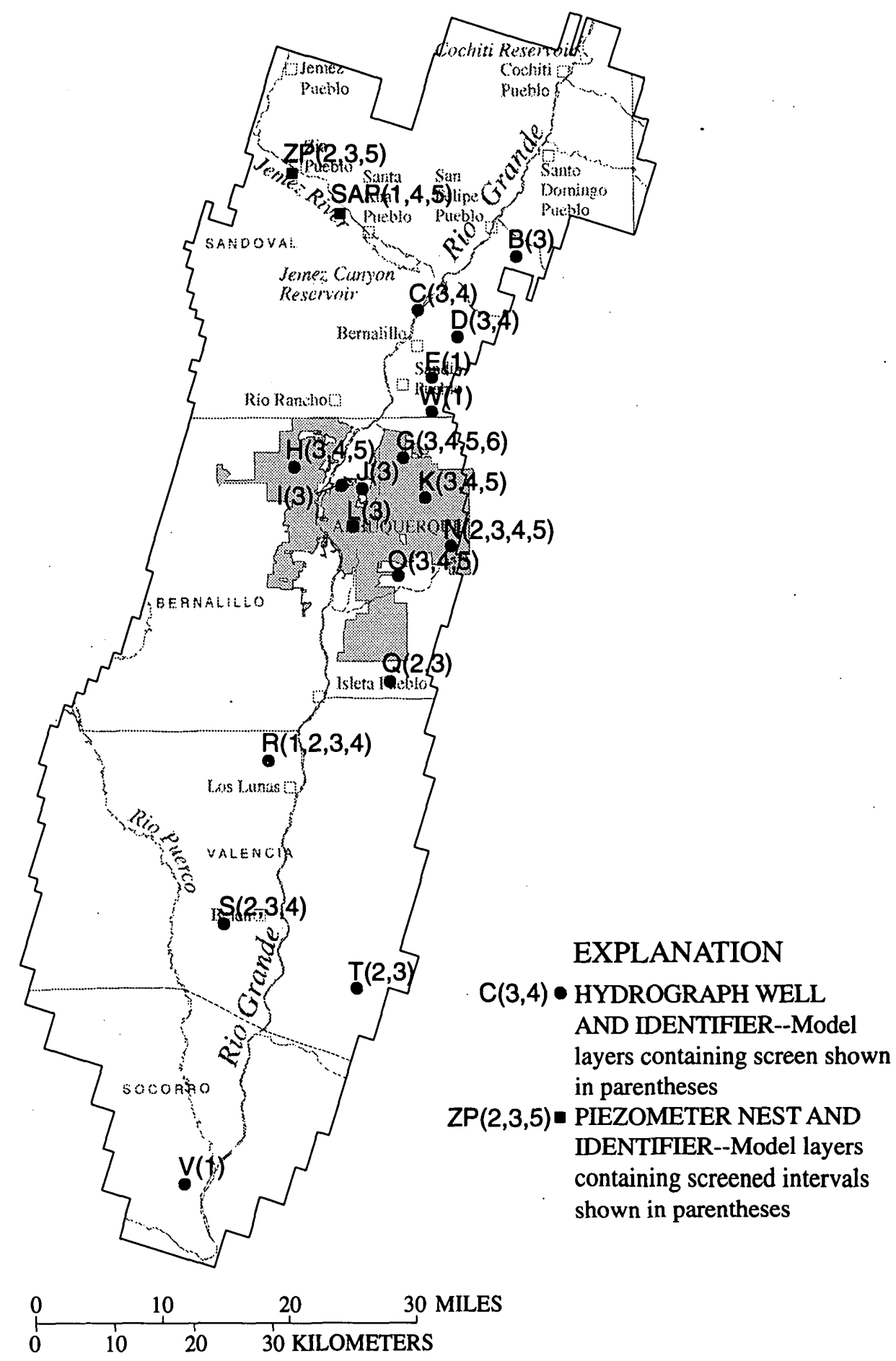

Figure 11. Locations of hydrograph wells and piezometers ZP and SAP. 

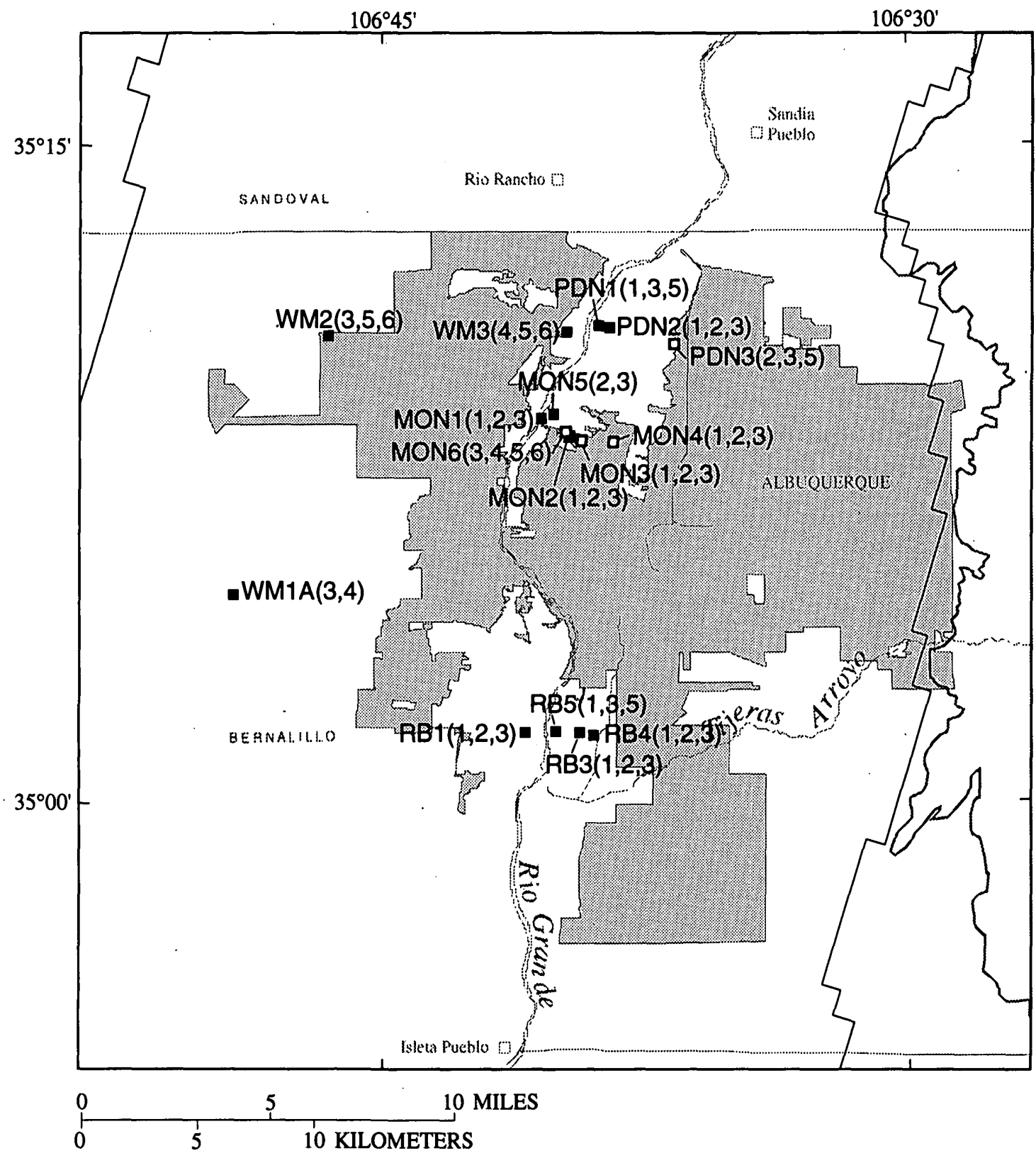

\section{EXPLANATION}

RB1 $(1,2,3)$ PIEZOMETER NEST IDENTIFIER--Model layers containing screened intervals shown in parentheses

- PIEZOMETER NEST--Location for which hydraulic-head data are included in calibration data set

- PIEZOMETER NEST--Location for which hydraulic-head data are not included in calibration data set

Figure 12. Locations of piezometer nests in the Albuquerque area. 
Hydraulic heads were measured at various time intervals at the hydrograph wells and piezometer nests. For some wells and piezometer nests, monthly measurements are available for some time periods. Because the model presented in this report has stress periods that are a minimum of 15 months in length, however, monthly and seasonal effects exhibited in the data cannot be reproduced by the model. Therefore, a maximum of one measurement per year for each of the hydrograph wells and screened intervals of the piezometer nests was included in the calibration data set. The hydraulic-head measurement included was that which appeared to represent the mean hydraulic head in the well for the year. The time at which hydraulic heads are representative of the mean annual level varies depending on the areal location of the well or piezometer, its proximity to the Rio Grande, and the depth of its screened interval, and can also vary from year to year. Generally, the hydraulic-head measurements included in the calibration data set were made during late spring or early summer or during the fall because these times typically lie between the times of seasonal high and low water levels.

Two hydraulic-head measurements between West Sandia Fault and the eastern boundary of the model were used only in a qualitative manner and were not included in the calibration data set. As discussed, these data suggest that the West Sandia Fault is tightly cemented, and thus prompted the reduction of the hydraulic conductivity of the northern part of this fault in the flow model. When these two head observations were included in the regression, however, an improved fit of simulated head to these data was achieved primarily by adjusting the hydraulic conductivity of the middle part of the Santa Fe Group, which is the hydrogeologic unit between West Sandia Fault and the east model boundary (figs. 3 and 9). Simulated heads at these data locations are highly sensitive to $\mathrm{K}_{\mathrm{MSF}}$; thus head measurements at these locations strongly affect the estimate of $\mathrm{K}_{\mathrm{MSF}}$. It is just as likely, however, that the fault hydraulic conductivity should be adjusted to achieve the better fit, but this fault property is not included in the regression. Therefore the head observations between the West Sandia Fault and the eastern boundary of the model were removed from the calibration data set so that they would not unduly affect the estimate of $\mathrm{K}_{\mathrm{MSF}}$.

\section{Flow Observation}

The flow observation used in the regression procedure is the median $(29,000 \mathrm{acre}-\mathrm{ft} / \mathrm{yr})$ of the 15 most reliable measurements of net flow from the Rio Grande channel and riverside drains to the groundwater flow system between the Paseo del Norte and Rio Bravo gaging stations during November through February of 1989 through 1995 (discussed in the section "Interaction with Ground-Water Flow System"). For model calibration purposes, this observation is assumed to occur in March 1995. Because the temporal discretization in the model is such that seasonal effects of hydrologic conditions are not simulated, the flow observation is compared to a simulated flow that represents average conditions during the final stress period in the model, which is January 1994 through March 1995. Flow between the inner-valley surface-water bodies and the groundwater system during March through October is very difficult to reliably measure because irrigation diversions and evapotranspiration occur during these months (J. Veenhuis, Hydrologist, U.S. Geological Survey, oral commun., 1997). Thus, average flow during the winter months is assumed to be reasonably representative of the average annual net recharge from the river and riverside drains to the ground-water system.

The simulated net flow from the river and drains to the ground-water system over the gaged reach is larger in model simulations with layers 2 and 3 represented as confined (the representation used in the regression) than in the more accurate model simulation with layers 2 and 3 represented as convertible. Despite this discrepancy, the flow observation is retained in the calibration data set. In most regression runs, the resulting simulated flow over the gaged reach is larger than the observed flow over this reach. In subsequent model simulations with layers 2 and 3 represented as convertible and with parameter values equal to the optimal parameter estimates from the regression, the simulated flow is smaller and is thus a better match to the observed flow than in the estimation runs.

\section{Weights}

In theory, weights on the observations used in the regression procedure can be calculated from estimates of the variance or standard deviation of measurement error. To estimate these standard deviations, the measurement errors can be assumed to have a normal distribution, and a 95-percent confidence interval for 
the measurement can be constructed. The 95-percent confidence interval spans a range equal to the measurement \pm 1.96 times the standard deviation (Draper and Smith, 1981, p. 94). Therefore, the standard deviation equals the 95-percent confidence interval divided by about 4.0. This approach is generally followed to calculate weights for observations in the calibration data set.

Most hydraulic-head data used in this study were collected from wells whose measuring points have not been accurately established with surveying equipment. The altitude of such wells typically is estimated by locating the well on a topographic map. Most U.S. Geological Survey 1:24,000-scale topographic maps of areas within the Albuquerque Basin have a contour interval of 10 or $20 \mathrm{ft}$. The difference between the true altitude of the well and that estimated from a topographic map is assumed to differ by no more than plus or minus one-half of the map contour interval 95 percent of the time. This estimated error results in an estimated standard deviation of measurement error of $2.5 \mathrm{ft}$ for hydraulic-head observations from wells located on maps with a $10-\mathrm{ft}$ contour interval and an estimated standard deviation of measurement error of 5 $\mathrm{ft}$ for hydraulic-head observations from wells located on maps with a 20 -ft contour interval.

For wells with unknown screened intervals, there is additional measurement error associated with the uncertainty of the depth of the measured hydraulic head. The magnitude of this error is not known. For purposes of calculating weights, the true hydraulic head associated with the assigned depth is assumed to be within $\pm 5 \mathrm{ft}$ of the measured head 95 percent of the time. This component of measurement error is added to that associated with the uncertainty in measuring-point altitudes.

Most of the deep wells have long screened intervals that span as much as several hundred feet of aquifer thickness, and are located in areas of the basin where vertical hydraulic-head gradients are steep because of large ground-water withdrawals. At these wells, the contributing proportion of hydraulic head at different depths to the measured hydraulic head is uncertain. The magnitude of this measurement error is unknown but is likely to be larger than that associated with an unknown screened interval depth in the shallow wells because of the large vertical hydraulic gradients in most deep wells. For purposes of calculating the weights, this measurement error is assumed to be $\pm 15 \mathrm{ft}$. This component of measurement error is added to that associated with the uncertainty in measuring-point altitudes.

The measuring points for all the piezometers shown in figure 12 have been accurately established by field survey, and the locations of the piezometers' screened intervals are known. Thus, the standard deviations of measurement error for these piezometer data were initially specified to be smaller than those for other hydraulic-head observations. However, with large weights on these data, the regression procedure had difficulty converging, and changed the parameter values such that two to five model parameters for each of the subsurface configurations were unreasonable. The estimate of $A_{V}$ was unreasonable for most of the configurations. This regression behavior may be related to the overly simplified representation of vertical anisotropy as uniform in the flow model. Simulated heads at the piezometers are highly sensitive to vertical anisotropy, and thus when given large weights, the piezometer data strongly affect the estimate of this parameter. To resolve the problem of several unreasonable parameter estimates, the standard deviations of measurement error for the piezometer data were increased to equal $2.5 \mathrm{ft}$. In effect, by increasing these standard deviations of measurement error, some model error is accounted for in the weighting.

For the ZP and SAP piezometers, measuringpoint altitudes have been established by field survey but geographic coordinates have not. Standard deviations of measurement error of $2.5 \mathrm{ft}$ were originally assigned to hydraulic-head measurements for these installations; these standard deviations are smaller than those for other wells in the northern part of the basin. The fit of the model to the data in this part of the basin generally is poor because of large uncertainty in the character of the subsurface, and when measurements from ZP and SAP had larger weights, they had too great an influence on parameter estimates. Thus, their standard deviations of measurement error were increased to $7.5 \mathrm{ft}$ to be comparable with those for most other head observations in the northern part of the basin.

The standard deviation of measurement error for 10 hydraulic-head observations in the vicinity of Cat Mesa Fault (figs. 3, 10B, and 10C) was increased to 20 $\mathrm{ft}$. The observed head difference across this fault is about $130 \mathrm{ft}$, whereas the maximum simulated head difference that could be achieved by reducing the horizontal hydraulic conductivity of the fault is about 
$60 \mathrm{ft}$. There is likely model error associated with the representation of this flow barrier, and by specifying a large standard deviation of measurement error (a small weight) some model error is included in the weighting. If a larger weight is assigned, the weighted residuals at these observation locations will be large and are likely to strongly affect how some parameter values change in the regression to minimize $S$ (eq. 2). If misrepresentation of Cat Mesa Fault is the fundamental problem contributing to a poor model fit at the head observation locations in the vicinity of the fault, it is not appropriate for other parameter values, such as hydraulic conductivities of large hydrogeologic units, to be strongly influenced by this poor model fit. Assigning smaller weights to these data partially resolves this problem.

There are many sources of uncertainty associated with the flow observation used in the regression procedure. The error associated with the measurement of surface-water flow at the Paseo del Norte and Rio Bravo Bridges is estimated to be \pm $14,500 \mathrm{acre}-\mathrm{ft} / \mathrm{yr}$ at each gaging station, resulting in a total measurement error associated with the loss over the reach of $\pm 29,000$ acre- $\mathrm{ft} / \mathrm{yr}$ (J. Veenhuis, Hydrologist, U.S. Geological Survey, oral commun., 1997). The variation in total surface-water flow in the Rio Grande at a single streamflow-gaging station also contributes to error in the calculated loss to the groundwater system. Finally, the value used as the flow observation in the regression is the median of a set of measured flows that span a large range. These combined sources of uncertainty warrant specifying a small weight, or large standard deviation of measurement error, on the flow observation. Initial regression runs indicated that when the standard deviation of measurement error was greater than about 4,350 acre- $\mathrm{ft} / \mathrm{yr}$ ( 15 percent of the observed flow), the flow observation had little influence on the estimated parameter values because the weighted flow residual was very small compared to many of the weighted hydraulic-head residuals. The many sources of uncertainty associated with the flow observation combine to result in an estimated standard deviation of measurement error that is clearly larger than 4,350 acre- $\mathrm{ft} / \mathrm{yr}$. The standard deviation of measurement error associated solely with the measurement of surfacewater flow at each gaging station is about 14,500 acre$\mathrm{ft} / \mathrm{yr}$; uncertainty associated with variation in daily river discharge and with the wide range of measured surface-water losses further increases this standard deviation. Consequently, a standard deviation of measurement error of 29,000 acre-ft/yr was specified, although the exact value of this standard deviation has little effect on the regression results as long as it is greater than about 4,350 acre-ft/yr.

\section{Sensitivities}

CSS values (eq. 3) are calculated for each model parameter to determine the set of parameters to estimate by nonlinear regression. The CSS values calculated for the model with subsurface configuration 1 and the initial parameter values are shown in figure 13. The CSS values calculated for the other subsurface configurations with the initial model parameter values are very similar to those shown in figure 13 , and their relative magnitudes among the parameters are also similar. The CSS values for the model with configuration 1 show that, overall, the hydraulic-head and flow data are most sensitive to the hydraulicconductivity parameters $\mathrm{K}_{\mathrm{RA}}, \mathrm{K}_{\mathrm{USF} 1}, \mathrm{~K}_{\mathrm{USF} 2}, \mathrm{~K}_{\mathrm{MSF}}$, $\mathrm{K}_{\mathrm{LSF}}$, and $\mathrm{K}_{\mathrm{LSF}-\mathrm{Z}}$; to the recharge-multiplier parameters $\mathrm{RM}_{\mathrm{Jemez}}, \mathrm{RM}_{\mathrm{S} \& \mathrm{~T}}, \mathrm{RM}_{\mathrm{M} \& \mathrm{M}}, \mathrm{RM}_{\text {Puerco, }}$ $\mathrm{RM}_{\mathrm{SE}}$, and $\mathrm{RM}_{\text {West }}$; and to the vertical anisotropy and specific yield of the basin sediments. $\mathrm{K}_{\mathrm{LSF}}$ is included in this set because although its CSS value is only slightly larger than that of three parameters not included in the set (fig. 13), the LSF zone is one of the major hydraulic-conductivity zones in the model (fig. 9), and it was deemed important to attempt estimation of this model parameter value. The data exhibit low to moderate sensitivity to the remaining parameters in configuration 1 . Subsurface configurations 3 and 4 contain one additional model parameter, $\mathrm{K}_{\mathrm{WB}}$. The CSS values of this parameter in configurations 3 and 4 are 4.9 and 4.1, respectively. The CSS values for $\mathrm{K}_{\mathrm{WB}}$ are large partly because the parameter value $b$ appears in equation 3 , and the initial value of $\mathrm{K}_{\mathrm{WB}}$ is $200 \mathrm{ft} /$ day.

On the basis of these composite scaled sensitivities, 14 or 15 model parameters were initially chosen for inclusion in the set of estimated parameters in the nonlinear-regression procedure (fig. 13). The initial set for subsurface configurations 3 and 4 includes the 14 parameters shown in figure 13 as well as $\mathrm{K}_{\mathrm{WB}}$. The set of estimated parameters for each of the configurations was reduced by three because of problems with estimating some parameters in the initial regression runs. 


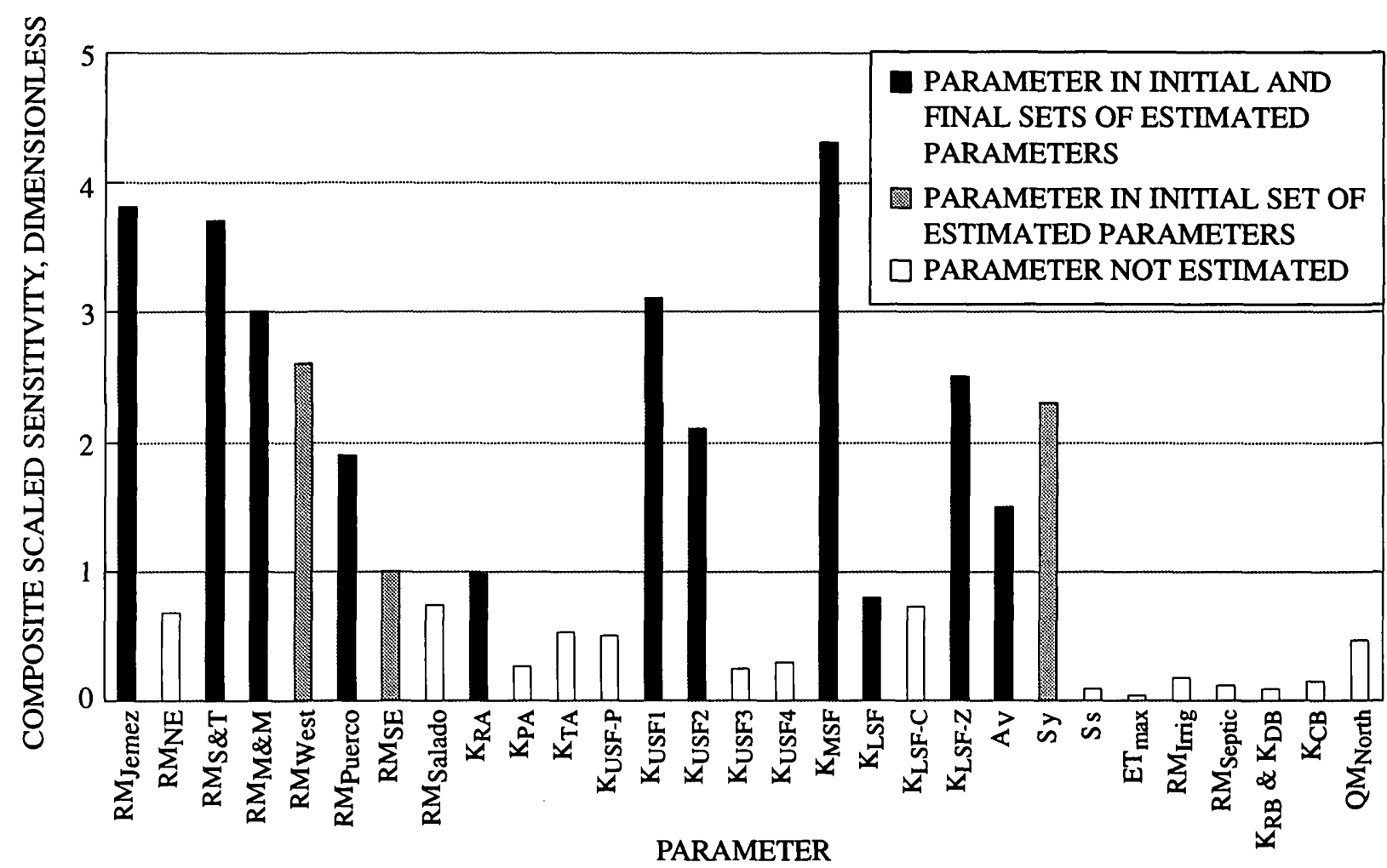

Figure 13. Composite scaled sensitivities calculated using the initial parameter values for the model with subsurface configuration 1. The composite scaled sensitivities for $K_{R B}$ and $K_{D B}$ are combined into one measure because of limitations of MODFLOWP. See text for description of parameters.

In these initial runs, the estimate of Sy tended toward a physically unreasonable value. The unreasonableness of the specific yield estimate may be related to the use of a model in the regression procedure that allows dewatering only in the uppermost model layer because of the inability of the version of MODFLOWP used in this study to perform regression for transient models with convertible layers. A related problem with estimating Sy is that the simulated equivalents of the hydraulic-head observations that are likely to be most sensitive to Sy are those in the area of greatest dewatering, but most data from these areas were removed from the calibration data set because of the large differences at these locations between simulated head in a model with layers 2 and 3 represented as convertible and simulated head in a model with layers 2 and 3 represented as confined. Because of the problems with unreasonable estimates and the absence of the most sensitive data from the calibration data set, Sy was removed from the set of estimated parameters and set to 0.2 .
In the initial regression runs for the model with each of the subsurface configurations, the regression consistently estimated negative values of $R M_{\text {West }}$ and $\mathrm{RM}_{\mathrm{SE}}$. With the initial model parameters, simulated hydraulic head at piezometers WM1A and WM2 is much higher than observed hydraulic head, and reducing or eliminating recharge along the central part of the western model boundary tends to lower simulated heads at those locations. However, there is likely some recharge across the Sand Hill Fault into the flow model. West of the western model boundary, the altitude of the Rio Puerco bed is higher than the water table in piezometers WM1 A and WM2, resulting in a hydraulic gradient from the Rio Puerco toward the Albuquerque Basin. This information was used as a rationale to retain some recharge along the western model boundary. Thus, parameter $\mathrm{RM}_{\text {West }}$ was removed from the set of estimated parameters and its value was specified to be 0.5 . The estimate of $R M_{S E}$ became negative because with the initial model parameters simulated heads in the southern part of the 
basin are generally higher than observed heads and eliminating recharge in the southeast part of the model significantly improved the fit of simulated and observed heads. Because there is likely recharge from Abo Arroyo to the ground-water system, $\mathrm{RM}_{\mathrm{SE}}$ was also removed from the set of estimated parameters and its value was fixed at 0.5 .

\section{Reasonable Parameter Ranges}

The nonlinear-regression procedure in MODFLOWP does not allow for upper and lower bounds on parameter estimates to be specified; thus, it is possible for the optimal parameter estimates to lie outside the ranges of values that are expected on the basis of prior information about the parameters. If this occurs for parameters with large CSS values, it generally indicates that there is error in the conceptual representation of the flow system that is implemented in the model or that there are problems with the calibration data or their weights (Poeter and Hill, 1997). Thus a check for reasonableness of the optimal parameter estimates is an important step in the analysis of regression results.

The reasonable ranges of values for the parameters included in the set to be estimated by the regression procedure are shown in table 5 . These ranges are generally constructed on the basis of existing information about the parameters and as noted above, play no role in the regression procedure. Plausible ranges of values for each of the rechargemultiplier parameters are not constructed because there is large uncertainty in recharge estimates from field data and from the water-budget method. The reasonable ranges of values for the hydraulicconductivity parameters are chosen on the basis of aquifer-test analyses and judgments of the likely hydraulic conductivity of the different hydrogeologic units. These judgments are made on the basis of knowledge of the depositional processes that occurred within the Albuquerque Basin and qualitative analyses of deposits collected from boreholes (for example, Hawley and Haase, 1992; Hawley and others, 1995). A reasonable range of values for $\mathrm{K}_{\mathrm{WB}}$ in subsurface configurations 3 and 4 is not constructed because there is no information about the hydraulic conductivity of possible highly permeable material in the western part of the basin. The range of expected values for $A_{V}$ is chosen on the basis of vertical anisotropy values used in other three-dimensional models of ground-water flow in basin-fill aquifers in the Southwest (Kernodle, 1992).

Table 5. Reasonable ranges of parameter values

[Hydraulic conductivity in feet per day; $A_{V}$ dimensionless]

\begin{tabular}{lc}
\hline Parameter & $\begin{array}{c}\text { Reasonable } \\
\text { range of values }\end{array}$ \\
\hline $\mathrm{K}_{\mathrm{RA}}$ & $20-150$ \\
$\mathrm{~K}_{\mathrm{USF} 2}$ & $15-60$ \\
$\mathrm{~K}_{\mathrm{USF} 1}$ & $5-30$ \\
$\mathrm{~K}_{\mathrm{MSF}}$ & $2-10$ \\
$\mathrm{~K}_{\mathrm{LSF}-\mathrm{Z}}$ & $4-20$ \\
$\mathrm{~K}_{\mathrm{LSF}}$ & $0.5-5$ \\
$\mathrm{~A}_{\mathrm{V}}$ & $100-5,000$ \\
\hline
\end{tabular}

In addition to being within their respective reasonable ranges of values, the hydraulic-conductivity estimates for the Santa Fe Group deposits should have the proper relative hydraulic conductivities. Information about the basin depositional processes suggests that the relative hydraulic conductivities of these deposits, from lowest to highest hydraulic conductivity, should be: $\mathrm{K}_{\mathrm{LSF}}, \mathrm{K}_{\mathrm{MSF}}, \mathrm{K}_{\mathrm{USF} 1}, \mathrm{~K}_{\mathrm{USF} 2}$. The value of $\mathrm{K}_{\mathrm{LSF}-\mathrm{Z}}$ should be greater than that of $\mathrm{K}_{\mathrm{LSF}}$ because the Zia Sand is an eolian sand that is likely more permeable than the fine-grained deposits of the undivided lower part of the Santa Fe Group.

\section{MODEL EVALUATION}

The nonlinear least-squares regression method was applied to the ground-water flow model of the Albuquerque Basin with each of subsurface configurations $1,2,3,4,5$, and 6 . The resulting six calibrations of the model are referred to as calibrations $1,2,3,4,5$, and 6. Model linearity, normality of the weighted residuals, optimal parameter estimates and parameter confidence intervals, and parameter correlations are assessed for all six model calibrations. Model fit and model error are then evaluated for a subset of the calibrations. 


\section{Model Linearity and Normality of Weighted Residuals}

The approximate, individual, linear 95-percent confidence intervals for the parameters are accurate if (1) the model is correct, (2) the model is effectively linear with respect to the parameters, and (3) the weighted residuals are normally distributed. The validity of the second and third conditions is therefore examined prior to the presentation of the optimal parameter estimates and confidence intervals.

The modified Beale's measure assesses the linearity of a model in the vicinity of the optimal parameter estimates by comparing simulated hydraulic heads and flows at the observation locations with linearized estimates of these quantities (Cooley and Naff, 1990, p. 187-189). The simulated and linearized quantities were calculated using sets of parameter values that are at the bounds of the confidence regions on the parameters. The modified Beale's measure was computed for each of the six calibrations of the Albuquerque Basin flow model (table 6) using the program BEALEP (Hill, 1994, p. 45-54). On the basis of criteria suggested by Cooley and Naff (1990), the model with each of the subsurface configurations is roughly linear if the modified Beale's measure is less than 0.05 and is highly nonlinear if the measure is greater than 0.55 . As shown by the statistics in table 6 , the model with subsurface configurations 3 and 4 is highly nonlinear, whereas the model with subsurface configurations $1,2,5$, and 6 is moderately nonlinear. Thus, the assumption of model linearity needed for the linear confidence intervals to be accurate is not met for the model with any of the subsurface configurations, and addition of the west basin high-K zone to the model significantly increases its nonlinearity.

The independence and normality of the weighted residuals can be assessed through use of the (1) correlation coefficient $\mathrm{R}^{2}{ }_{\mathrm{N}}$ between the ordered weighted residuals and order statistics from the normal probability distribution function (Hill, 1992, p. 63) and (2) normal probability plots of the weighted residuals. If the computed value of $R^{2}$ for a calibration is below the critical value, the hypothesis is rejected that the weighted residuals are independent and normally distributed. The critical value of $R^{2}{ }_{N}$ is 0.987 for a set of 200 observations; this is the maximum number of observations for which such a value has been tabulated. The critical value for 803 observations will be larger than 0.987 because the critical value increases with the number of data. The value of $R^{2}$ for all calibrations (table 6) is somewhat smaller than 0.987 , indicating that the residuals are not strictly independent and normally distributed. Normal probability plots of the weighted residuals (fig. 14) show graphically a reason that there is a slightly greater departure from normality for calibrations 3 and 4 compared with the other calibrations. On these graphs, the weighted residuals will plot on a straight line if they are independent and normally distributed. At the tails of the normal probability plots for calibrations 3 and 4 there is greater departure from a straight line than at the tails of the plots for the other calibrations.

Because for each of the calibrations the value of $\mathrm{R}^{2} \mathrm{~N}$ is less than the critical value and the normal probability plots do not form a straight line, the weighted residuals evidently are not independent and normally distributed. The residuals could be correlated and normally distributed, however, and Cooley and Naff (1990, p. 168-170) presented a method of generating correlated normal random deviates to test this possibility. If the shape of the normal probability plots of the weighted residuals and of these deviates are similar, then the nonlinearity of the plots in figure 14 might be explained by correlation among the weighted residuals. In the normal probability plots of correlated

Table 6. Modified Beale's measure and $\mathrm{R}^{2} \mathrm{~N}$

[All statistics dimensionless]

\begin{tabular}{lcccccc}
\hline & \multicolumn{7}{c}{ Calibration } \\
\cline { 2 - 7 } Statistic & $\mathbf{1}$ & $\mathbf{2}$ & $\mathbf{3}$ & $\mathbf{4}$ & $\mathbf{5}$ & $\mathbf{6}$ \\
\hline Modified Beale's measure & 0.27 & 0.22 & 1.4 & 2.5 & 0.20 & 0.21 \\
$\mathrm{R}^{2} \mathrm{~N}$ & 0.976 & 0.975 & 0.945 & 0.947 & 0.975 & 0.974 \\
\hline
\end{tabular}




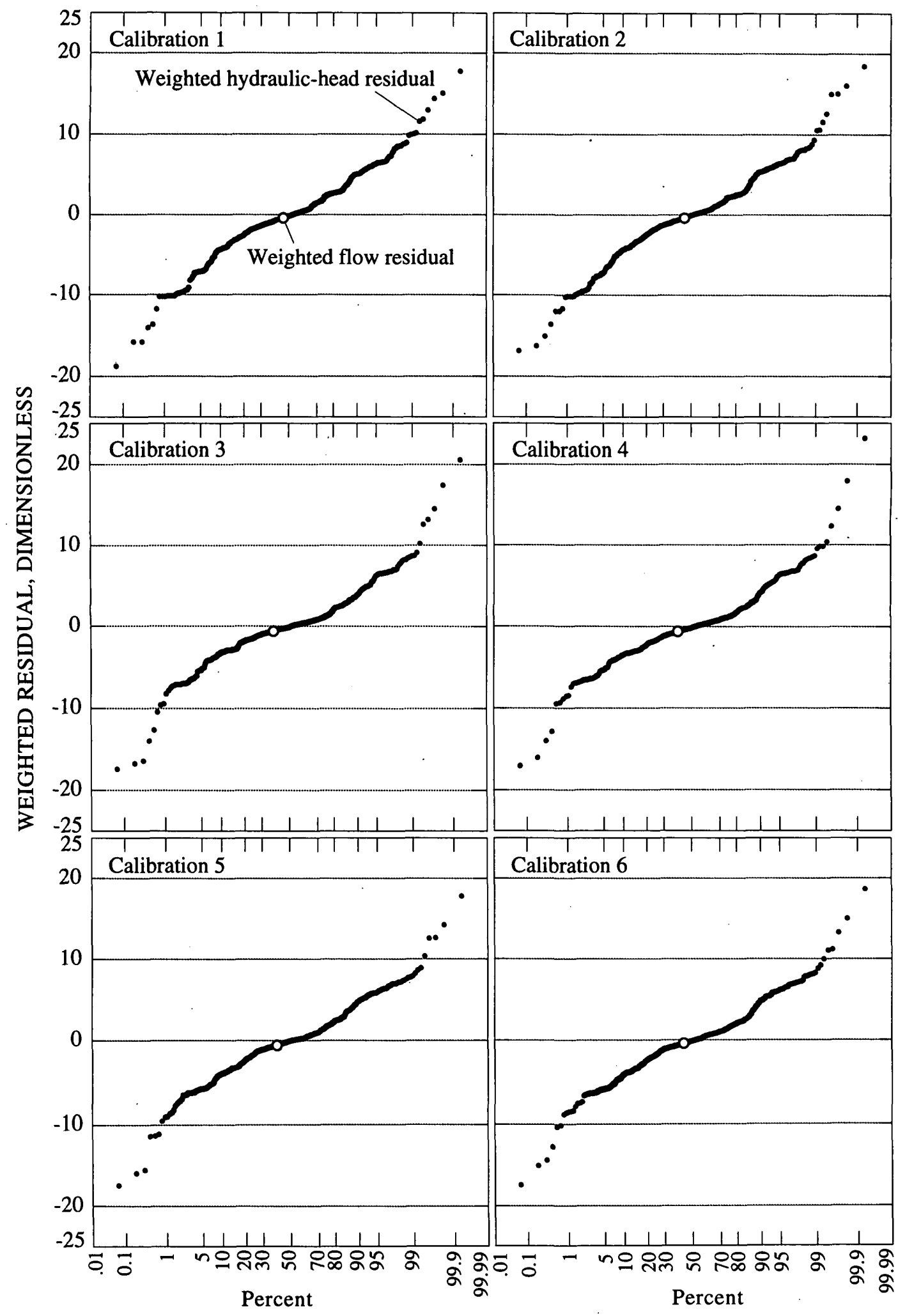

Figure 14. Normal probability plots of weighted residuals. 
normal random deviates for each of the six calibrations, however, the deviates lie nearly on a straight line. Consequently, the shapes of the normal probability plots for the weighted residuals clearly cannot be explained by correlation among the weighted residuals, and it must be concluded that the weighted residuals are not strictly normally distributed.

\section{Optimal Parameter Estimates}

The optimal parameter estimates in each model calibration are shown in table 7. In calibrations 1, 2, 4, and 6, $\mathrm{RM}_{\text {Puerco }}$ is specified rather than estimated because the value of this parameter became negative during the regression for these calibrations. This parameter became negative because initial simulated hydraulic heads in the southern part of the basin are mostly higher than observed heads, and eliminating recharge along the Rio Puerco generally improves model fit. Recharge from the Rio Puerco to the ground- water system is likely, however, and thus the value of $\mathrm{RM}_{\text {Puerco }}$ was set to 0.3 in calibrations $1,2,4$, and 6 because this value is within the range of the estimates of $\mathrm{RM}_{\text {Puerco }}$ in calibrations 3 and 5 (table 7). The optimal estimates of the hydraulic-conductivity and anisotropy parameters and the approximate, individual, linear 95-percent confidence intervals for these parameters are plotted in figure 15 with respect to the reasonable ranges of values. The limits of each confidence interval are approximated as the optimal parameter estimate plus and minus two times the parameter standard deviation, which is calculated as part of the nonlinear-regression procedure (see Hill, 1992, p. 57-58). Because (1) there is likely model error on account of the large uncertainty about conditions in many parts of the basin, (2) the modified Beale's measure indicates that the model with each of the subsurface configurations is moderately to highly nonlinear, and (3) in each of the calibrations the weighted residuals are not strictly normally distributed, these confidence intervals may be inaccurate and

Table 7. Optimal parameter estimates

[Recharge multiplier and vertical anisotropy dimensionless; hydraulic conductivity in feet per day; --, parameter not estimated]

\begin{tabular}{lcccccc}
\hline & \multicolumn{5}{c}{ Optimal estimate in calibration } \\
\cline { 2 - 7 } Parameter & 1 & 2 & 3 & 4 & 5 & 6 \\
\hline RM $_{\text {Jemez }}$ & 0.90 & 0.92 & 0.92 & 1.7 & 0.47 & 0.74 \\
$\mathrm{RM}_{\mathrm{S} \& \mathrm{~T}}$ & 0.88 & 0.83 & 0.56 & 0.54 & 0.67 & 0.64 \\
$\mathrm{RM}_{\mathrm{M} \& \mathrm{M}}$ & 0.57 & 0.42 & 0.47 & 0.45 & 0.57 & 0.31 \\
$\mathrm{RM}_{\text {Puerco }}$ & 0.3 & 0.3 & 0.35 & 0.3 & 0.14 & 0.3 \\
& (fixed) & (fixed) & & (fixed) & & (fixed) \\
$\mathrm{K}_{\mathrm{RA}}$ & 209 & 175 & 101 & 73 & 173 & 150 \\
$\mathrm{~K}_{\mathrm{USF} 2}$ & 50 & 43 & 34 & 32 & 42 & 34 \\
$\mathrm{~K}_{\mathrm{USF} 1}$ & 129 & 97 & 39 & 40 & 66 & 39 \\
$\mathrm{~K}_{\mathrm{MSF}}$ & 11 & 10 & 4.1 & 3.4 & 3.9 & 8.4 \\
$\mathrm{~K}_{\mathrm{LSF}-\mathrm{Z}}$ & 3.8 & 2.6 & 4.7 & 5.5 & 2.4 & 2.0 \\
$\mathrm{~K}_{\mathrm{LSF}}$ & 2.4 & 2.6 & 2.0 & 0.94 & 3.9 & 2.9 \\
$\mathrm{~K}_{\mathrm{WB}}{ }^{1}$ & - & -- & 141 & 127 & -- &.- \\
$\mathrm{A}_{\mathrm{V}}$ & 3,500 & 2,600 & 450 & 330 & 1,660 & 1,200 \\
\hline \multicolumn{1}{c}{${ }^{\prime} \mathrm{K}_{\mathrm{WB}}$ is a model parameter only in calibrations 3 and 4. } & & & \\
\hline
\end{tabular}



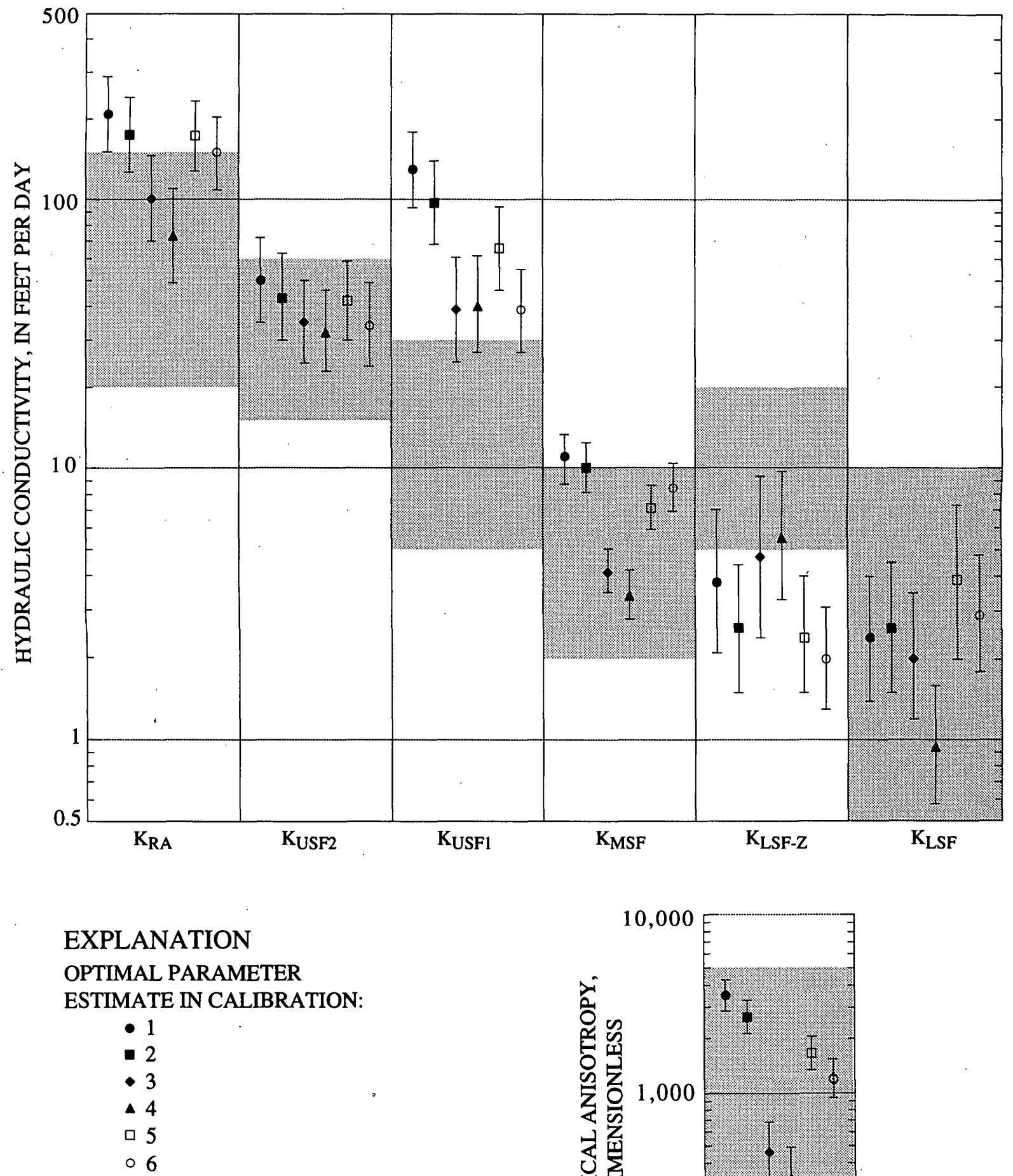

T APPROXIMATE, LINEAR 95-PERCENT 1 CONFIDENCE INTERVAL

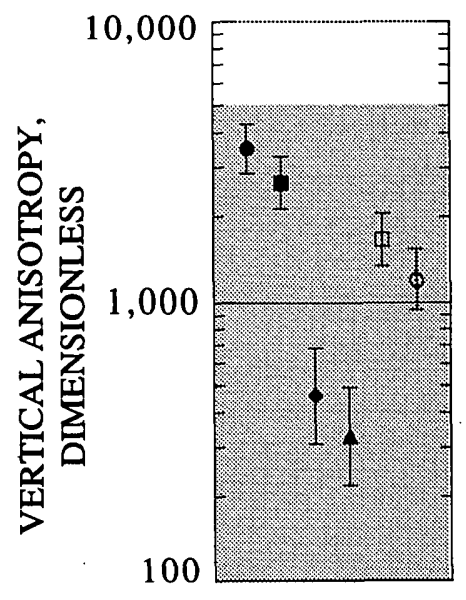

$A_{V}$

Figure 15. Optimal parameter estimates and approximate, linear 95-percent confidence intervals. Shaded regions are the reasonable range of values for each parameter. 
should be considered rough indicators of parameter uncertainty. There is greater uncertainty about the accuracy of the confidence intervals for calibrations 3 and 4 than for the other calibrations because the model with subsurface configurations 3 and 4 is highly nonlinear and because the distributions of weighted residuals for calibrations 3 and 4 exhibit greater departure from normality than do the distributions for the other calibrations.

In calibration 1, for the model with the simplest of the six subsurface configurations, the optimal estimates of $\mathrm{K}_{\mathrm{USF} 2}$ and $\mathrm{K}_{\mathrm{LSF}}$ are within the expected ranges of values, but the estimates of the remaining hydraulic-conductivity parameters lie outside these expected ranges. The optimal estimates of $\mathrm{K}_{\mathrm{RA}}$ and $\mathrm{K}_{\mathrm{USF} 1}$ are well outside the reasonable ranges of values, and the confidence intervals on these parameters are entirely outside these ranges. Despite the possible inaccuracies in the linear confidence intervals shown in figure 15 , the nonlinear confidence interval on $\mathrm{K}_{\mathrm{USF} 1}$ is unlikely to be so different from the linear confidence interval that it extends into the expected range of values for this parameter. In addition, the estimate of $\mathrm{K}_{\mathrm{USF} 1}$ is much higher than that of $\mathrm{K}_{\mathrm{USF} 2}$, violating the condition that the hydraulic conductivities for the Santa Fe Group deposits have the correct relative magnitudes. The estimate of $\mathrm{K}_{\mathrm{MSF}}$ is somewhat larger than is reasonable and the estimate of $\mathrm{K}_{\mathrm{LSF}-\mathrm{Z}}$ is somewhat smaller than is reasonable, although the linear confidence intervals on these parameters lie partially within the expected ranges. It is likely that the representation of the subsurface in the northwestern part of the flow model is an oversimplification and that additional deposits besides the Zia Sand are present. The overly small estimate of $\mathrm{K}_{\mathrm{LSF}-\mathrm{Z}}$ may be compensating for this model error. The estimate of $A_{V}$ in calibration 1 is fairly large but is within the expected range of values. The optimal estimates of $\mathrm{RM}_{\mathrm{Jemez}}, \mathrm{RM}_{\mathrm{S} \& \mathrm{~T}}$, and $\mathrm{RM}_{\mathrm{M} \& \mathrm{M}}$ are all less than 1.0 (table 7), indicating that the estimated recharge along the Jemez River and along the central part of the eastern basin boundary is less than that calculated by the water-budget method.

The parameter estimates in calibration 2 are not significantly different from those in calibration 1 (table 7; fig. 15). Increasing the thickness of the basin deposits by a factor of about three results in optimal estimates of most of the hydraulic-conductivity parameters that are somewhat smaller than the estimates in calibration 1, which is expected. However, the estimate of $\mathrm{K}_{\mathrm{USF} 1}$ and its linear confidence interval remain well outside the expected range of parameter values, and the estimate of $\mathrm{K}_{\mathrm{RA}}$ is still larger than is expected. The recharge-multiplier estimates are such that there is slightly less simulated recharge along the eastern mountains than in calibration 1 and about the same simulated recharge along the Jemez River.

In calibration 3, for the model with the subsurface configuration in which basin deposits are $1,600 \mathrm{ft}$ thick beneath the Rio Grande and the west basin high- $\mathrm{K}$ zone is included, the optimal estimates of and linear confidence intervals on $\mathrm{K}_{\mathrm{RA}}, \mathrm{K}_{\mathrm{USF} 2}, \mathrm{~K}_{\mathrm{MSF}}$, and $\mathrm{K}_{\mathrm{LSF}}$ lie entirely within the reasonable ranges of parameter values. The estimate of $\mathrm{K}_{\mathrm{USF} 1}$ remains outside the reasonable range of values and is slightly larger than that of $\mathrm{K}_{\mathrm{USF} 2}$, but $\mathrm{K}_{\mathrm{USF} 1}$ is much closer to the expected range than in calibrations 1 and 2 . Addition of the west basin high-K zone results in significantly smaller estimates of $\mathrm{K}_{\mathrm{USF} 1}, \mathrm{~K}_{\mathrm{RA}}$, and $\mathrm{K}_{\mathrm{MSF}}$ than in calibrations 1 and 2 partly because the presence of the west basin high-K zone results in substantially lower simulated hydraulic head in the western part of the basin; thus $\mathrm{K}_{\mathrm{USF} 1}, \mathrm{~K}_{\mathrm{RA}}$, and $\mathrm{K}_{\mathrm{MSF}}$ do not become as unreasonably large to achieve this effect. The estimate of $\mathrm{K}_{\mathrm{USF} 1}$ remains outside the reasonable range in calibration 3 partly because the larger estimate of this parameter tends to result in a better fit of simulated and observed heads at many locations in the southern part of the basin than does a smaller value of $\mathrm{K}_{\mathrm{USF} 1}$. Application of the nonlinearregression method to the model with a modified subsurface configuration 3 that in the southeast part of the basin contains a larger USF 2 hydraulicconductivity zone and a smaller USF1 hydraulicconductivity zone than those shown in figure 9 did not significantly improve the reasonableness of the $\mathrm{K}_{\mathrm{USF} 1}$ estimate. The estimate of $\mathrm{K}_{\mathrm{WB}}$ in calibration 3 indicates that in the model with subsurface configuration 3 , a hydraulic conductivity of the west basin high-K zone of about $140 \mathrm{ft} /$ day lowers hydraulic heads in the area of the ground-water trough such that a reasonable match of simulated and observed heads is attained. In calibration 3, the estimate of $A_{V}$ is significantly smaller than that in calibrations 1 and 2 . The recharge-multiplier estimates in calibration 3 are such that simulated recharge along the Jemez River is about equal to that calculated by the water-budget method; simulated recharge along the Sandia, Manzano, and Manzanita Mountains and Tijeras Arroyo is about one-half that calculated by the waterbudget method; and simulated recharge along Rio 
Puerco is about one-third that calculated by the waterbudget method.

In calibration 4 , for the subsurface configuration containing thicker basin deposits as well as the west basin high-K zone, most optimal hydraulicconductivity estimates, including that of the west basin high-K zone, are somewhat smaller than those in calibration 3 (table 7; fig. 15). The estimate of $\mathrm{K}_{\mathrm{USF} 1}$ is about the same as that in calibration 3 and the estimate of $\mathrm{K}_{\mathrm{LSF}-\mathrm{Z}}$ is slightly larger. Compared to calibration 3, the optimal estimate of $\mathrm{RM}_{\mathrm{Jemez}}$ in calibration 4 is 1.8 times larger, whereas the estimates of $\mathrm{RM}_{S \& \mathrm{~T}}$ and of $\mathrm{RM}_{\mathrm{M} \& \mathrm{M}}$ are fairly similar. The larger estimate of $\mathrm{RM}_{\mathrm{Jemez}}$ results because addition of the deeper layers in the model with subsurface configuration 4 results in a substantial decrease in simulated hydraulic heads in the northwestern part of the basin compared to simulated heads in the model with configuration 3 , all else being equal. In calibration 4 , the estimate of $\mathrm{K}_{\mathrm{LSF}-\mathrm{Z}}$ is only slightly larger than that in calibration 3; thus the estimate of $\mathrm{RM}_{\mathrm{Jemez}}$ is substantially larger so that in the northwestern part of the basin the simulated heads are similar to those in calibration 3 .

As did the addition of the west basin high-K zone in calibrations 3 and 4 , addition of the low-K fault zone to the model in calibrations 5 and 6 results in some hydraulic-conductivity estimates that are more reasonable than those in calibrations 1 and 2 (table 7; fig. 15). In calibration 5, for the model with the subsurface configuration containing the low-K fault zone and 1,600-ft-thick basin deposits beneath the Rio Grande, the estimates of $\mathrm{K}_{\mathrm{LSF}}, \mathrm{K}_{\mathrm{MSF}}$, and $\mathrm{K}_{\mathrm{USF} 2}$ are within the expected ranges. The estimate of $K_{\mathrm{RA}}$ lies outside the reasonable range of values and the estimate of and linear confidence interval for $\mathrm{K}_{\mathrm{USF} 1}$ lie well outside the expected range of values. In calibration 6 , however, the optimal estimate of $\mathrm{K}_{\mathrm{USF} 1}$ is much closer to the reasonable range than that in calibrations 1,2 , and 5. The optimal estimate of $\mathrm{K}_{\mathrm{RA}}$ lies at the upper end of the expected range. Thus, the lowering of simulated hydraulic heads in the western part of the basin that is caused by the addition of the low- $K$ fault zone in the model with 5,000-ft-thick basin deposits helps prevent the estimate of $\mathrm{K}_{\mathrm{USF} 1}$ from becoming as unreasonably large as those in calibrations 1 and 2 . The estimates of $\mathrm{K}_{\mathrm{LSF}-\mathrm{Z}}$ are smaller in calibrations 5 and 6 than in the other four calibrations and their linear confidence intervals lie entirely outside the reasonable range. In addition, the estimates of $\mathrm{K}_{\mathrm{LSF}-\mathrm{Z}}$ are smaller than the estimates of $\mathrm{K}_{\mathrm{LSF}}$, which is contrary to prior information about the relative hydraulic conductivities of these lower Santa Fe Group deposits. As discussed above, the overly small estimate of $\mathrm{K}_{\mathrm{LSF}-\mathrm{Z}}$ may be due in part to oversimplification of the hydraulicconductivity zonation in the northwestern part of the model domain. The estimates of $A_{V}$ in calibrations 5 and 6 are smaller than those of calibrations 1 and 2 and larger than those of calibrations 3 and 4 . The rechargemultiplier estimates in calibrations 5 and 6 are all less than 1.0, indicating that the estimated recharge in these calibrations is less than that calculated by the waterbudget method.

Comparison of the optimal parameter estimates for the six calibrations suggests that given the boundary conditions, zonation of hydrogeologic units, and specified parameter values in the flow model and the calibration data set used in the regression, calibrations 3 and 4 as a whole have the most reasonable parameter estimates. Overall, the optimal parameter estimates in calibration 6 are somewhat less reasonable than the estimates in calibrations 3 and 4, but are generally closer to the expected parameter ranges than the estimates in calibrations 1 and 2 . In calibrations 3, 4, and 6, the estimate of $\mathrm{K}_{\mathrm{USF} 1}$ remains larger than is expected given prior information about the realistic range of values for this hydraulicconductivity parameter, but the estimate is much closer to this expected range than in the other calibrations. The results for calibrations 3,4 , and 6 suggest that addition of a model feature that lowers simulated hydraulic heads in the vicinity of the ground-water trough observed in the western part of the basin can significantly improve the reasonableness of some hydraulic-conductivity estimates. The result that some optimal parameter estimates remain outside the expected ranges even when the model contains features that substantially lower simulated hydraulic heads in the western part of the basin indicates that the model is not yet completely satisfactory and strongly suggests that additional changes need to be made to the conceptual model of the basin hydrology and geology that is implemented in the numerical flow model.

In the work presented here, several major modifications were made to the representation of subsurface conditions in the model of Kernodle (1998). These include changes made in all subsurface configurations, such as the reduction of the horizontal hydraulic conductivity of the Cat Mesa and West Sandia Faults and the extension of the USF2 hydraulicconductivity zone to the north, as well as changes that 
are implemented only in a subset of the subsurface configurations. Generally, these modifications were prompted by the need to reproduce a major feature in the observed hydraulic heads or by geologic interpretations of basin deposits or basin structure. Additional revisions aimed at constructing a representation of the basin subsurface that when implemented in the regression model results in a reasonable optimal estimate of $\mathrm{K}_{\mathrm{USF} 1}$ were not pursued. The reasons for this included: (1) there were no obvious additional changes to the conceptual model of the basin subsurface that would better reproduce major features of the observed hydraulic heads and (2) significant revision of the conceptual model of the basin subsurface is planned, on the basis of the ongoing hydrologic, geologic, and geophysical investigations that are part of the U.S. Geological Survey Middle Rio Grande Basin study (Bartolino, 1997; Slate, 1998). This revised conceptual model is planned to be incorporated into a future version of the numerical flow model.

Furthermore, it is highly likely that there are other modifications to the basin structure, configuration of hydrogeologic units, and boundary conditions that will produce lower simulated hydraulic heads in the vicinity of the ground-water trough in the western part of the basin, and that will result in more reasonable optimal parameter estimates than those in the calibrations presented here. For example, in a model with different boundary conditions and different hydraulic-conductivity zonation of the primary Santa Fe Group deposits, observed hydraulic heads in the western part of the basin might be reproduced by adding much more isolated zones of highly permeable deposits than is done in subsurface configurations 3 and 4 presented here. The low-K fault zone included in subsurface configurations 5 and 6 is designed to test the concept that a tightly cemented fault might play a role in the formation of the ground-water trough. There are many additional possible locations for tightly cemented faults than the location of the low-K fault zone shown in figure 9 that are likely to result in lower simulated hydraulic heads in the western part of the basin. Alternatively, a basin representation with some combination of tightly cemented faults and isolated volumes of deposits that are more permeable than adjacent deposits might play a role in the creation of the ground-water trough. In addition, horizontal anisotropy might contribute to preferential flow along the axis of the trough.

Parameter correlations for each calibration were computed using the approximate covariance matrix for the parameters, which is calculated as part of the nonlinear-regression method (Hill, 1992, p. 57-61). If a pair of parameters has a correlation near 1.0 or -1.0 , this suggests that given the calibration data set used in the regression, independent estimation of the two parameters may not be possible. In each of the calibrations, parameters $\mathrm{RM}_{\mathrm{Jemez}}$ and $\mathrm{K}_{\mathrm{LSF}-\mathrm{Z}}$ have the largest correlation of any pair. The computed correlations between these two parameters are shown in table 8. The largest correlation is 0.97 in calibration 4. Such a large correlation can result in non-unique parameter estimates, but when the regression for the model with subsurface configuration 4 is started using different initial parameter values, the optimal parameter estimates always converge to those shown in table 7. The parameter correlations for the other five calibrations are not large enough to be problematic, as typically only correlations greater than 0.95 result in problems with parameter non-uniqueness (Hill, 1998).

The composite scaled sensitivities calculated using the initial parameter values (fig. 13) guided which model parameters to estimate in the nonlinearregression procedure and which to specify. However, the CSS values are dependent on the parameter values because the sensitivities in equation 3 are a nonlinear function of the model parameters and because $b$ appears in this equation. The CSS values calculated

Table 8. Correlation between $\mathrm{RM}_{\text {Jemez }}$ and $\mathrm{K}_{\mathrm{LSF}-\mathrm{Z}}$ in each calibration

[Correlation dimensionless]

\begin{tabular}{lccccccc}
\hline & \multicolumn{8}{c}{ Calibration } \\
\cline { 2 - 8 } & $\mathbf{1}$ & $\mathbf{2}$ & $\mathbf{3} \cdot$ & $\mathbf{4}$ & $\mathbf{5}$ & $\mathbf{6}$ \\
\hline Correlation between $\mathrm{RM}_{\mathrm{Jemez}}$ and $\mathrm{K}_{\mathrm{LSF}-\mathrm{Z}}$ & 0.86 & 0.82 & 0.93 & 0.97 & 0.76 & 0.81 \\
\hline
\end{tabular}


using the optimal parameter estimates for calibrations 2,4 , and 6 are shown in figure 16 . The relative magnitudes of the CSS values calculated for the optimal parameter estimates in calibrations 1,3 , and 5 are similar to the relative magnitudes of the CSS values for calibrations 2, 4, and 6, respectively. In each calibration the estimated parameters generally still have the largest CSS values of all the parameters. The primary exception is parameter Sy.

\section{Model Fit and Model Error}

Model fit and model error are evaluated primarily for calibrations 4 and 6 , although some measures are presented for all calibrations. Analysis of the optimal parameter estimates revealed that overall, the estimates are most reasonable in calibrations 3 and 4. The results for calibration 4 are evaluated instead of those for calibration 3 because geologic and geophysical data suggest that the representation of basin thickness is more realistic in subsurface configuration 4 than in configuration 3. Model results are also evaluated for calibration 6 because the low-K fault zone in subsurface configuration 6 results in lower simulated hydraulic heads in the vicinity of the groundwater trough in the western part of the basin, and the estimates of $\mathrm{K}_{\mathrm{RA}}, \mathrm{K}_{\mathrm{USF} 1}$, and $\mathrm{K}_{\mathrm{MSF}}$ are more reasonable in calibration 6 than in calibrations 1 and 2 , suggesting that the model with subsurface configuration 6 is an improvement over the starting model. Although some parameter estimates in calibrations 4 and 6 remain outside of their respective reasonable ranges of values, indicating that the model is not yet completely satisfactory, evaluation of model fit and model error is useful for identifying locations of problems with the model and for comparing the results of calibrations 4 and 6 . The evaluation of model fit and model error is accomplished through calculation of the standard error of the regression, graphical analyses of the weighted hydraulic-head residuals, and comparison of simulated and observed hydraulic heads and flows.

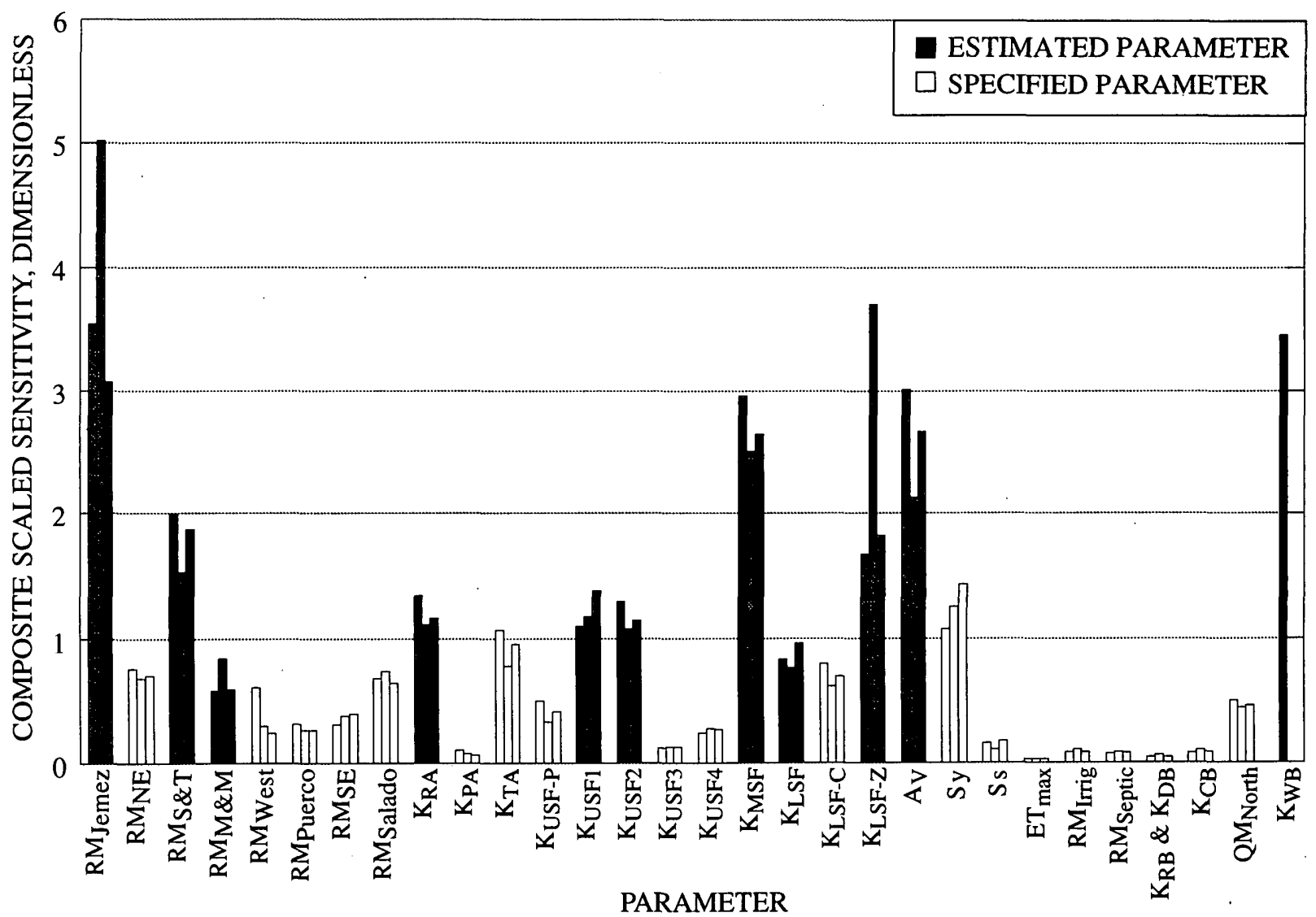

Figure 16. Composite scaled sensitivities calculated using the optimal parameter estimates in calibrations 2 (left bar), 4 (middle bar), and 6 (right bar). The composite scaled sensitivities for $\mathrm{K}_{\mathrm{RB}}$ and $\mathrm{K}_{\mathrm{DB}}$ are combined into one measure because of limitations of MODFLOWP. See text for description of parameters. 


\section{Standard Error of Regression}

The standard error of regression is a measure of overall model fit to the calibration data, and is computed as:

$$
s=\left(\frac{S}{n-p}\right)^{\frac{1}{2}},
$$

where $p$ is the number of estimated parameters. The standard errors for the six different calibrations of the Albuquerque Basin ground-water flow model range from 3.4 to 4.0 (table 9). The standard errors for calibrations $3,4,5$, and 6 are 10 to 15 percent smaller than those for calibrations 1 and 2, indicating that addition of a subsurface feature that lowers hydraulic heads in the western part of the basin results in a moderate improvement in the overall fit of simulated and observed conditions. The standard error of regression can be interpreted as follows (Hill, 1998, p. 18). If the standard error for a model is equal to 1.0 , then the model fit is consistent with the observation weights, which reflect measurement error. If the weights correctly represent the measurement errors, then standard errors larger than 1.0 indicate likely model error. That there is likely model error is not surprising because in many parts of the basin little information is available about hydrogeologic conditions. Additional potential sources of model error include inadequate representation of the spatial and temporal variation of recharge, oversimplification of hydrologic boundary conditions in the inner valley, and misrepresentation of the normal faults located throughout the basin.

To obtain a measure of effective fit that reflects both model and measurement error, the standard error can be multiplied by the standard deviation of measurement error used to calculate the observation weights (Hill, 1998, p. 19). By this approach, the overall effective fit of the Albuquerque Basin flow model with subsurface configurations 4 and 6 to the sets of head observations with standard deviations of measurement error equal to $2.5,5.0,7.5$, and $10.0 \mathrm{ft}$ is about $9,18,26$, and $35 \mathrm{ft}$, respectively. These values reflect the magnitude of the unweighted root mean square discrepancy between simulated and observed heads for the four sets of head observations.

\section{Weighted Hydraulic-Head Residuals}

Graphical analyses of the weighted residuals facilitate assessment of model bias or error and of model fit to the calibration data. These analyses include plots of the weighted residuals against weighted simulated values and of the spatial and temporal distribution of the weighted hydraulic-head residuals.

The plot of weighted residuals against weighted simulated values (fig. 17) ideally should show a random distribution of the weighted residuals above and below zero for all weighted simulated values. The plots in figure 17 for calibrations 4 and 6 mostly exhibit the desired random weighted-residual distribution. In addition, the weighted residual for the one flow observation lies near the center of the range of weighted hydraulic-head residuals. The clustering of weighted hydraulic-head residuals within five groups of weighted simulated values results because (1) the simulated hydraulic heads lie in a fairly narrow range, from about 4,700 to 5,500 ft above sea level, and (2) the weight on each hydraulic-head observation is equal to one of five discrete values, ranging from 0.05 to 0.4 . For calibrations 4 and 6 , the spread of weighted residuals about zero is significantly greater for weighted simulated values between about 600 and 750 than for other weighted simulated values. This group of weighted residuals includes most of the hydraulic-head observations in the northern part of the basin, where model fit is significantly worse than in other parts of the basin, as discussed in more detail below.

More detailed comparison of model fit to the data and assessment of model error are accomplished through analysis of the spatial and temporal distribution of weighted hydraulic-head residuals.

Table 9. Standard errors of regression

[Standard error dimensionless]

\begin{tabular}{lccccccc}
\hline & \multicolumn{7}{c}{ Calibration } \\
\cline { 2 - 7 } & $\mathbf{1}$ & $\mathbf{2}$ & $\mathbf{3}$ & $\mathbf{4}$ & $\mathbf{5}$ & $\mathbf{6}$ \\
\hline Standard error of regression & 4.0 & 4.0 & 3.4 & 3.4 & 3.6 & 3.5 \\
\hline
\end{tabular}




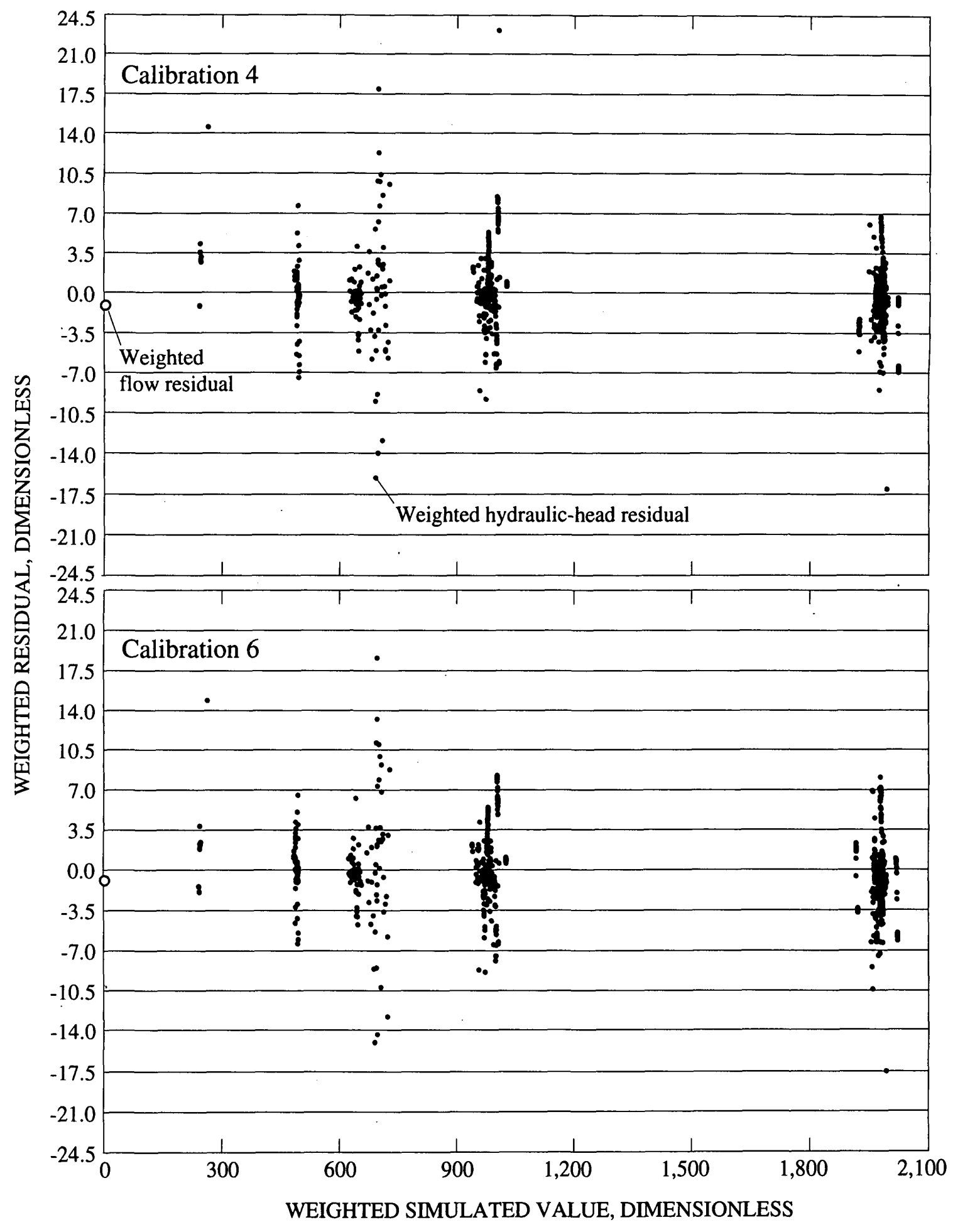

Figure 17. Weighted residuals against weighted simulated values. 
Maps of weighted residuals for calibrations 4 and 6 in the 1950's, 1992, and 1994 plotted on the model domain (fig. 18) show the model fit to the hydraulichead data relative to the expected fit. Because of measurement error, mostly associated with lack of information on measuring-point altitudes, screened interval locations, and contribution of hydraulic heads at different depths to the hydraulic-head measurements from wells with long screened intervals, simulated heads are not expected to exactly match measured heads. Ideally, negative and positive weighted residuals should be small and randomly distributed in space. Clustering of residuals with similar signs and magnitudes is indicative of model error.

In the 1950's (fig. 18A-B), all weighted hydraulic-head residuals are less than 8 , in absolute value, except for one weighted residual in the southern part of the basin. At the shallow wells in the 1950's simulations, there are no areas in which the magnitude or sign of a group of weighted residuals differs substantially for calibrations 4 and 6 . Differences occur mainly at locations where the weighted residuals are small in absolute value and the sign of the residual differs. In both calibrations, there are generally a greater number of negative weighted residuals than positive weighted residuals, but this problem is not extreme. At the deep wells in the 1950's, the distributions of weighted hydraulic-head residuals for calibrations 4 and 6 are also similar. Most weighted residuals are less than 2 in absolute value but in both calibrations there is clustering of same-sign residuals in some parts of Albuquerque and near Los Lunas. The distribution of positive and negative weighted residuals in the vicinity of Tijeras Arroyo is much more random.

In 1992 and 1994 at the shallow wells in the central and southern parts of the basin, the weighted residuals in calibrations 4 and 6 are generally small to moderate in magnitude and there are few major differences in the distributions for the two calibrations (fig. 18C-F). In both calibrations, there is some clustering of same-sign weighted residuals. In the central part of the basin, this problem is not extreme. In the southern part of the basin where data are sparse for 1992, a preponderance of negative weighted residuals for 1994, especially east of the Rio Grande, indicates that at most locations simulated hydraulic heads are higher than observed heads. As noted in the discussion of optimal parameter estimates for calibration 3, increasing $\mathrm{K}_{\mathrm{USF} 1}$ so that it lies outside the expected range of parameter values tends to improve model fit in the southern part of the basin because larger values of $\mathrm{K}_{\mathrm{USF} 1}$ result in lower simulated hydraulic heads in this area. With a smaller but more reasonable value of $\mathrm{K}_{\mathrm{USF} 1}$ in the model, the negative weighted residuals in the southern part of the basin would be larger in absolute value. This result suggests likely error in the representation of hydrogeologic units in the southern part of the basin.

In the northern part of the basin where data from shallow wells are available mostly for 1994, most weighted hydraulic-head residuals are large in absolute value (fig. 18E-F), and there is a clear pattern of positive weighted residuals at the basin margins and negative weighted residuals in the basin interior, resulting from simulated hydraulic heads that are generally too low at the margins and too high in the interior. The poor fit and the patterns in the weighted residuals suggest that model error is likely in the northern part of the basin. This is not surprising because recent geologic studies (Smith and Kuhle, 1998) aimed at characterizing this part of the basin suggest that there is considerably more heterogeneity in geologic conditions than is represented by the simple hydraulic-conductivity zonation in the model (fig. 9). In the northwestern part of the basin, the magnitude and sign of several weighted head residuals differ among calibrations 4 and 6 . These differences result from the different hydraulic-conductivity zonation in the western part of the basin of subsurface configurations 4 and 6 as well as the different optimal parameter estimates of $\mathrm{K}_{\mathrm{LSF}-\mathrm{Z}}$ and $\mathrm{RM}_{\mathrm{Jemez}}$ in calibrations 4 and 6 . However, the fit to the data in this part of the basin is not obviously superior in either of the calibrations.

In 1992 and 1994, weighted hydraulic-head residuals for both calibrations 4 and 6 at the deep wells in the Albuquerque area are generally larger in absolute value than in the 1950's (fig. 18). The worse fit in the 1990 's is likely because of increased model error related to the representation of pumpage in the model. Ground water is withdrawn at additional locations and in greater quantities in the 1990's than in the 1950's. Potential sources of model error likely to increase as total pumpage increases are (1) the temporal averaging of ground-water withdrawals to obtain the mean annual pumpage used in the simulation, (2) the spatial averaging of pumpage from several wells located in a single model cell, and (3) the assumed contribution to the total pumping rate from different model layers for wells with long screened intervals. 


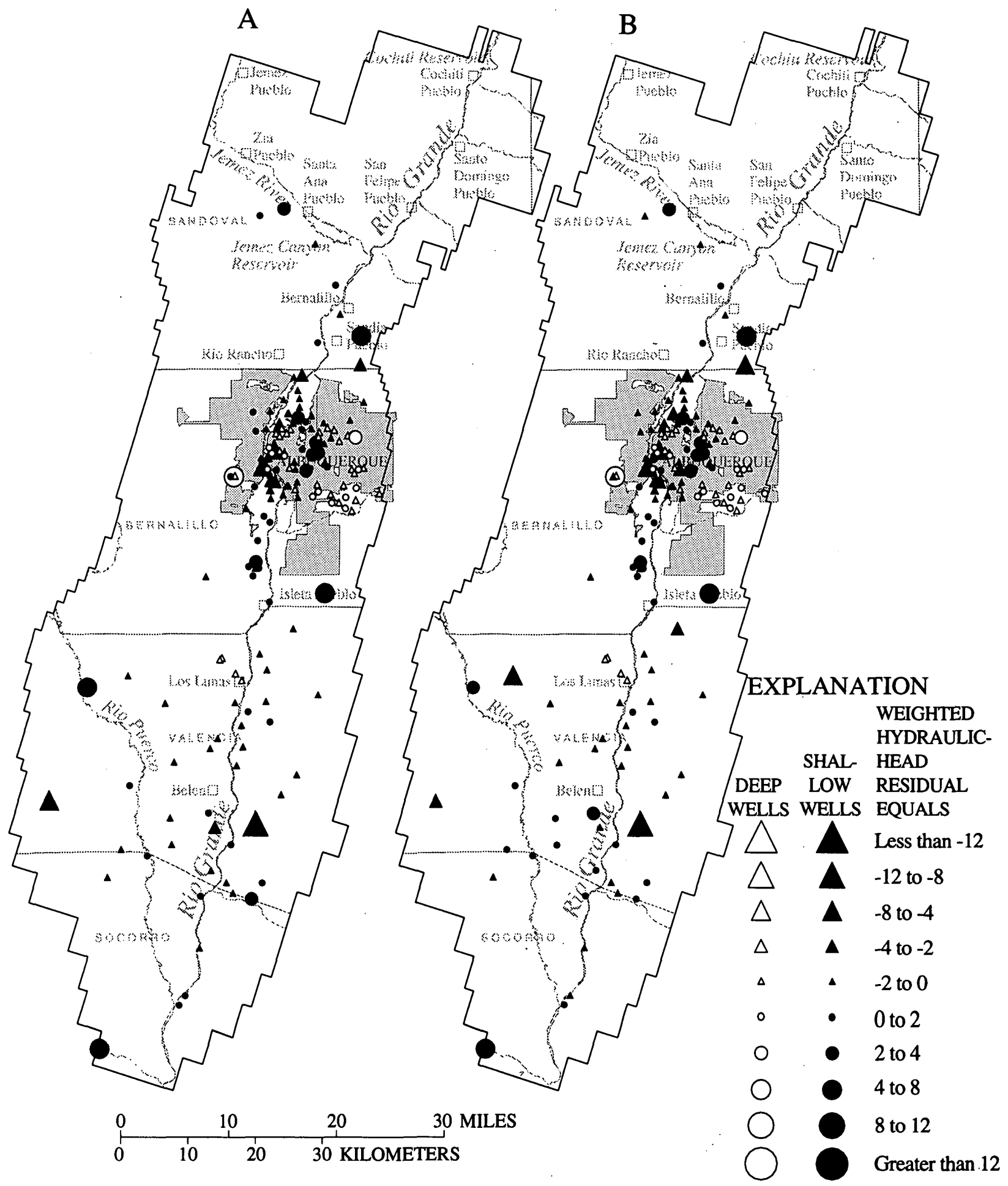

Figure 18. Spatial distribution of weighted hydraulic-head residuals during the 1950's for (A) calibration 4 and (B) calibration 6, during 1992 for (C) calibration 4 and (D) calibration 6, and during 1994 for (E) calibration 4 and $(F)$ calibration 6 . 


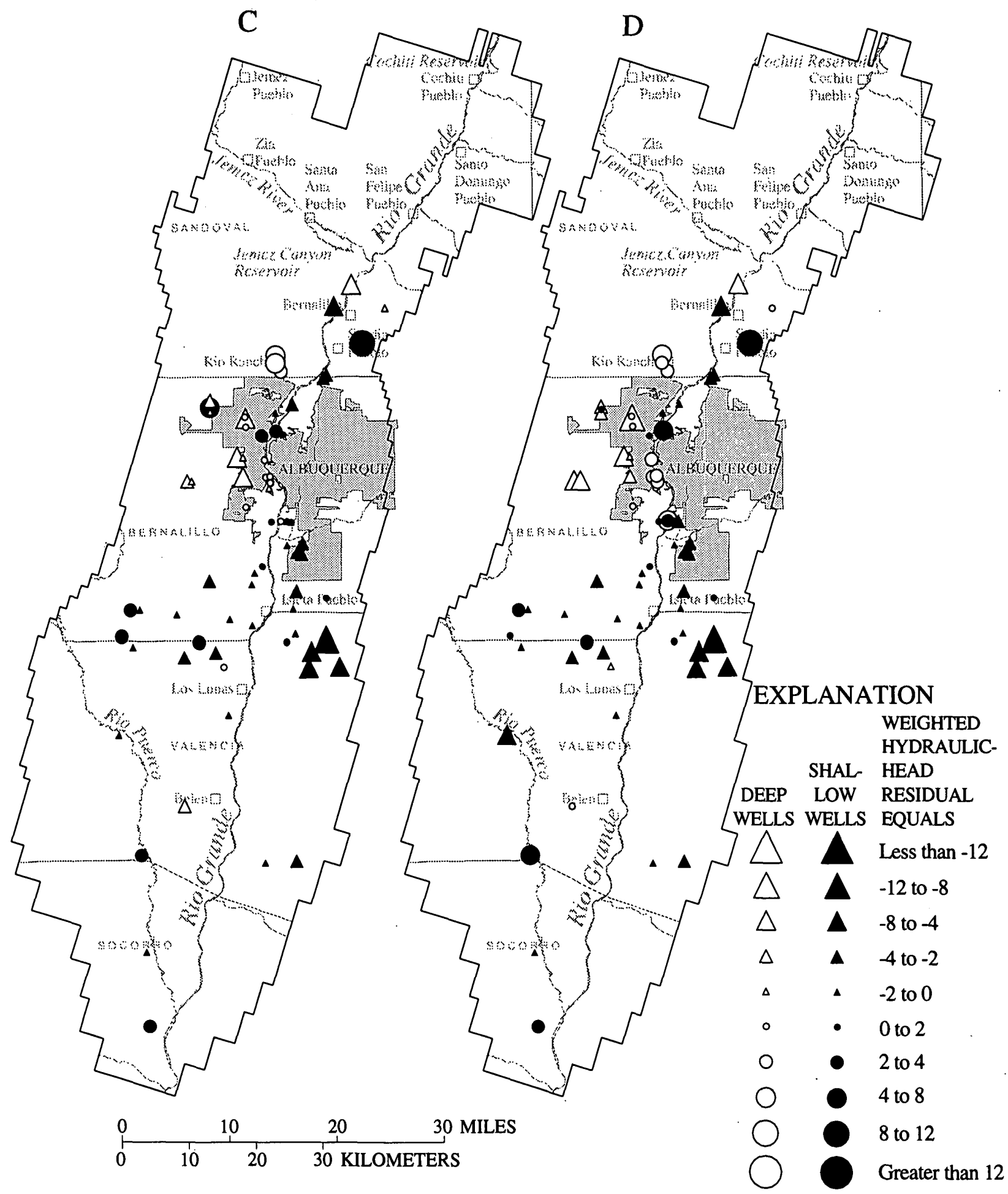

Figure 18 (Continued). Spatial distribution of weighted hydraulic-head residuals during the 1950's for (A) calibration 4 and (B) calibration 6, during 1992 for (C) calibration 4 and (D) calibration 6, and during 1994 for (E) calibration 4 and $(F)$ calibration 6. 


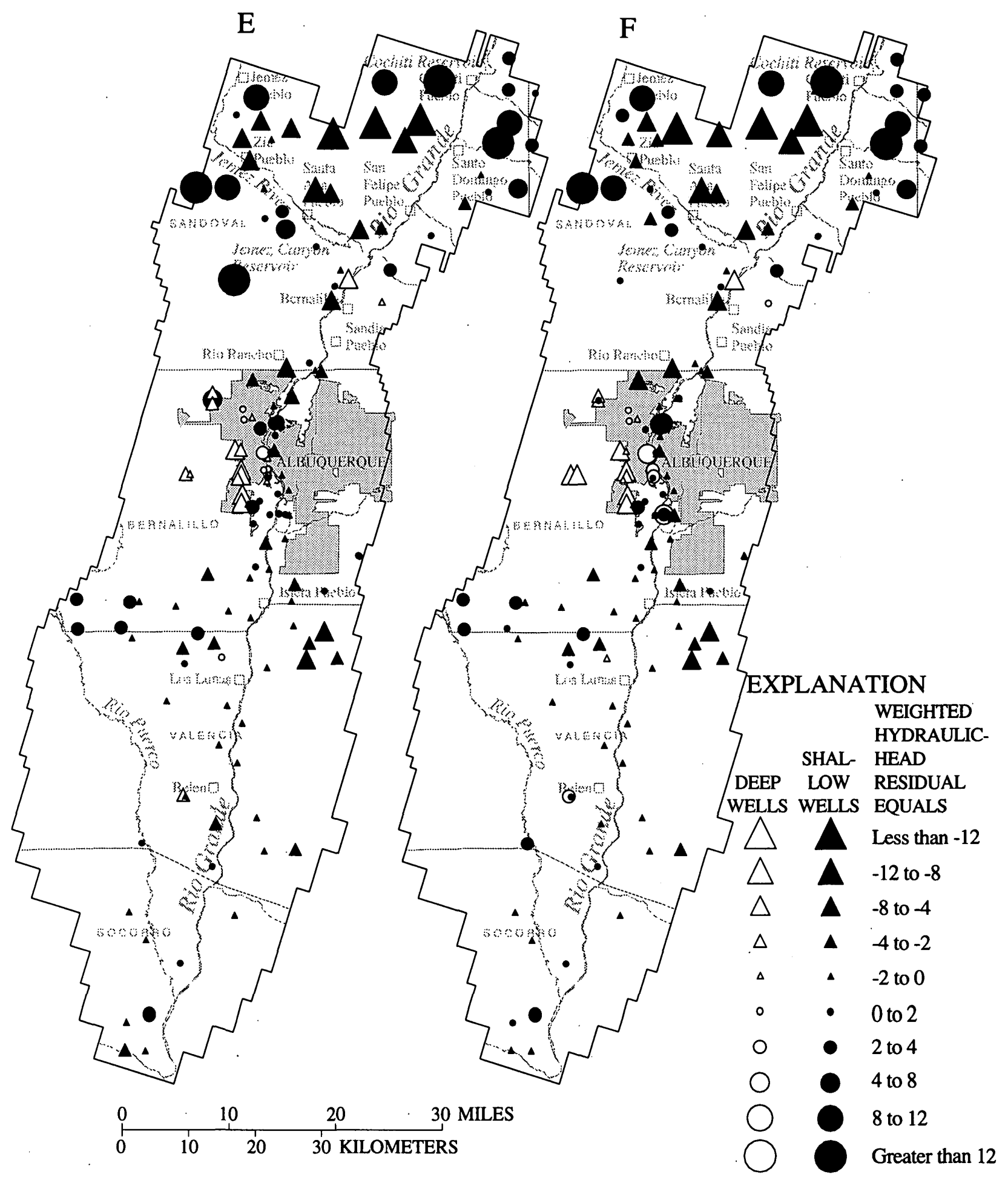

Figure 18 (Concluded). Spatial distribution of weighted hydraulic-head residuals during the 1950's for (A) calibration 4 and (B) calibration 6, during 1992 for (C) calibration 4 and (D) calibration 6, and during 1994 for $(E)$ calibration 4 and $(F)$ calibration 6. 
In 1992 and 1994, weighted residuals at the deep wells in the inner valley are generally smaller in absolute value in calibration 4 than in calibration 6 . This difference between the two calibrations is most likely because the optimal estimate of $A_{V}$ differs between the two calibrations. The positive weighted hydraulic-head residuals are larger in calibration 6 compared with calibration 4 because simulated heads at the deep wells in the Albuquerque area are lower in calibration 6 than in calibration 4. Compared with calibration 4, the larger vertical anisotropy estimate in calibration 6 results in less connection of the river and shallow ground-water flow system to the deeper flow system and thus greater pumping-induced drawdown in the deep system. At the deep screened intervals of piezometers WM1 A and WM2 (fig. 12) west of Albuquerque, weighted residuals are also generally smaller in absolute value in calibration 4 compared with calibration 6 . Here, the difference in weighted residuals between calibrations 4 and 6 results because addition of the west basin high-K zone to the model results in lower simulated hydraulic heads at WM1A and WM2 and a better match to observed heads than does addition of the low-K fault zone.

The clustering of the groups of negative and positive weighted residuals at the deep wells in the Albuquerque area (fig. 18C-F) is an indication of likely model error. One possible source of error may be related to the homogeneity of the hydraulic-

conductivity zonation in the vicinity of these clusters of same-sign residuals. In both subsurface configurations 4 and 6, almost all the deep wells in the inner valley and the southwestern part of Albuquerque shown in figures $18 \mathrm{C}-\mathrm{F}$ are located in the USF1 hydraulic-conductivity zone in layers 4 and 5 of the model and in the MSF hydraulic-conductivity zone in layer 6 . Changing the hydraulic conductivity of one of these zones to improve the fit at the cluster of wells where simulated head is too high is likely to worsen fit at the cluster of wells where simulated head is too low. If true geologic conditions are more heterogeneous, each group of wells associated with a cluster of same-sign residuals might penetrate a different hydrogeologic zone. In the model, this representation of subsurface conditions would allow for improvement in both the model fit and the distribution of residuals.

The temporal distribution of weighted hydraulichead residuals in calibrations 4 and 6 at the hydrograph wells and piezometers is shown in figure 19. All of these weighted residuals are less than 10.5, in absolute value. The weighted residuals should ideally show no temporal trends, but in both calibrations the absolute values of the weighted residuals increase somewhat with time. This characteristic of the plot is due partially to the circumstance that some wells have hydraulichead measurements only at later times in the simulation.

\section{Simulated and Observed Hydraulic Heads}

Although examination of weighted residuals allows for analysis of the fit of the model to the calibration data relative to the assumed precision of the measurements, a comparison of the fit of simulated and observed conditions that is unaffected by the weighting is also useful because some judgment is involved in selecting the weights. Observed hydraulic heads are compared to simulated hydraulic heads in model runs with layers 2 and 3 represented as convertible, which is a more accurate representation of the true ground-water flow system than the representation of these layers as confined in the regression runs. Simulations with the convertible-layer representation are done for the model with subsurface configurations 4 and 6 and the parameter estimates from, respectively, calibrations 4 and 6. These model simulations are referred to as simulations 4 and 6 to distinguish their results from those of calibrations 4 and 6 . At hydraulic-head observation locations included in the calibration data set, hydraulic heads in simulations 4 and 6 differ by no more than $5 \mathrm{ft}$ from simulated heads in, respectively, calibrations 4 and 6 because of the choice of data to retain in the calibration data set. Simulated hydraulic heads are also compared to the head observations that were removed from the calibration data set because of differences of more than $5 \mathrm{ft}$ between simulated head in the models with the confined-layer and convertiblelayer representations.

Overall, the model fit to the head observations that were removed from the calibration data set is not significantly different from the fit to the calibration data that was achieved by application of nonlinear regression. To illustrate this, the equivalent standard error for simulations 4 and 6 is calculated with equation 4 by including the calibration data as well as the observations that were removed. Weights are assigned to these additional observations in the same manner as for the calibration data. The resulting equivalent standard error for simulations 4 and 6 is 3.5 and 3.8, respectively. These values are about 3 to 9 percent larger than the standard errors of regression for calibrations 4 and 6 (table 9). 


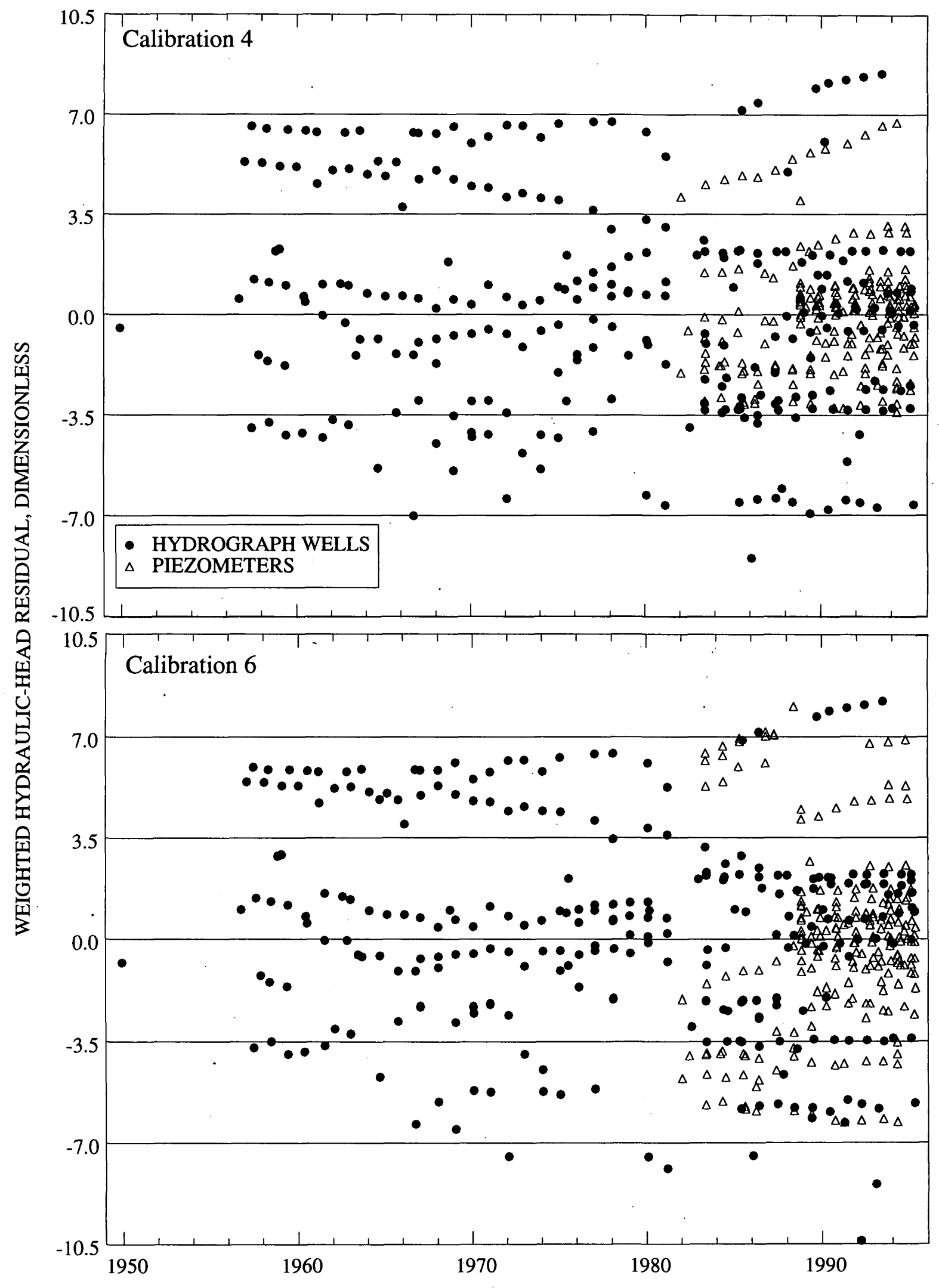

Figure 19. Temporal distribution of weighted hydraulic-head residuals.

58 Application of Nonlinear-Regression Methods to a Ground-Water Flow Model of the Albuquerque Basin, New Mexico 
Differences between simulated and observed hydraulic heads in the 1950's are plotted at the same set of locations shown in figure 18A-B, because no data from the 1950's were removed from the calibration data set on account of differences between model simulations with the confined-layer and convertiblelayer representations (fig. 20A-B). For this time period, head differences are less than $20 \mathrm{ft}$ at most shallow and deep wells in simulations 4 and 6 .

Basinwide maps of differences between simulated and observed hydraulic heads in 1992 and 1994 (figs 20C-F) include differences at several locations in the Albuquerque area for which there are no weighted residuals plotted in figure $18 \mathrm{C}-\mathrm{F}$. These are the locations for which hydraulic-head observations were removed from the calibration data set. Head differences in the Albuquerque area are plotted at a larger scale in figure 21. At the shallow wells in 1992 and 1994, there are several locations in the basin interior where the difference between simulated and observed hydraulic heads in both simulations 4 and 6 is less than $20 \mathrm{ft}$ in absolute value. In the northern part of the basin and near Cat Mesa Fault, head differences are commonly greater than $40 \mathrm{ft}$ in absolute value. As noted in the discussion of the weighted residuals, the large differences in the northern part of the basin are not surprising because of the likely oversimplified representation of subsurface conditions in this area. The large positive head differences at wells on the west side of Cat Mesa Fault (see fig. 3) near the intersection of the Rio Puerco and the western model boundary indicate that simulated hydraulic head is much too low on the west side of the fault. Although the hydraulic conductivity of the northern part of Cat Mesa Fault in all subsurface configurations was significantly reduced compared with the hydraulic conductivity specified in the model of Kernodle (1998), the fault representation in the model presented here still fails to reproduce observed upgradient hydraulic heads. The fit is not substantially better in simulation 6 compared with simulation 4 , indicating that reduction of the hydraulic conductivity of the West Atrisco Fault north of Cat Mesa Fault does not greatly improve the match.

There is a fairly even distribution of small and large differences between simulated and observed heads at the deep wells for 1992 and 1994 (fig. 21). Many differences are greater than $40 \mathrm{ft}$, but there are also many locations where the difference is much smaller, in areas where head observations were retained in the calibration data set as well as in areas where head observations were omitted. Overall, the distribution of positive and negative head differences at the deep wells is similar in simulations 4 and 6 . The primary difference between the two simulations is that generally simulated heads are higher in simulation 4 , which results in larger (in absolute value) negative head differences and smaller positive head differences.

Simulations 4 and 6 produce a similar fit to observed heads at the hydrograph wells (fig. 22). At most wells, the difference between hydraulic head in either simulation and observed head is greater than the difference between hydraulic head in the two simulations. The greatest differences between hydraulic heads in simulations 4 and 6 occur at wells $\mathrm{H}$ and $\mathrm{K}$, where the fit at later times is better for simulation 4, and at wells $\mathrm{G}, \mathrm{O}$, and $\mathrm{S}$, where the fit is better for simulation 6 . Overall, however, neither of the simulations provides an obviously better fit to the hydrograph well observations as a whole. The largest differences between simulated and observed heads are at wells E, N, and W. Measured heads at well W are about $100 \mathrm{ft}$ lower than those at well $\mathrm{E}$, about 3 miles distant. In the simulations, the head difference is only about 10 to $30 \mathrm{ft}$, resulting in a poor match to observed heads at both wells. In the model, both these wells are in the USF2 hydraulic-conductivity zone, and no faults are located between them. Thus, simulating a large head decline over the fairly short distance separating the wells is difficult. Subsurface conditions in the vicinity of these two wells likely are not as homogeneous as portrayed in the model. At well N, the temporal trend of observed head is matched, although the magnitude of simulated heads is about 30 to $50 \mathrm{ft}$ too large.

At wells $\mathrm{J}$ and $\mathrm{L}$, the fit of simulated and observed heads is clearly worse at times for which observations are not included in the calibration data set, compared with the fit at times for which observations are included (fig. 22). Although simulated heads remain within about $10 \mathrm{ft}$ of observed heads at the later times, this result highlights a major limitation of the work presented here, in that the regression model does not support simulations with convertible layers. 


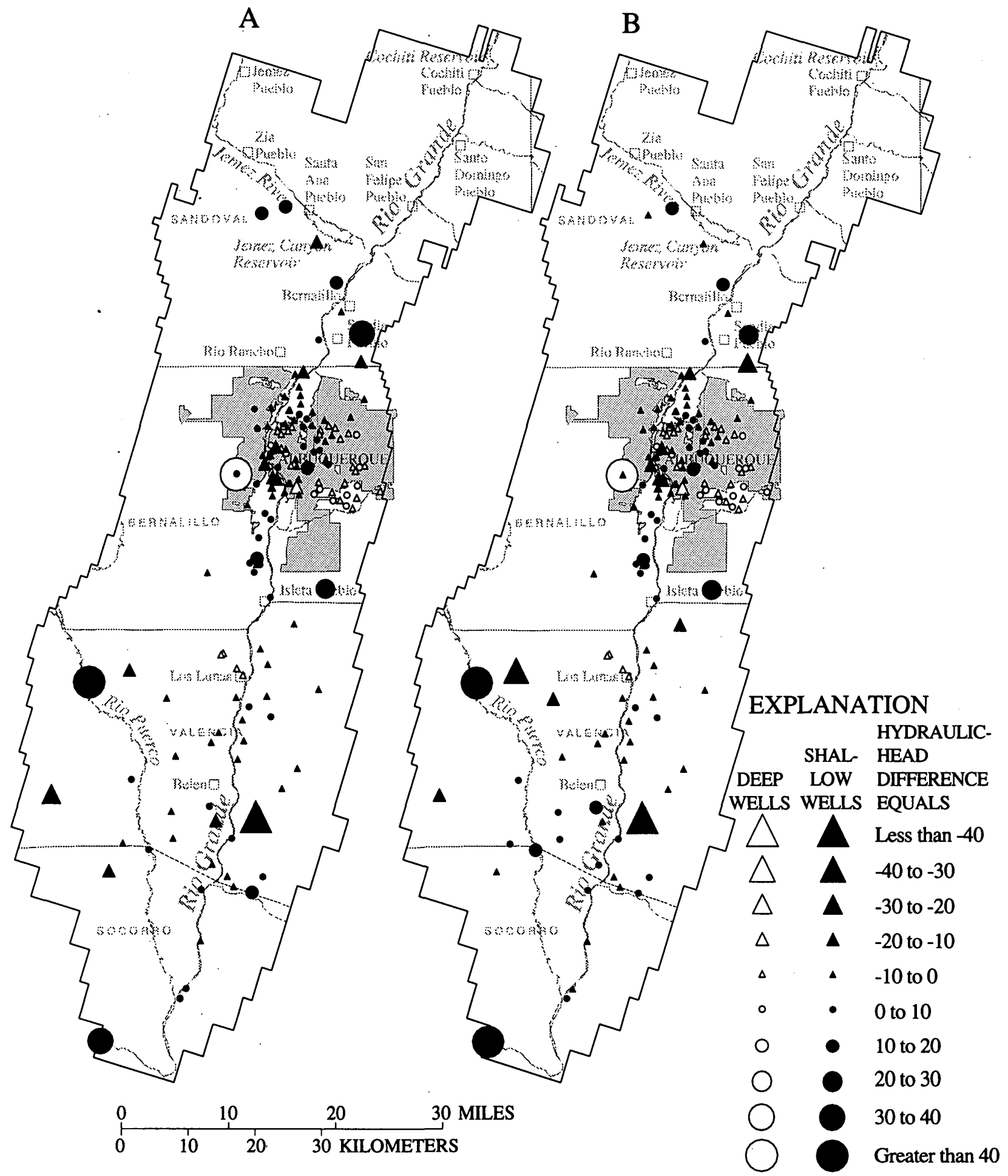

Figure 20. Spatial distribution of differences between simulated and observed hydraulic heads during the 1950's for (A) simulation 4 and (B) simulation 6, during 1992 for (C) simulation 4 and (D) simulation 6, and during 1994 for $(E)$ simulation 4 and $(F)$ simulation 6. 


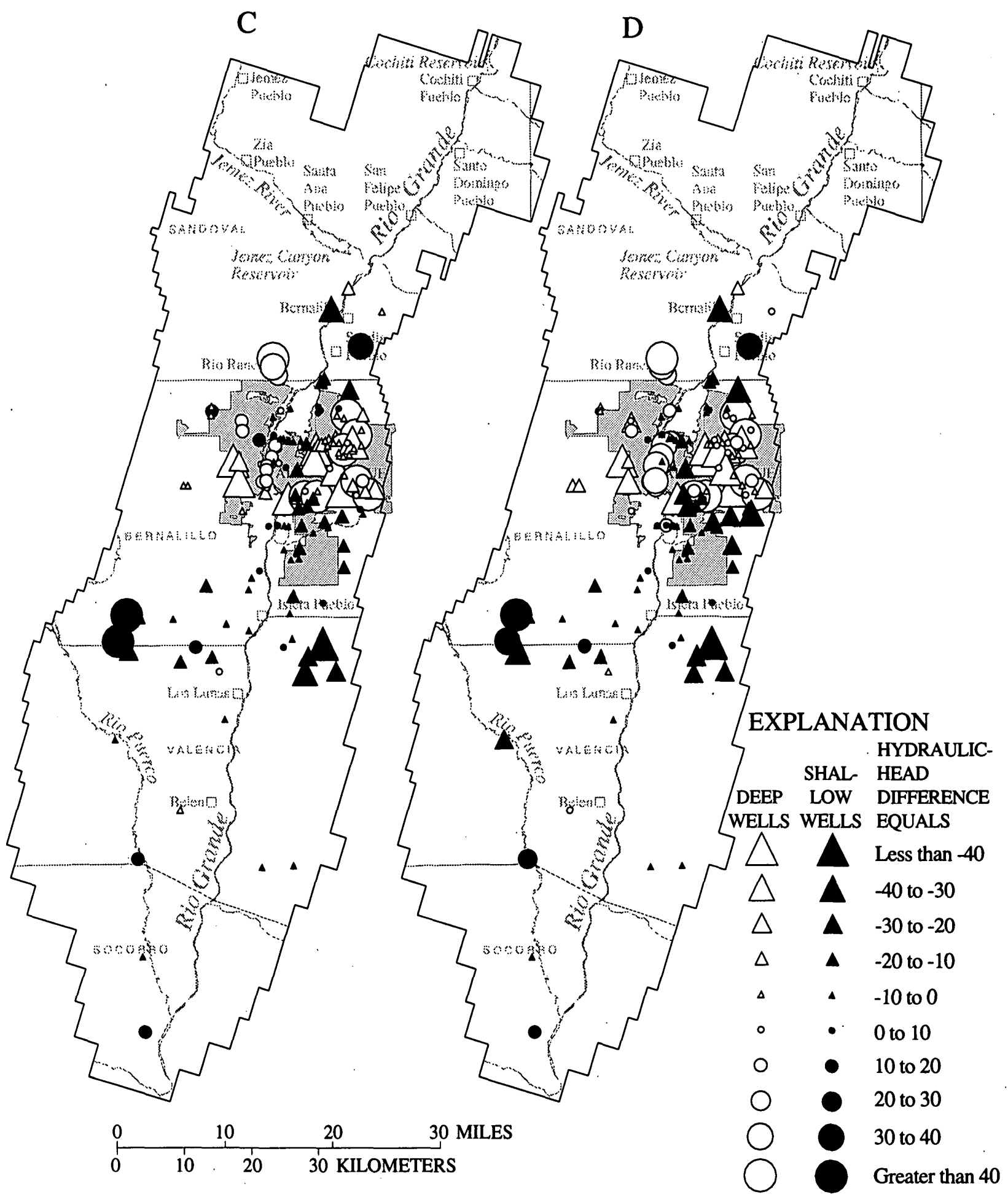

Figure 20 (Continued). Spatial distribution of differences between simulated and observed hydraulic heads during the 1950's for (A) simulation 4 and (B) simulation 6, during 1992 for (C) simulation 4 and (D) simulation 6, and during 1994 for $(E)$ simulation 4 and $(F)$ simulation 6. 


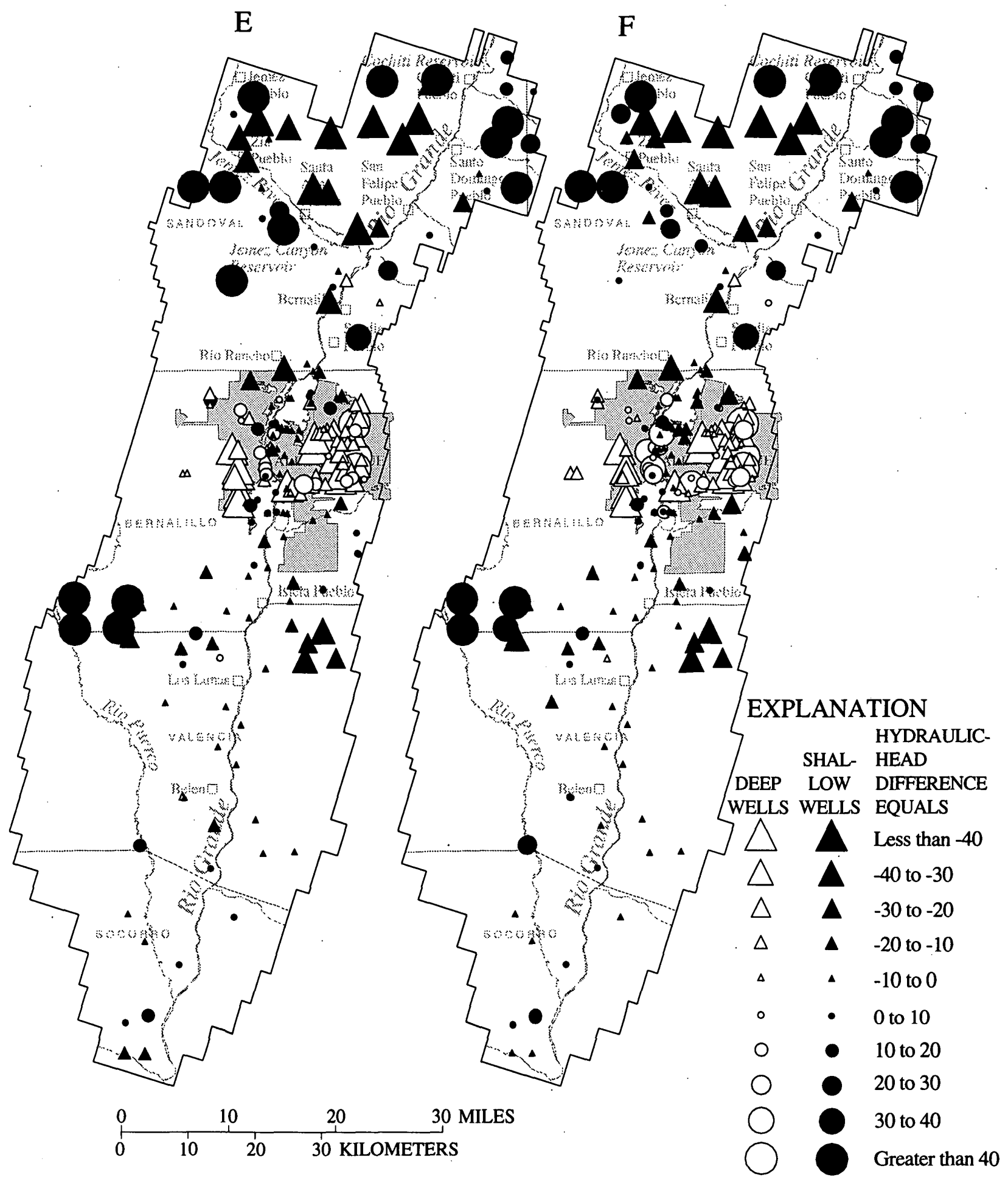

Figure 20 (Concluded). Spatial distribution of differences between simulated and observed hydraulic heads during the 1950's for (A) simulation 4 and $(B)$ simulation 6, during 1992 for $(C)$ simulation 4 and (D) simulation 6, and during 1994 for $(E)$ simulation 4 and $(F)$ simulation 6. 


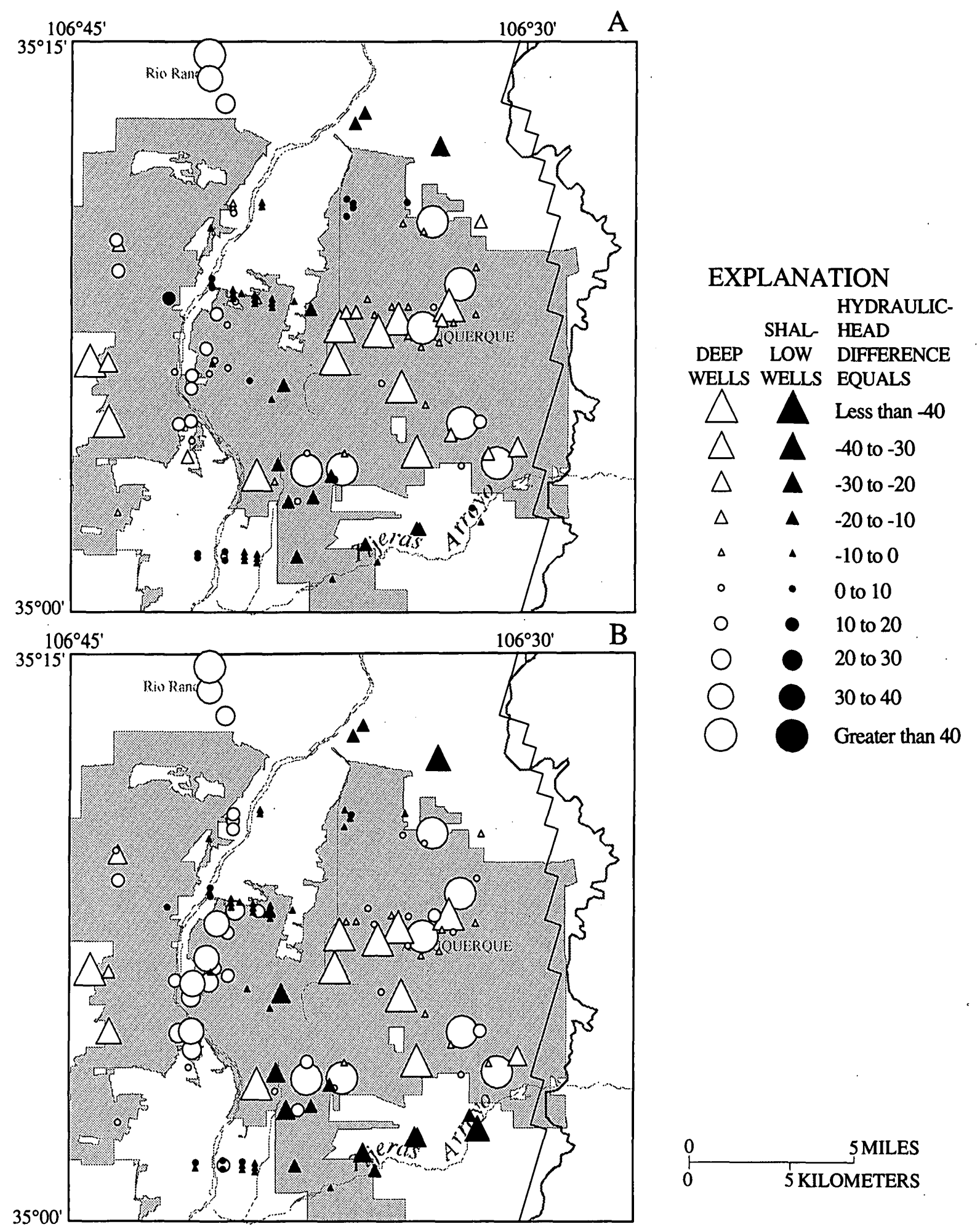

Figure 21. Spatial distribution of differences between simulated and observed hydraulic heads in the Albuquerque area during 1992 for (A) simulation 4 and (B) simulation 6, and during 1994 for (C) simulation 4 and (D) simulation 6. 


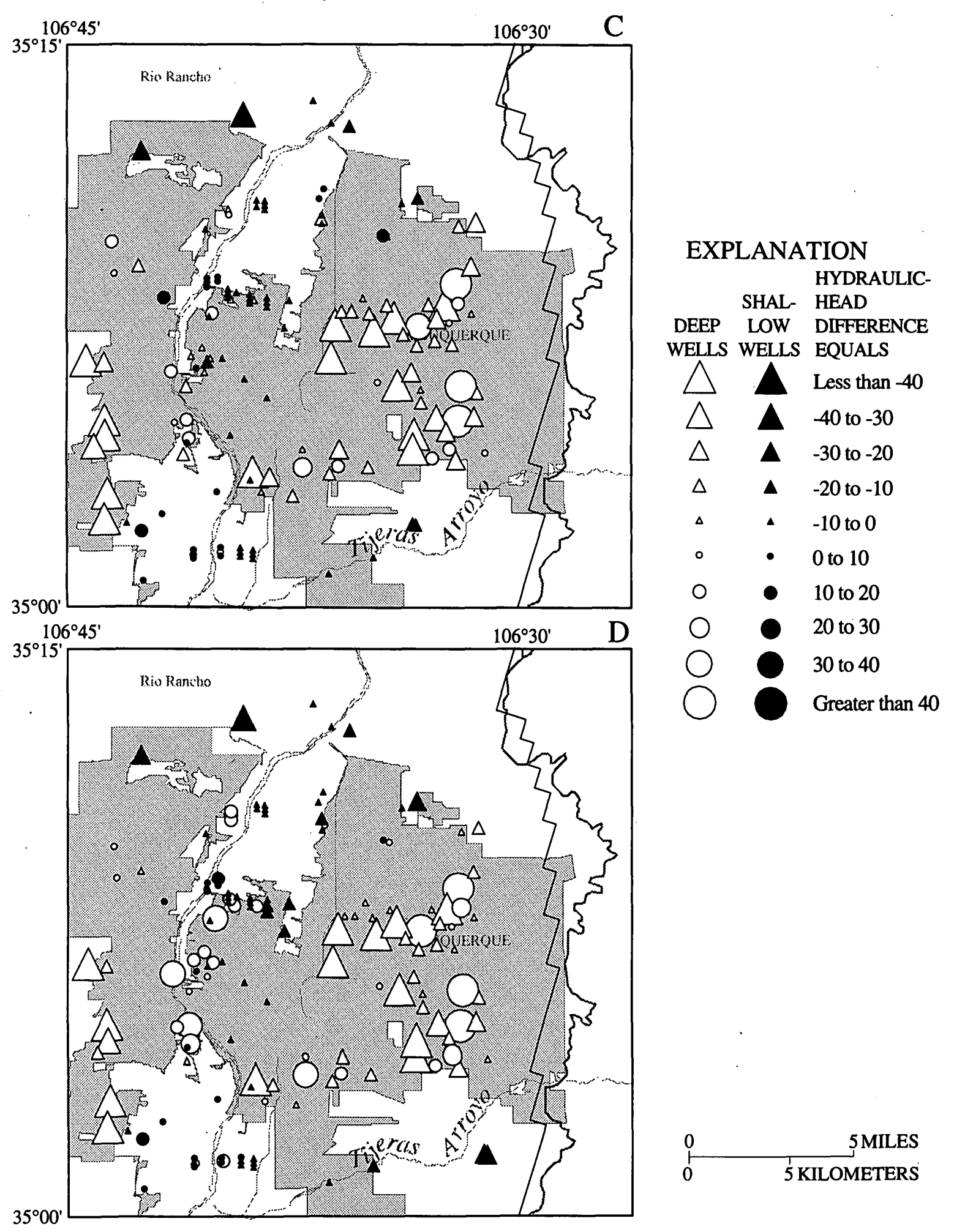

Figure 21 (Concluded). Spatial distribution of differences between simulated and observed hydraulic heads in the Albuquerque area during 1992 for (A) simulation 4 and (B) simulation 6, and during 1994 for (C) simulation 4 and (D) simulation 6. 


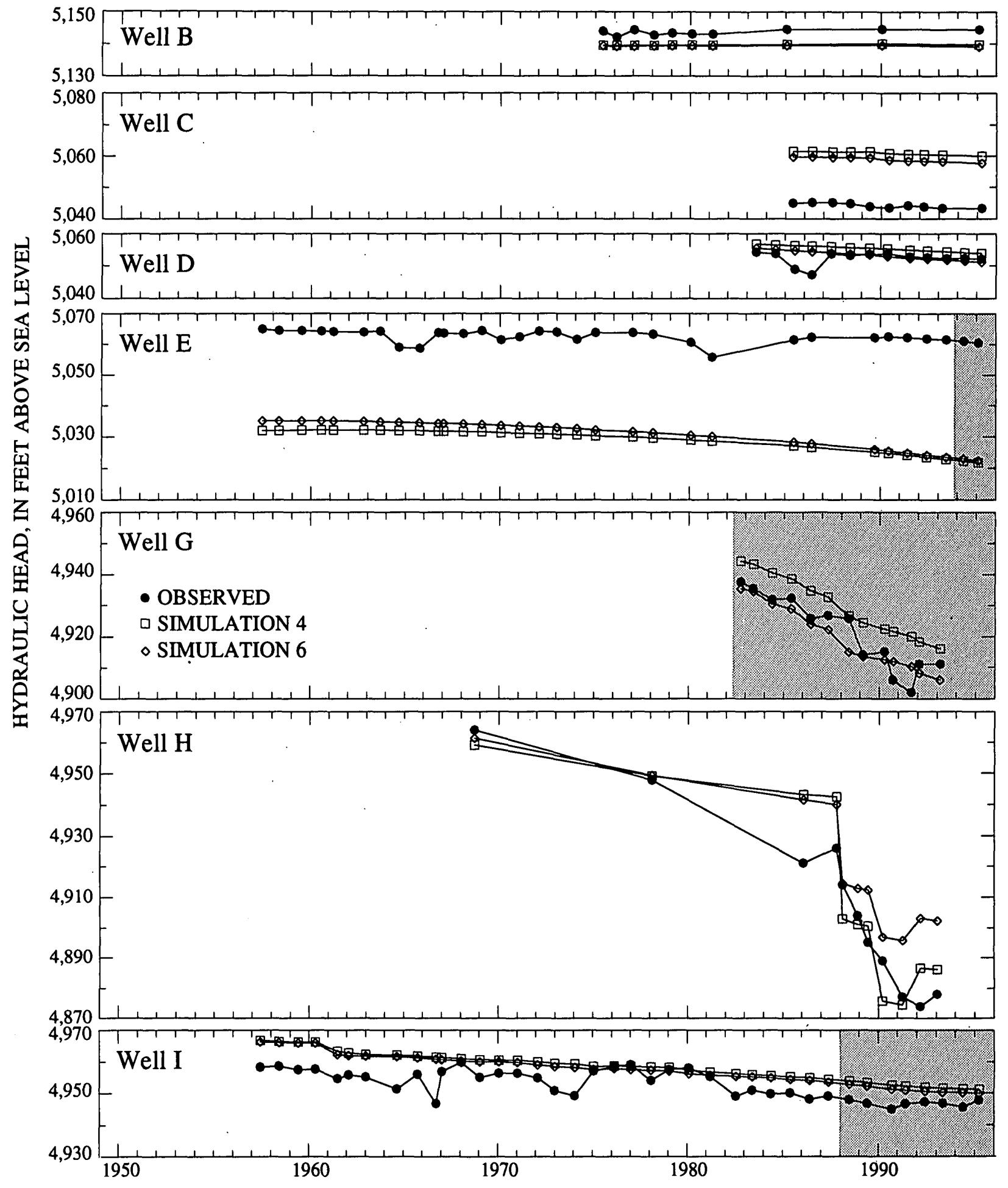

Figure 22. Observed and simulated hydraulic heads at hydrograph wells. Shaded regions show times at which observed hydraulic heads are not included in the calibration data set. Well locations are shown in figure 11. 


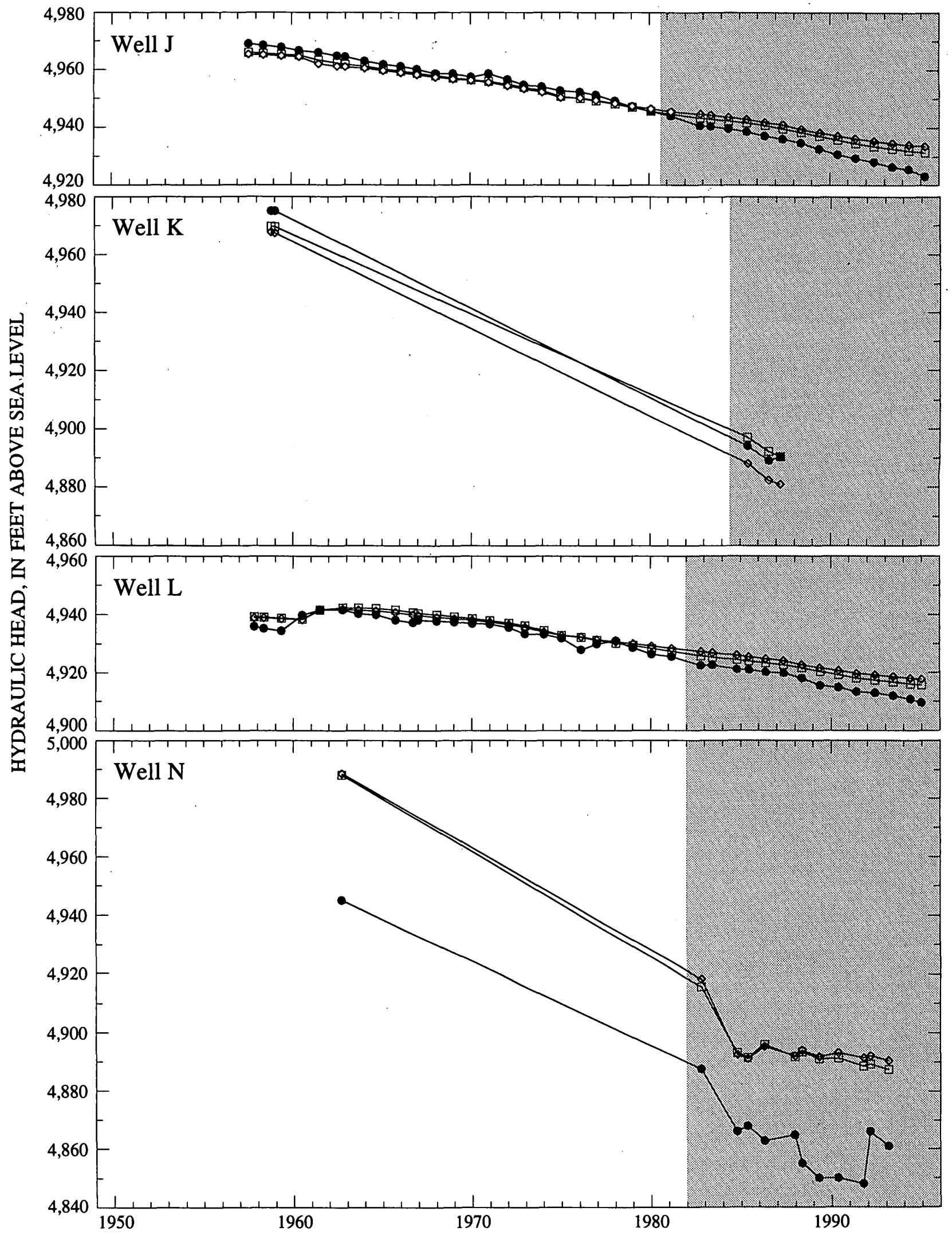

Figure 22 (Continued). Observed and simulated hydraulic heads at hydrograph wells. Shaded regions show times at which observed hydraulic heads are not included in the calibration data set. Well locations are shown in figure 11. 


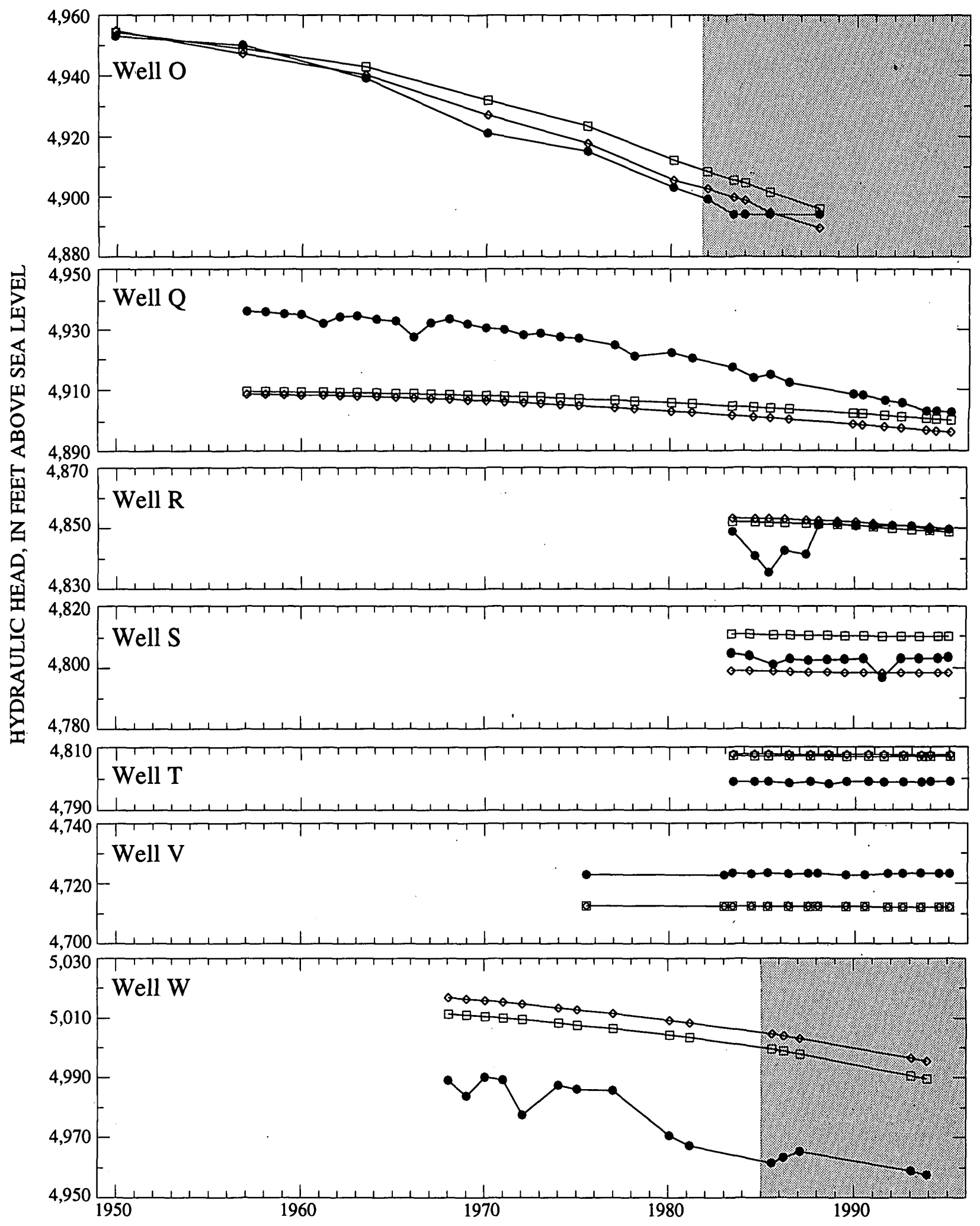

Figure 22 (Concluded). Observed and simulated hydraulic heads at hydrograph wells. Shaded regions show times at which observed hydraulic heads are not included in the calibration data set. Well locations are shown in figure 11. 
Comparison of hydraulic heads in simulations 4 and 6 with observed heads at the piezometer nests (fig. 23) illustrates that neither of the simulations produces an obviously better fit to the piezometer data as a whole. The data suggest that vertical anisotropy is spatially variable because the observed vertical hydraulic gradient is small at some piezometer nests and much larger at other nests. At piezometer nests with small observed vertical gradients, simulation 4, with an estimate of $A_{V}$ equal to 330 (table 7), tends to produce a better fit to the gradient than does simulation 6, with an estimate of $A_{V}$ equal to 1,200. At most piezometers, however, neither simulation produces a very close match to the vertical hydraulic gradients. At piezometers near Paseo del Norte Bridge (PDN1-3), the fit is somewhat better for simulation 6 (fig. 23). The observed vertical hydraulic gradients at most of the piezometers near Montaño Boulevard (MON1-5) and the Rio Bravo Bridge (RB1 and RB3-5) are small, and consequently vertical gradients in simulation 4 are generally closer to the observed conditions. Conditions at MON6 are shown in table 10 because there is a measurement only in 1995; at this piezometer nest simulation 4 also produces the best fit to the observed vertical hydraulic gradient. Piezometer nests WM2 and WM3 exhibit moderate to large head differences between the upper interval and the lower two intervals and simulation 6 provides a better match to the observed vertical gradients (fig. 23). At WM3, however, the overall fit to the magnitude of the hydraulic-head data is better in simulation 4 . At WM1A, the fit in both simulations to the vertical hydraulic gradient is fair, but simulated hydraulic heads are somewhat higher than observed heads.

At the $\mathrm{ZP}$ and SAP piezometer nests in the northern part of the basin, the fit to the data is poor (table 10). Hydraulic heads in simulations 4 and 6 are $51 \mathrm{ft}$ lower to $22 \mathrm{ft}$ higher than observed heads in intervals of piezometer ZP and are 18 to $83 \mathrm{ft}$ lower than observed heads in intervals of piezometer SAP. Also, the observed vertical hydraulic gradients suggest that ground water moves from the deeper part of the basin upward to shallower depths in the vicinity of these piezometers, whereas simulations 4 and 6 both produce downward gradients. The observed upward flow suggests that ground water may be discharging to the Jemez River near these wells. Recharge imposed along the Jemez River is the primary source of inflow to the model in the northwestern part of the model domain and under this circumstance, it is unlikely that this upward flow can be reproduced. The observed vertical hydraulic gradients in piezometers ZP and SAP point to the possibility that underflow at depth from areas outside the Albuquerque Basin may be a larger source of inflow to the northwestern part of the basin than is currently simulated in the ground-water flow model. Recent analyses of carbon-14 content in ground-water samples support this possibility, in that the data suggest that underflow from areas outside the Albuquerque Basin could be a major source of ground water in the northwestern part of the basin (W.E. Sanford, Hydrologist, U.S. Geological Survey, oral commun., 1998).

\section{Weighted Flow Residual and Simulated Flow}

The weighted flow residual in calibrations 4 and 6 is -0.9 and -0.6 , respectively. These values are small because of the small weight assigned to the flow observation. The simulated equivalent of the flow observation in calibrations 4 and 6 is, respectively, 53,900 and 45,800 acre-ft/yr. These simulated flows are 86 and 58 percent larger than the 29,000 -acre-ft/yr flow observation included in the regression. Parameter estimates that improve the overall fit to the hydraulichead data are those that result in a simulated flow over the gaged reach that is much larger than the observed flow used in the regression. Because the weighted flow residual is small even if the simulated flow poorly matches the observed flow, the flow observation does not have a large influence on the parameter estimates, and the optimal estimates are those that result in a large difference between simulated and observed flow. However, because of the large uncertainty associated with the flow observation, the simulated flow in the calibrations is well within the 95-percent confidence interval that was assumed for purposes of calculating the weight.

The simulated equivalent of the flow observation in simulations 4 and 6 (with model layers 2 and 3 represented as convertible) is, respectively, 46,800 and $39,800 \mathrm{acre}-\mathrm{ft} / \mathrm{yr}$. These simulated flows are 61 and 37 percent larger than the observed flow used in the regression. The simulated flow in the model with convertible layers is a better indication of model fit because this model-layer representation more closely mimics the behavior of the true ground-water flow system. 


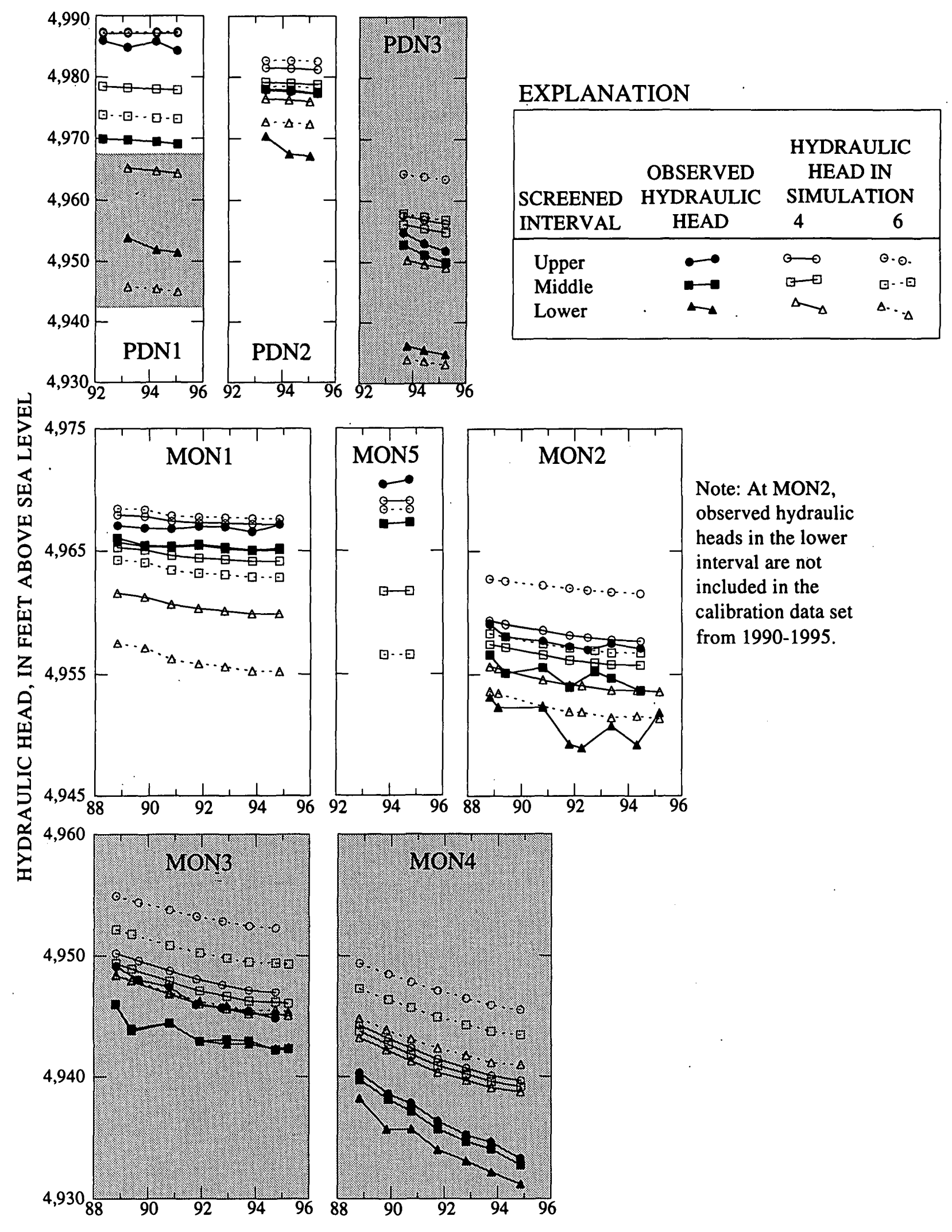

Figure 23. Observed and simulated hydraulic heads at piezometer nests. Shaded regions denote times and locations at which observed hydraulic heads are not included in the calibration data set. Piezometer locations are shown in figure 12. 


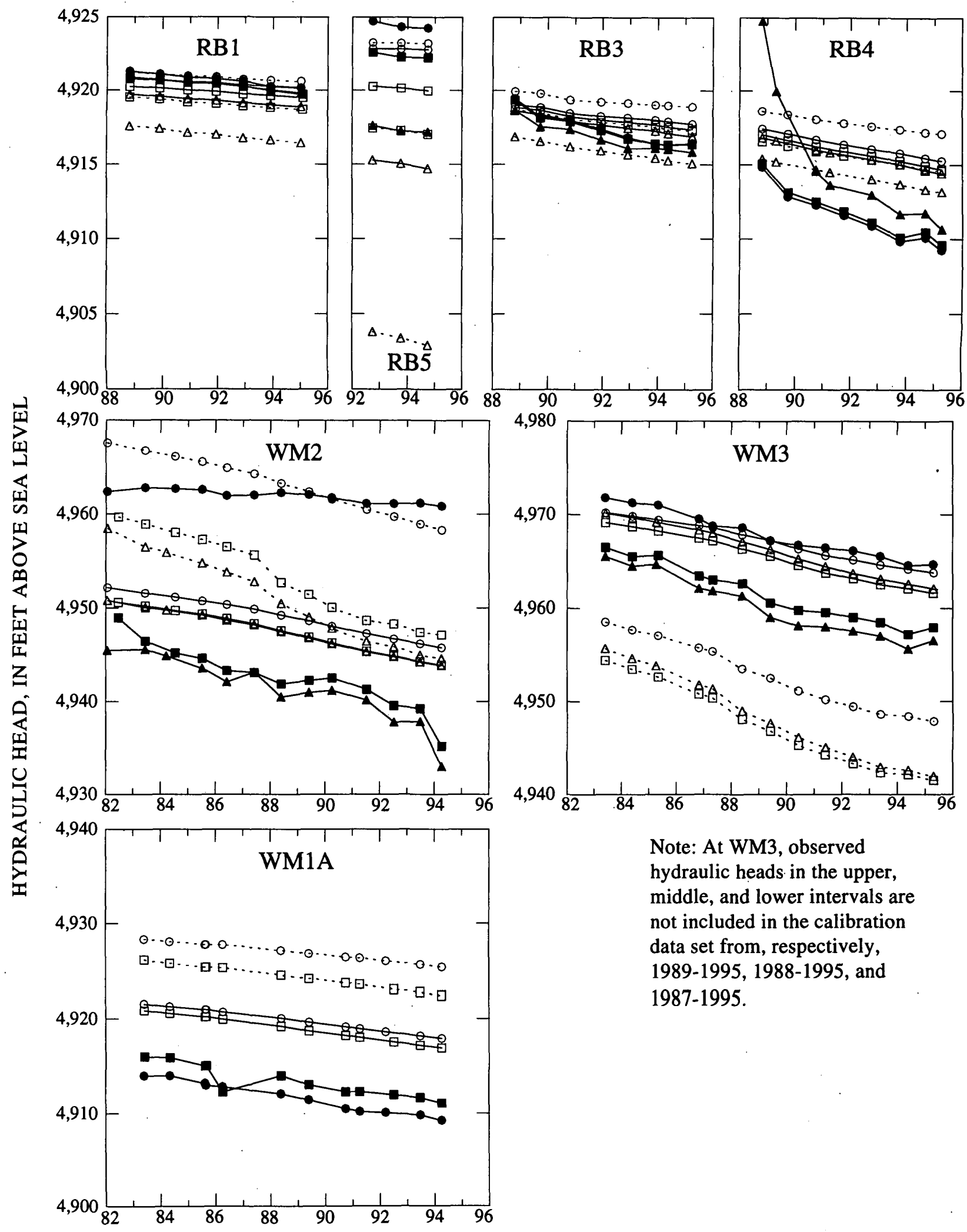

Figure 23 (Concluded). Observed and simulated hydraulic heads at piezometer nests. Shaded regions denote times and locations at which observed hydraulic heads are not included in the calibration data set. Piezometer locations are shown in figure 12. 
Table 10. Simulated hydraulic heads at piezometers MON6, ZP, and SAP

[Hydraulic head in feet above sea level]

\begin{tabular}{|c|c|c|c|c|c|c|}
\hline \multirow[b]{2}{*}{ Piezometer } & \multirow[b]{2}{*}{$\begin{array}{c}\text { Primary model } \\
\text { layer } \\
\text { intersected by } \\
\text { screen }\end{array}$} & \multirow[b]{2}{*}{$\begin{array}{c}\text { Observed } \\
\text { hydraulic head }\end{array}$} & \multicolumn{2}{|c|}{ Simulation 4} & \multicolumn{2}{|c|}{ Simulation 6} \\
\hline & & & $\begin{array}{c}\text { Simulated } \\
\text { hydraulic head }\end{array}$ & $\begin{array}{c}\text { Difference } \\
\text { between } \\
\text { observed and } \\
\text { simulated head }\end{array}$ & $\begin{array}{c}\text { Simulated } \\
\text { hydraulic head }\end{array}$ & $\begin{array}{c}\text { Difference } \\
\text { between } \\
\text { observed and } \\
\text { simulated head }\end{array}$ \\
\hline MON6 & 3 & $4,946.6$ & $4,951.7$ & $5.1^{\circ}$ & $4,947.4$ & -0.8 \\
\hline MON6 & 4 & $4,937.5$ & $4,939.8$ & -2.3 & $4,920.0$ & 18 \\
\hline MON6 & 5 & $4,936.0$ & $4,939.9$ & -3.9 & $4,921.0$ & 15 \\
\hline MON6 & 6 & $4,935.1$ & $4,940.5$ & -5.4 & $4,923.0$ & 12 \\
\hline $\mathrm{ZP}$ & 2 & $5,377.5$ & $5,399.4$ & -22 & $5,382.4$ & -4.9 \\
\hline $\mathrm{ZP}$ & 3 & $5,382.0$ & $5,391.4$ & -9.4 & $5,361.7$ & 20 \\
\hline $\mathrm{ZP}$ & 5 & $5,382.6$ & $5,378.8$ & 3.7 & $5,331.5$ & 51 \\
\hline SAP & 1 & $5,291.2$ & $5,273.0$ & 18 & $5,271.6$ & 20 \\
\hline SAP & 4 & $5,305.1$ & $5,258.1$ & 47 & $5,250.2$ & 55 \\
\hline SAP & 5 & $5,316.6$ & $5,243.1$ & 74 & $5,233.7$ & 83 \\
\hline
\end{tabular}

\section{BASINWIDE SIMULATED CONDITIONS}

The basinwide simulated hydraulic heads and ground-water budget are presented for simulations 4 and 6. Identification of areas where hydraulic heads differ significantly between the two simulations and where head measurements are sparse or absent can help guide field investigations of the subsurface.

Comparison of the water budgets for the two simulations illustrates how the different features in subsurface configurations 4 and 6 and the different optimal parameter estimates of calibrations 4 and 6 affect simulated basinwide recharge and discharge. Major differences between simulated conditions in the model presented here and those in previous models of the basin are also noted.

\section{Hydraulic Heads}

The major differences in the steady-state water table for simulations 4 and 6 occur west of the Rio Grande in the central and northern parts of the basin (fig. 24). West of the low-K fault zone in subsurface configuration 6 , the water table is as much as $160 \mathrm{ft}$ higher in simulation 6 compared with simulation 4 .
East of this fault in the area occupied by the west basin high-K zone in subsurface configuration 4 , the water table is generally about 10 to $30 \mathrm{ft}$ higher in simulation 6 compared with simulation 4 . North of the low-K fault zone, the water table is as much as $140 \mathrm{ft}$ higher in simulation 6 except along the Jemez River, where. heads are as much as $20 \mathrm{ft}$ higher in simulation 4 because the estimate of $\mathrm{RM}_{\mathrm{Jemez}}$ is much larger in calibration 4 compared with calibration 6 . East of the Rio Grande, the difference in the steady-state water table for the two simulations is generally less than $5 \mathrm{ft}$.

The primary difference in the pattern of steadystate ground-water flow through the basin is that in simulation 4, a trough in ground-water levels in the western part of the basin is partially formed, resulting in a component of ground-water movement from the inner valley of the basin toward the west basin high- $K$ zone (fig. 24). In simulation 6, a trough-shaped feature in the water table is not produced and ground water between the low- $\mathrm{K}$ fault zone and the inner valley moves in a mostly southerly direction. Ground-water flow directions are also different west of the location of the low-K fault zone in subsurface configuration 6. Here, flow directions are generally to the east in simulation 4 but more southerly in simulation 6 . 


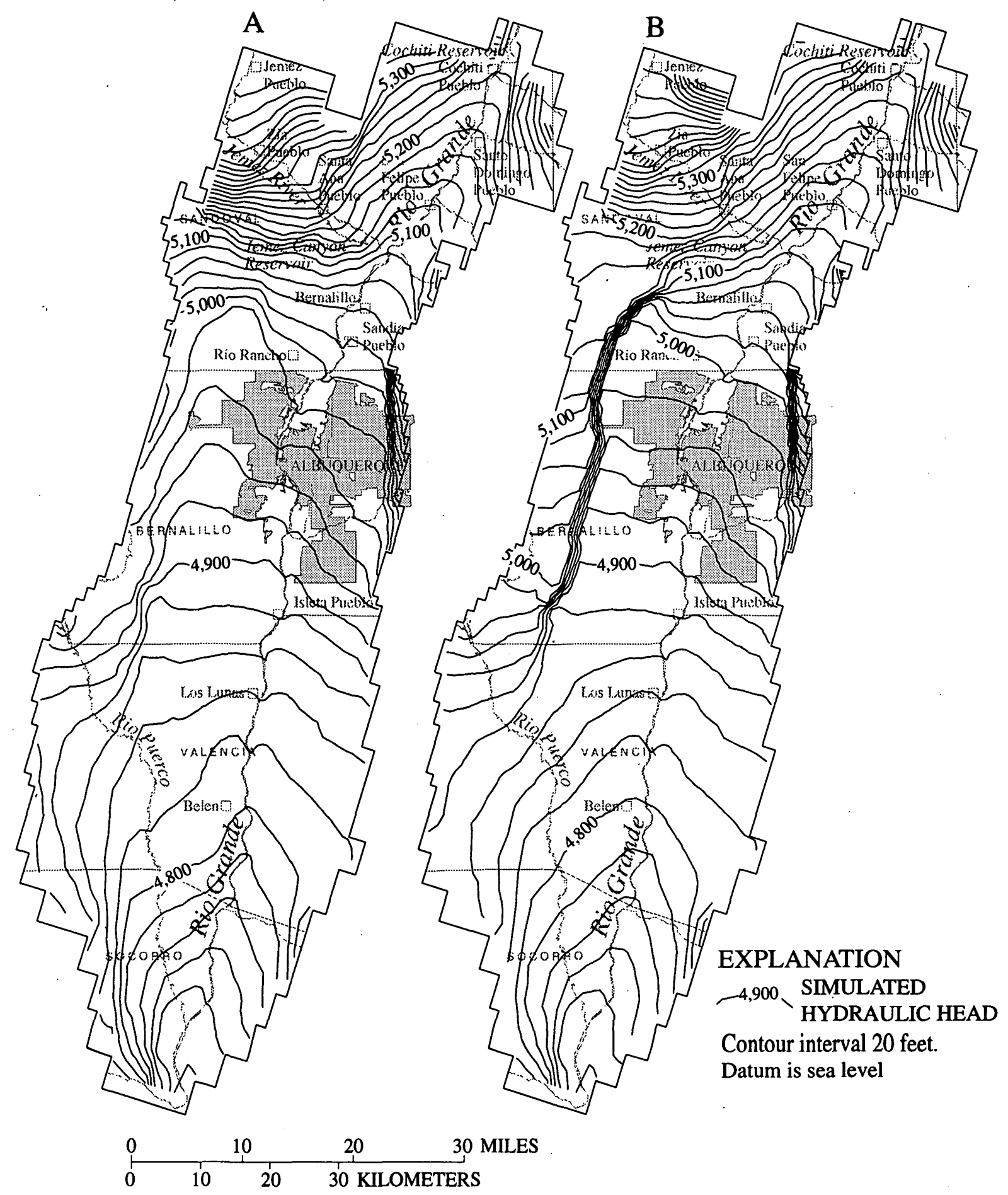

Figure 24. Simulated steady-state water table in (A) simulation 4 and (B) simulation 6. 
In 1995, the differences in the water table between simulations 4 and 6 east of the low-K fault zone in subsurface configuration 6 are not as great as at steady state because pumping in the western part of Albuquerque lowers water levels in simulation 6 (fig. 25 ). In the area of maximum drawdown in east Albuquerque, the water table in simulation 4 is somewhat lower than that in simulation 6 , most likely because of the smaller estimate of $A_{V}$ in calibration 4 and consequent better connection of the shallow and deep parts of the ground-water flow system. In parts of the basin that are largely unaffected by pumping, the 1995 water table in both simulations is similar to that at steady state. Thus, west of the low-K fault zone in subsurface configuration 6 , the 1995 water table in simulation 6 remains as much as $160 \mathrm{ft}$ higher than that in simulation 4. In this region between the West Atrisco Fault and the Sand Hill Fault (fig. 3), measurement of the water table might help resolve whether the West Atrisco Fault is truly tightly cemented.

Simulated hydraulic head in model layer 5 (400 to $800 \mathrm{ft}$ below the Rio Grande) in 1995 is shown in figure 26. In the Albuquerque area both east and west of the Rio Grande, hydraulic heads in layer 5 of simulation 4 are about 5 to $30 \mathrm{ft}$ higher than those in simulation 6 . This difference in simulated conditions most likely occurs because the larger optimal estimate of $A_{V}$ in calibration 6 results in more restricted movement of water from the Rio Grande and shallower model layers to the deeper parts of the system under pumping conditions. Simulated conditions in model layer 7 (1,600 to $2,600 \mathrm{ft}$ beneath the Rio Grande), in which there is no simulated pumpage, also appear to reflect the different vertical anisotropy estimates in calibrations 4 and 6 (fig. 27). Ground-water withdrawal in the east part of Albuquerque from overlying model layers affects hydraulic heads in model layer 7 of simulation 4 , but this effect is less pronounced in layer 7 of simulation 6 .

Comparison of basinwide simulated conditions in 1995 (figs. 25 and 26) and contours of ground-water levels representative of winter 1994-95 conditions (fig. 4) shows that the model achieves limited success in reproducing observed large-scale ground-water flow patterns. In simulation 4 , the horizontal hydraulic gradient in the vicinity of the ground-water trough in the central-western part of the basin is similar to the observed gradient, whereas in simulation 6 , the horizontal hydraulic gradient is slightly steeper than the observed gradient. In the northwest part of the basin, simulations 4 and 6 both generally reproduce observed horizontal gradients and flow directions north of the Jemez River. South of the Jemez River, simulated flow directions appear to differ from observed flow directions, but ground-water level data are sparse in this region (fig. 4). In the northeast part of the basin, where the observed horizontal hydraulic gradient at the flanks of the basin is considerably steeper than that in the interior, the simulations fail to reproduce the observed gradients. In the southern part of the basin, simulations 4 and 6 both generally reproduce observed horizontal gradients and largescale flow directions.

In some parts of the Albuquerque Basin, conditions in simulations 4 and 6 are substantially different from those in previous flow models. At steady state in the northwestern part of the basin, the watertable gradient in both simulations 4 and 6 is steeper and hydraulic heads are as much as about $100 \mathrm{ft}$ higher than in the model of Kernodle and others (1995, fig. 18). In the west-central part of the basin, the water-table gradient in simulations 4 and 6 is flatter and hydraulic heads are as much as $50 \mathrm{ft}$ lower, compared with conditions in the model of Kernodle and others (1995). In 1995, the water table in the west-central part of the basin in simulations 4 and 6 is as much as 80 to $100 \mathrm{ft}$ lower than the simulated 1995 water table in the model of Kernodle (1998, fig. 22). In the Albuquerque area, there is slightly less drawdown in model layer 5 of simulation 4 and slightly. more drawdown in layer 5 of simulation 6 than at comparable depths in the model of Kernodle (1998, fig. 20).

\section{Ground-Water Budget}

The simulated transient ground-water budget for components of recharge to and discharge from the inner-yalley surface-water bodies is shown in figure 28. Because the Rio Grande, canals, drains, and Cochiti Reservoir are interconnected, separating the effects that these surface-water bodies have on both the true and simulated ground-water flow systems is difficult. In the flow model, until 1930, the Rio Grande is the only inner-valley surface-water body simulated. Beginning in 1930, the drains are simulated and immediately receive a large quantity of discharge, but as shown in figure 28 , the source of much of this discharge is recharge from the Rio Grande a short distance away. A similar phenomenon occurs regarding the interaction of Cochiti Reservoir and the Rio Grande 


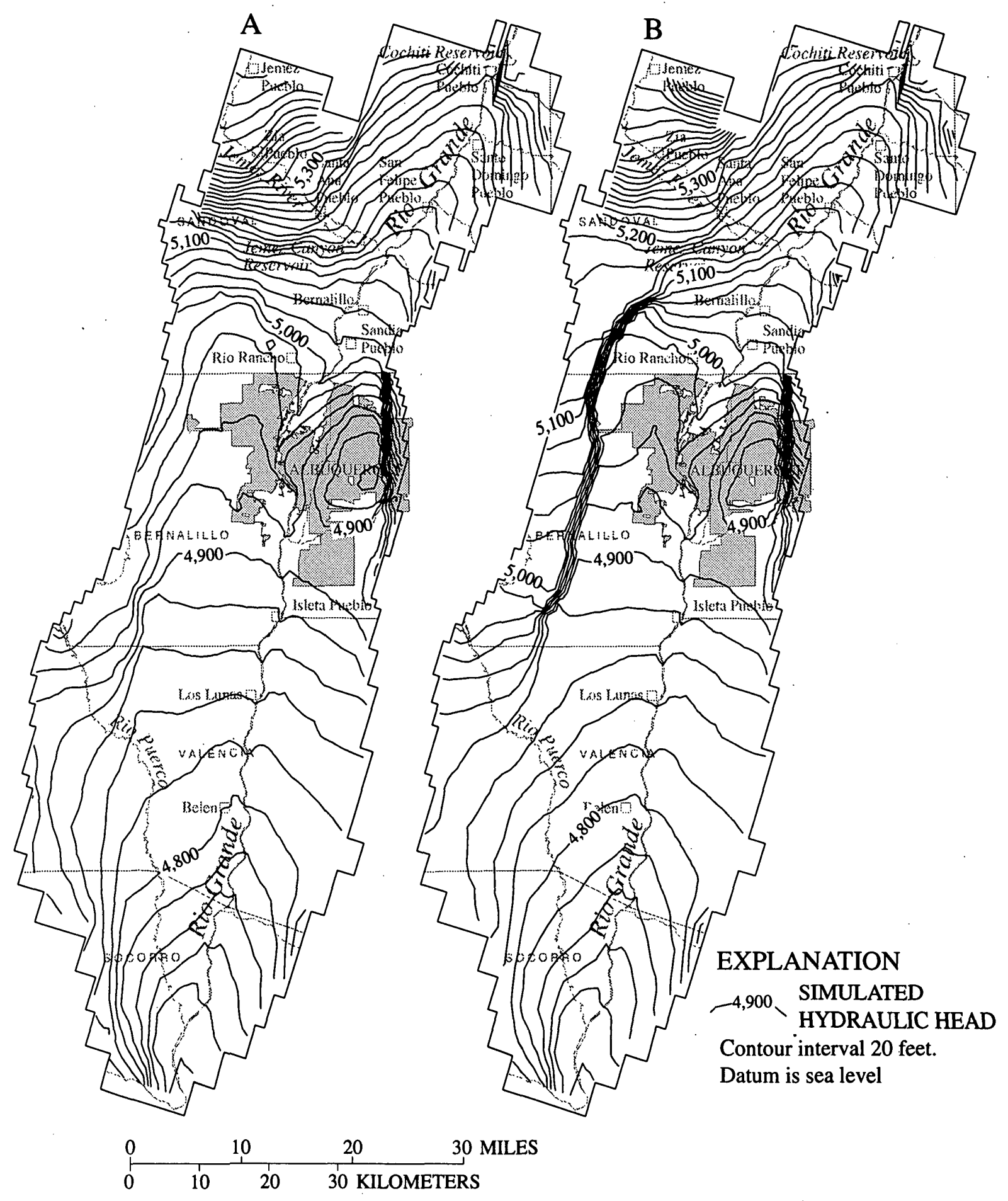

Figure 25. Simulated 1995 water table in (A) simulation 4 and (B) simulation 6. 


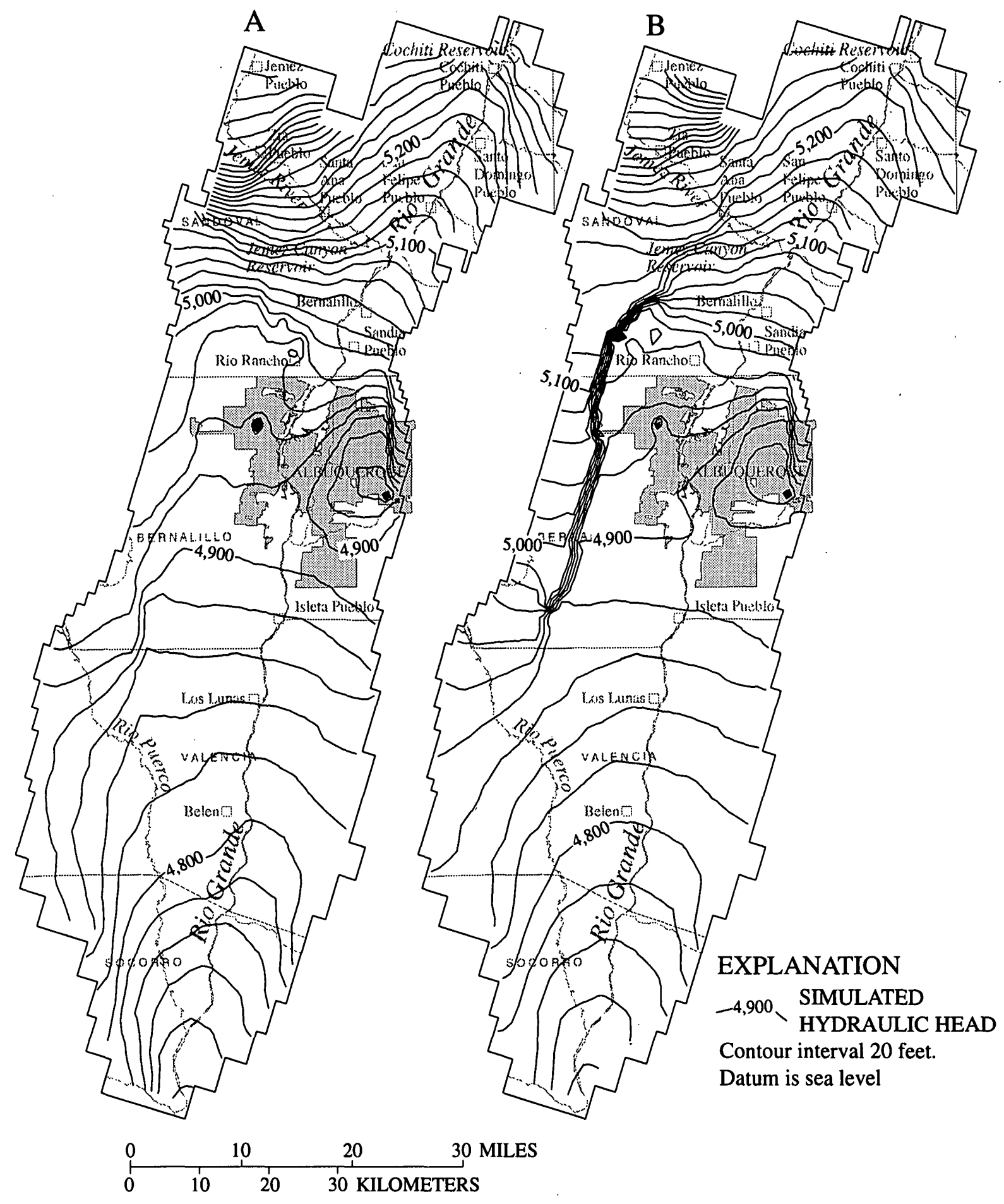

Figure 26. Simulated 1995 hydraulic heads in model layer 5 in (A) simulation 4 and (B) simulation 6. 


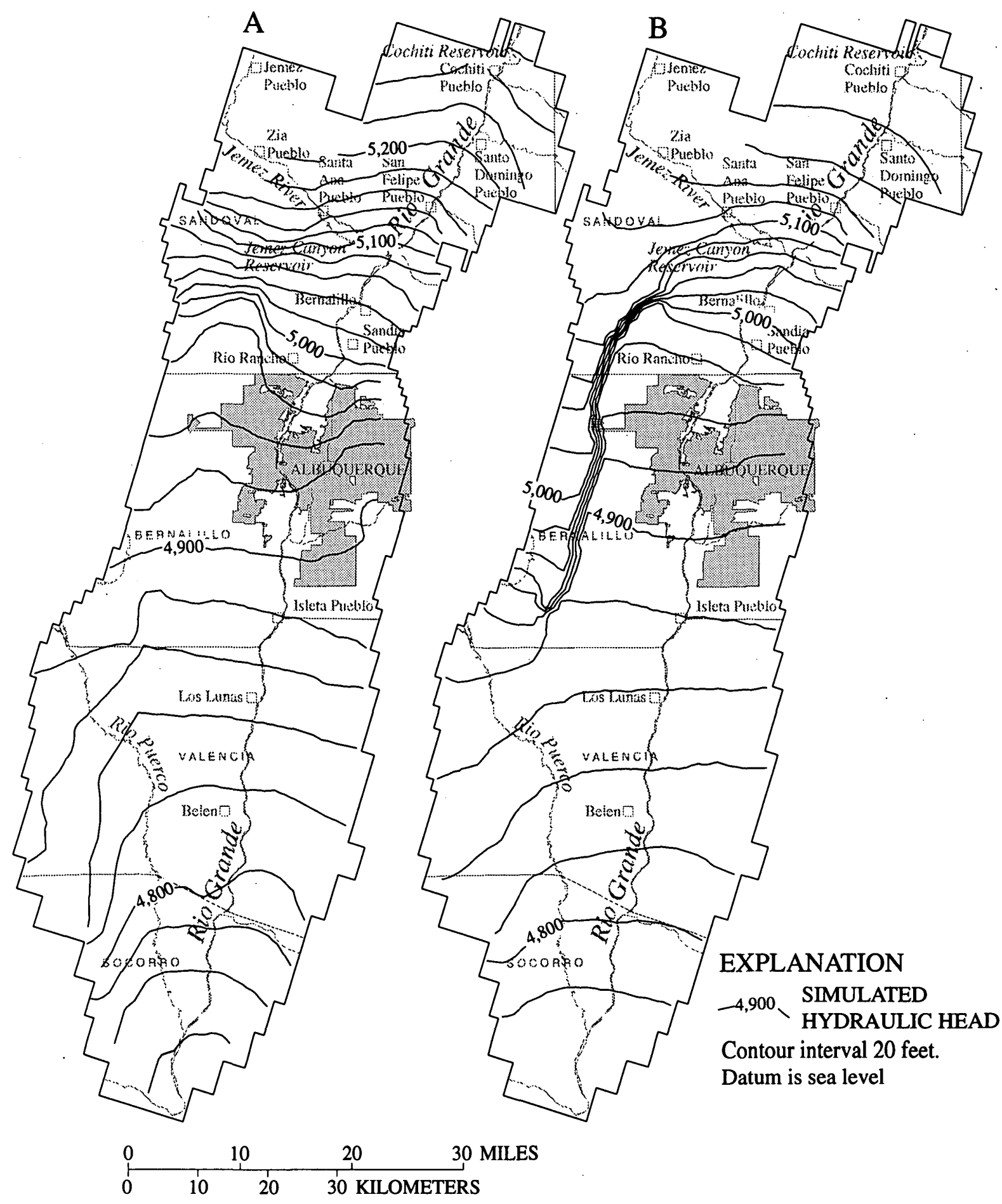

Figure 27. Simulated 1995 hydraulic heads in model layer 7 in (A) simulation 4 and (B) simulation 6. 


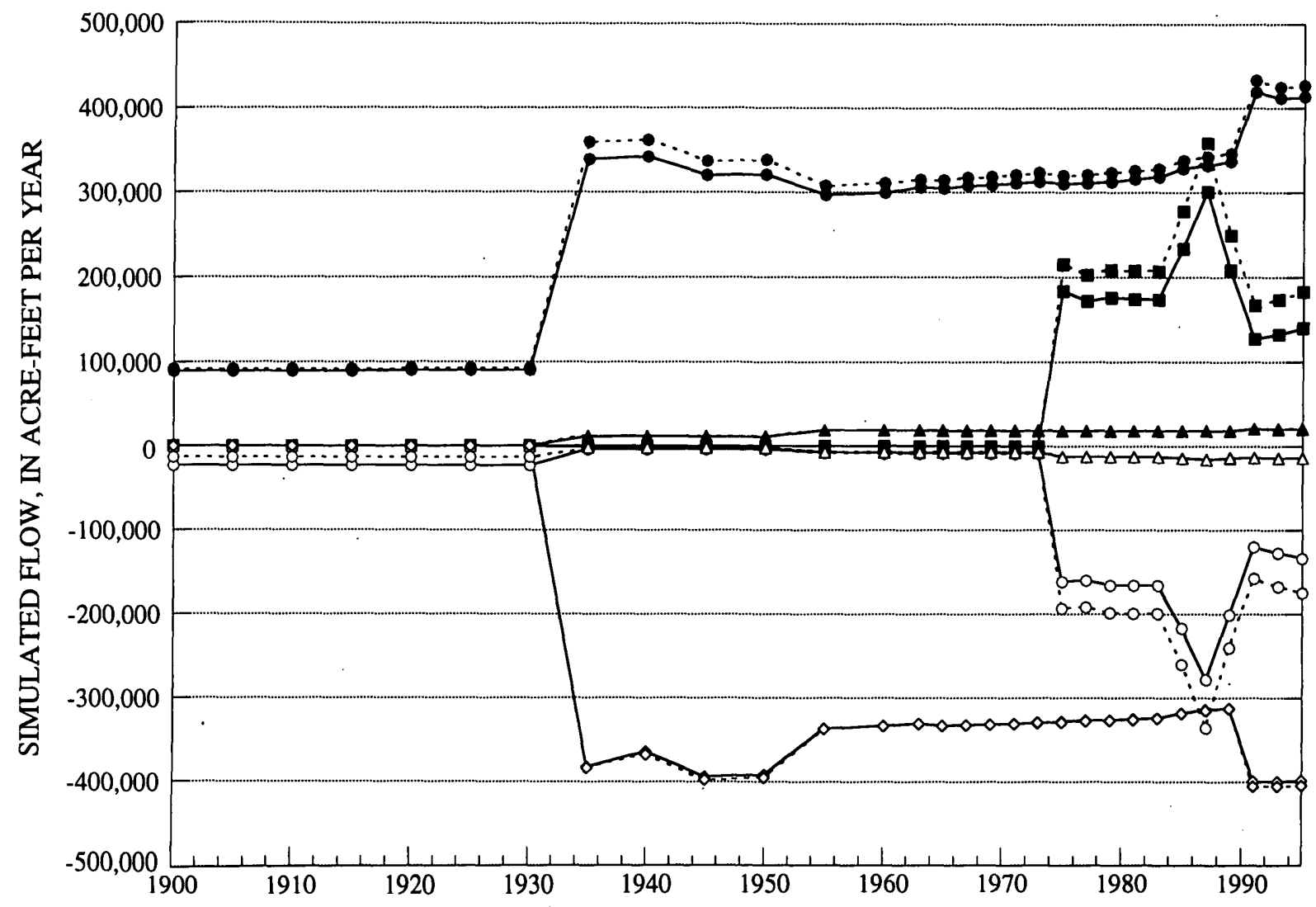

\section{EXPLANATION}

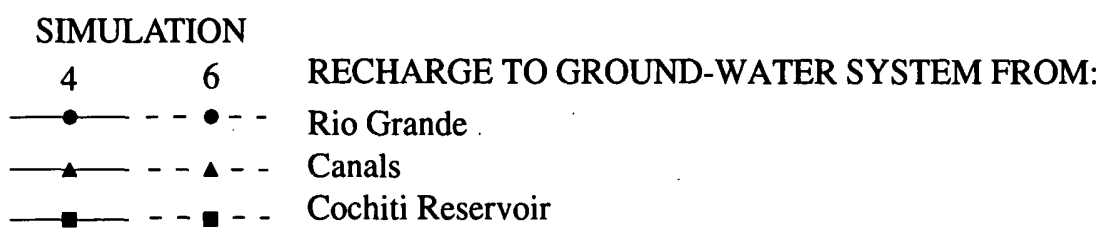

DISCHARGE FROM GROUND-WATER SYSTEM TO:

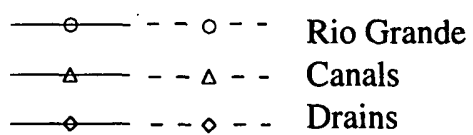

Figure 28. Simulated flow between inner-valley surface-water bodies and the ground-water system. Positive flow indicates recharge to the ground-water system; negative flow indicates discharge from the ground-water system. 
in the northern part of the basin beginning in the 1970 's. Because of this interconnectivity of the surface-water bodies, only the net flow between the ground-water system and the Rio Grande, canals, drains, and Cochiti Reservoir is presented below in relation to other ground-water-budget components.

The temporal trends in the water-budget components are identical in simulations 4 and 6 , although the magnitudes of some components differ (fig. 29). At steady state, water enters the ground-water system as recharge at mountain fronts and tributaries, underflow from adjacent areas $\left(Q_{U}\right)$, and net infiltration of Rio Grande water $\left(Q_{S W}\right)$, and discharges as evapotranspiration $\left(Q_{E}\right)$. In the 1930's, the drain network becomes active, additional sources of recharge are simulated, and pumpage $\left(Q_{W}\right)$ begins to increase. Consequently, net basinwide discharge to the innervalley surface-water system begins, mostly because of the presence of drains (fig. 28), and discharge to evapotranspiration decreases. The large increase in flow from storage $\left(Q_{S}\right)$ at this time is a consequence of the abrupt changes imposed on the system in the simulation; in reality these changes were more gradual and probably did not affect aquifer storage as greatly. In the 1950's, pumpage starts to dramatically increase. This increase is accompanied by an increase in $Q_{S}$ and a decrease in net discharge to the surface-water bodies in the inner valley. Beginning in the 1970's, there is again net infiltration of inner-valley surface water to the ground-water system. In the late 1980's, pumpage levels off and $Q_{S}$ and $Q_{S W}$ decrease. However, the simulations cannot be used to discern the effect of changes in pumpage on $Q_{S}$ and $Q_{S W}$ in the 1980's and 1990's because in 1984 and 1992 there are changes in the source of the GIS data bases used to determine temporal changes in model input for the evapotranspiration, river, drain, and canal boundary conditions. These changes affect the simulated values of $Q_{S}$ and $Q_{S W}$ in the 1980's and 1990's, and it is difficult to separate the effects of these changes from the effects of changes in pumpage. The graph of $Q_{E}$ (fig. 29) clearly shows the effect of the changes in the source of the GIS data base used to determine model input for the evapotranspiration boundary condition.

The budget components that differ by the greatest amount between simulations 4 and 6 are the net recharge from precipitation, stream water, and irrigation and septic seepage $\left(Q_{R}\right)$ and $Q_{S W}$. Throughout the simulation, $Q_{R}$ is about 12,000 acre- $\mathrm{ft} / \mathrm{yr}$ greater in simulation 4 than in simulation 6 (fig. 29), mostly because the estimate of $\mathrm{RM}_{\mathrm{Jemez}}$ is larger in simulation 4. The value of $Q_{S W}$ is about 9,000 to 20,000 acre-ft/yr smaller in simulation 4 compared with simulation 6 , in large part because much of the recharge along the Jemez River in simulation 4 flows through the west side of the basin and discharges to the inner-valley surface-water bodies south of about Isleta Pueblo (fig. 25). From the 1930's to the early 1970's, when $Q_{S W}$ is negative in both simulations (fig. 29), there is greater net basinwide discharge from the ground-water system to the inner-valley surface-water bodies in simulation 4 than in simulation 6 . From the early 1970 's to 1995 , when $Q_{S W}$ is positive, net recharge from these surface-water bodies to the ground-water system is smaller in simulation 4 than in simulation 6. Although comparison of the simulated equivalent of the flow observation in simulations 4 and 6 showed that net recharge to the ground-water system from the Rio Grande and riverside drains in the Albuquerque area in 1995 is larger in simulation 4, the greater discharge south of Isleta Pueblo in simulation 4 still results in a smaller value of $Q_{S W}$ in simulation 4 compared with that in simulation 6 .

Overall, the temporal trends in the water-budget components for simulations 4 and 6 are similar to those presented by Kernodle and others (1995, figs. 36 and 37), with the exception of the trend in discharge by evapotranspiration. Differences between the two models in the GIS data bases used to generate input for the evapotranspiration boundary condition and in land surface altitudes are probably the cause of the differences in the temporal trends in simulated evapotranspiration. Some components of the 1995 net basinwide ground-water budgets for simulations 4 and 6 are significantly different from those in the model of Kernodle (1998) (fig. 30). Compared to this previous model, $Q_{R}$ in simulations 4 and 6 is 20 to 27 percent smaller, $Q_{S}$ is 27 percent smaller, and $Q_{E}$ is 13 percent smaller. The most significant difference occurs for $Q_{S W}$. On a basinwide basis, there is net recharge from the inner-valley surface-water bodies to the groundwater system in simulations 4 and 6 , whereas there is net discharge from the ground-water system to the surface-water bodies in the previous model. 


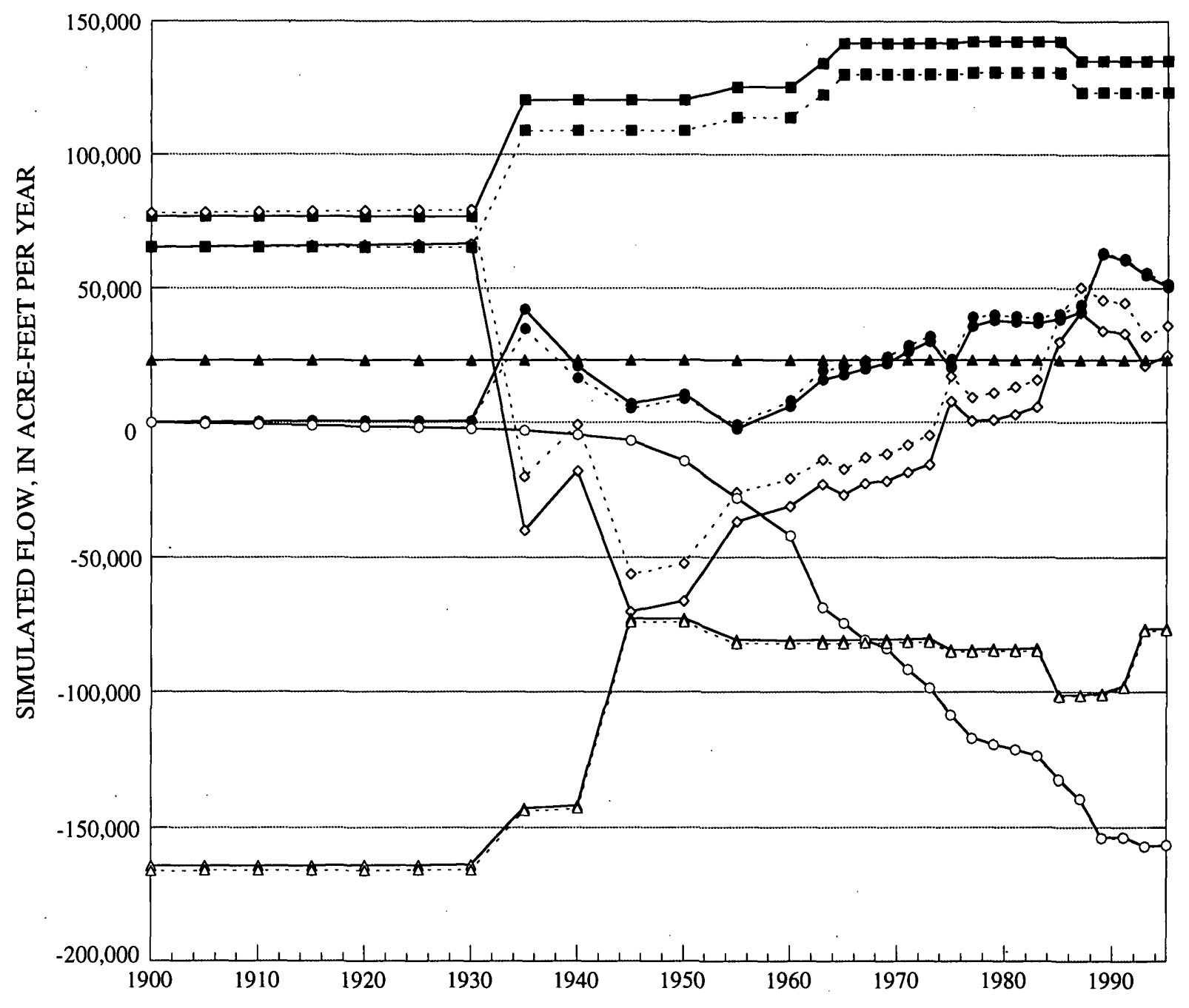

EXPLANATION

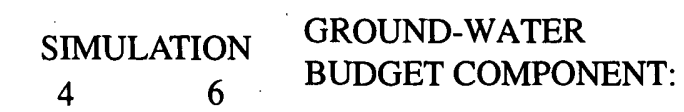

$\because \ldots-\ldots$ Net inflow from aquifer storage $\left(Q_{S}\right)$

$\ldots \ldots$ - . Underflow from adjacent regions $\left(Q_{U}\right)$

$\longrightarrow$ - - - Net recharge from precipitation, stream water, irrigation and septic seepage $\left(Q_{R}\right)$

- - - o- - Ground-water withdrawal $\left(Q_{W}\right)$

$-\Delta--\Delta-$. Evapotranspiration $\left(Q_{E}\right)$

$\_-\diamond_{-}-$Net flow between ground-water system and inner-valley surface-water bodies $\left(Q_{S W}\right)$

Figure 29. Simulated basinwide transient ground-water budget. Positive flow indicates inflow to the ground-water system; negative flow indicates outflow from the ground-water system. 


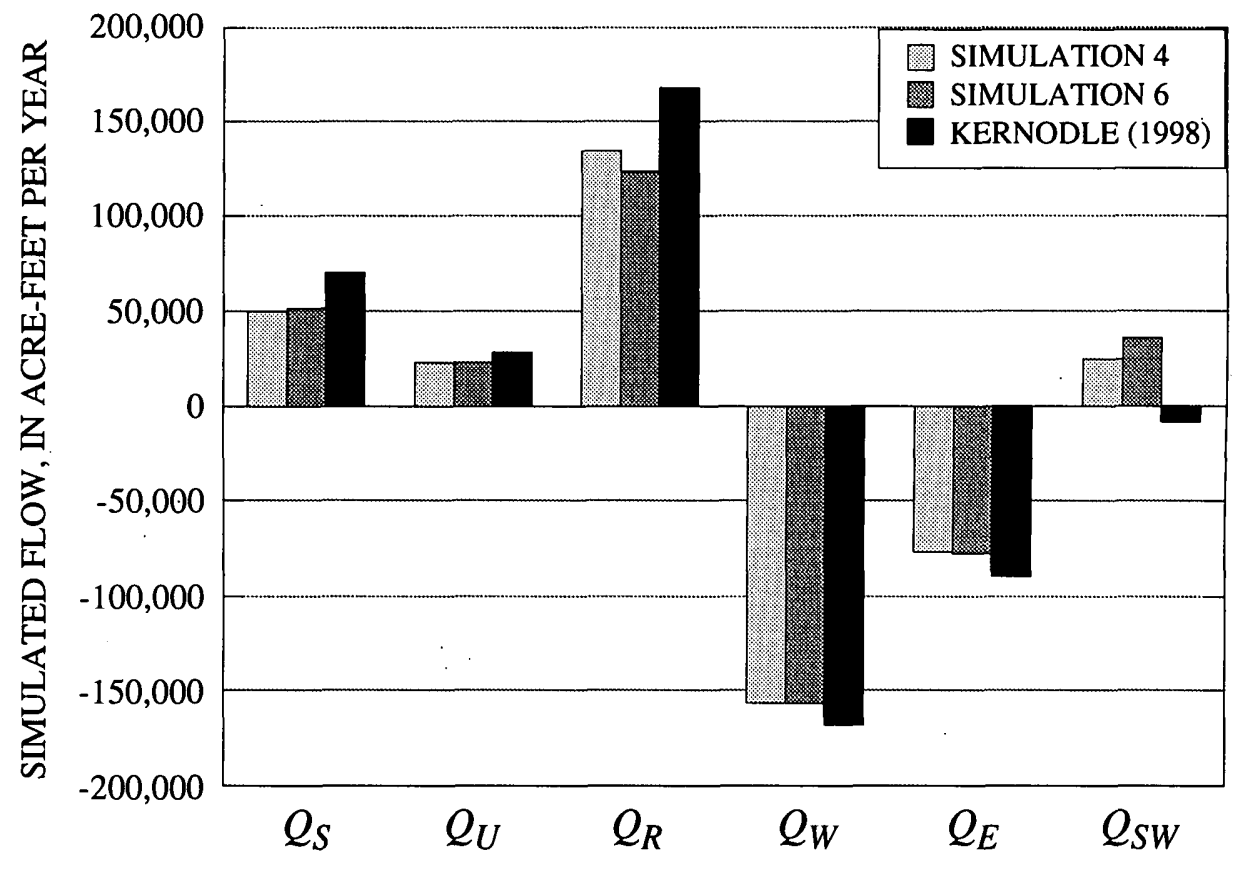

GROUND-WATER BUDGET COMPONENT

Figure 30. Simulated basinwide 1995 ground-water budget. Positive flow indicates inflow to the ground-water system; negative flow indicates outflow from the ground-water system. See figure 29 for description of ground-water budget components.

\section{SUMMARY AND CONCLUSIONS}

In the Albuquerque Basin, ground water is the primary source for all water uses except agricultural irrigation. Withdrawal of ground water has steadily increased since the 1940's, resulting in large waterlevel declines in the Albuquerque area. Beginning in the 1980's, numerical models of ground-water flow in the basin have been developed for the purposes of understanding the hydrologic system and managing the basin ground-water resources. Flow models developed in 1994 and 1995 that incorporate the understanding of the basin hydrogeology as of the mid-1990's were not rigorously calibrated because of the large computation times required for a model simulation. In the work presented here, nonlinear-regression methods were applied to a version of these previous models in which the spatial and temporal discretization was coarsened, to shorten the simulation time. The primary goals of this work were to use regression methods to calibrate the model with each of six different configurations of the basin subsurface and to assess and compare optimal parameter estimates, model fit, and model error among the resulting calibrations.

The Albuquerque Basin is one of several structural basins that constitute the Rio Grande Rift, a region formed by Cenozoic extension that stretches from Colorado to northern Mexico. The 3,060-squaremile basin is bounded by mountains, uplifts, and fault zones. Basin deposits include pre-Santa Fe deposits, Tertiary Santa Fe Group basin fill, post-Santa Fe Pleistocene volcanic rock, and post-Santa Fe Quaternary sediments. The Santa Fe Group is the predominant basin deposit, and is greater than 14,000 $\mathrm{ft}$ thick in the central part of the basin. This unit has been divided into lower, middle, and upper parts, on the basis of depositional environment and age. Crustal extension occurring at the time of Santa Fe Group deposition caused north trending normal faults to develop throughout the Albuquerque Basin, with vertical displacements of up to $30,000 \mathrm{ft}$. Post-Santa Fe Group geologic units include river alluvium that is on average $80 \mathrm{ft}$ thick, and volcanic rock emplaced in the western part of the basin. 
Ground-water flow in the basin occurs primarily in the Santa Fe Group and post-Santa Fe Group deposits. Surface-water bodies in the inner valley of the basin, including the Rio Grande, a network of extensively interconnected canals and drains, and the Cochiti Reservoir, have a strong influence on the ground-water flow system. Inflows to the ground-water system include recharge along mountain fronts and tributaries to the Rio Grande; subsurface flow from adjacent basins; septic field and irrigation return flow; and recharge from the Rio Grande, canals, and Cochiti Reservoir. Ground water discharges by pumpage; evapotranspiration; subsurface flow to the south; and flow to the Rio Grande, drains, and canals.

The transient, three-dimensional numerical model of ground-water flow to which nonlinearregression methods were applied simulates groundwater flow in the Albuquerque Basin from 1900 through March 1995. The delineation of the basin hydrogeologic units in the flow model is similar to that in the 1995 model except that in this study, six different configurations of the basin subsurface are considered. The configurations are designed to test the effects of (1) varying the simulated basin thickness, (2) including a hypothesized hydrogeologic unit with large permeability (the west basin high-K zone), and (3) substantially lowering the simulated hydraulic conductivity of a fault zone in the western part of the basin (the low-K fault zone).

Using the nonlinear least-squares regression method implemented in MODFLOWP, optimal parameter values were estimated for the model with each subsurface configuration. MODFLOWP does not support estimation of parameters for models with convertible layers and because of this limitation, model layers 2 and 3 are represented as confined during regression, in contrast to the more accurate method of simulating transient dewatering in the basin by representing layers 2 and 3 as convertible. To minimize the effect on regression results of the inaccurate simulation of dewatering, hydraulic-head data are included in the calibration data set only at locations where and for times at which simulated head in the model without convertible layers differs by less than 5 $\mathrm{ft}$ from simulated head in the model with convertible layers. The resulting calibration data set contains 802 hydraulic-head observations that provide broad spatial and temporal coverage of basin conditions and one observation of flow from the Rio Grande and riverside drains to the ground-water system in the Albuquerque area. The hydraulic-head data include measurements from wells throughout the basin from 1950 through 1960, in 1992, and in 1994, and measurements from 17 wells and 14 piezometer nests for several years. Data were weighted on the basis of estimated standard deviations of measurement error. There is large uncertainty associated with the flow observation and thus it has a small weight and little influence on the estimated parameters. The 10 to 12 parameters to which the calibration data as a whole are generally the most sensitive are estimated and the remaining model parameters are specified. Estimated parameters include recharge along Jemez River, Rio Puerco, and segments of the mountains bordering the east basin; the hydraulic conductivity of five subunits of the Santa Fe Group, the Rio Grande alluvium, and the west basin high-K zone; and the vertical anisotropy of the basin sediments.

Results indicate that the optimal parameter estimates as a whole are most reasonable in the calibrated model with subsurface configuration 3 (which contains 1,600-ft-thick basin deposits and the west basin high-K zone), configuration 4 (which contains 5,000-ft-thick basin deposits and the west basin high-K zone), and configuration 6 (which contains 5,000-ft-thick basin deposits and the low-K fault zone). However, in calibrations 3 and 6 the estimates of the hydraulic conductivity of the undivided upper part of the Santa Fe Group ( $\mathrm{K}_{\mathrm{USF} 1}$ ) and the Zia Sand of the lower part of the Santa Fe Group $\left(\mathrm{K}_{\mathrm{LSF}-\mathrm{Z}}\right)$ remain outside the reasonable ranges of parameter values, whereas in calibration 4 the estimate of $\mathrm{K}_{\mathrm{USF} 1}$ remains outside the expected range. The estimate of $\mathrm{K}_{\mathrm{USF} 1}$ is much closer to the reasonable range in calibrations 3,4 , and 6 than in calibrations 1 and 2 , however, partly because addition of the west basin high-K zone or the low-K fault zone to the model results in lower simulated hydraulic heads in the western part of the basin and consequently a better match of simulated and observed heads in that region. In calibrations of the model with subsurface configurations 1 and 2, which contain neither the west basin high-K zone nor the low-K fault zone, lower simulated heads in the western part of the basin are achieved in part by increasing the estimate of $\mathrm{K}_{\mathrm{USF} 1}$ such that it is much farther from the reasonable range than in calibrations 3,4 , and 6 .

The result that some optimal parameter estimates remain outside the expected ranges in calibrations 3,4 , and 6 indicates that the model is not yet completely satisfactory and strongly suggests that further 
modifications need to be made to the conceptual model of the basin hydrology and geology that is implemented in the numerical flow model.

Furthermore, the west basin high-K zone and the low$\mathrm{K}$ fault zone in the model are designed to test the concept that a highly permeable unit or a tightly cemented fault in the western part of the basin might play a role in lowering hydraulic heads in the vicinity of a ground-water trough in this part of the basin. It is highly likely that there are other modifications to the basin structure, configuration of hydrogeologic units, and boundary conditions that might achieve this effect and result in more reasonable optimal parameter estimates than those in the calibrations presented here.

Although the model is not yet completely satisfactory, evaluation of model fit and model error for calibrations with the most reasonable parameter estimates is useful for identifying locations of problems with the model and for comparing results of the calibrations. The standard errors of regression for calibrations 4 and 6 are each equal to about 3.5, which is about 15 percent smaller than those for calibrations 1 and 2. Assessment of the spatial distribution of the weighted hydraulic-head residuals for calibrations 4 and 6 reveals that for simulations of conditions in the 1950 's, most weighted hydraulic-head residuals are small and there are no severe problems with clusters of same-sign weighted residuals. For conditions in 1994, weighted hydraulic-head residuals at shallow wells in the southern part of the basin are generally small but mostly negative for both calibrations. In calibrations 4 and 6, the optimal estimate of $\mathrm{K}_{\mathrm{USF} 1}$ is larger than the range of expected values partly because this estimate improves model fit in the south, suggesting likely error in the representation of hydrogeologic units in this region. Poor model fit and patterns exhibited by weighted hydraulic-head residuals at shallow wells in the northern part of the basin indicate likely model error, which is not surprising because recent geologic studies in this region suggest there is much more heterogeneity in geologic conditions than is depicted in the flow model. The weighted residuals at deep wells in the Albuquerque area are generally larger for the 1990's than for the 1950's, suggesting that model error derived from the temporal and spatial averaging of true pumpage and from the assumed contribution of different model layers to total pumpage in a well could increase with increases in total pumpage from the ground-water system. At the deep wells, clustering of positive weighted residuals in the inner valley and of negative weighed residuals in west Albuquerque is also indicative of model error, possibly related to overly homogeneous representation of hydrogeologic units in this area.

In the northwestern part of the basin, there are large differences in the magnitude and sign of some weighted residuals for calibrations 4 and 6 , which result from the different hydraulic-conductivity zonation in the western part of the basin of subsurface configurations 4 and 6 , as well as from different optimal estimates of hydraulic conductivity and recharge in the northwestern part of the model in calibrations 4 and 6 . However, neither of the calibrations provides an obviously superior fit to the data in this part of the model. The fit to data at the deep intervals of two piezometer nests in the western part of the basin, where simulated heads are strongly affected by the presence of the west basin high-K zone and the low-K fault zone, is generally better in calibration 4 than in calibration 6. Within Albuquerque, positive weighted hydraulic-head residuals for deep wells in the inner valley in the 1990's are significantly smaller in calibration 4 compared with calibration 6 . In this area, simulated hydraulic heads are too low in both calibrations, but are lower in calibration 6 because the larger estimate of vertical anisotropy in this calibration results in less connection of the river and shallow ground-water flow system to the deeper flow system, and greater pumping-induced drawdown in the deeper system, than in calibration 4 .

To assess the model fit in a manner that is unaffected by the weighting used in the regression, hydraulic heads in simulations 4 and 6 , in which model layers 2 and 3 are represented as convertible, are compared to observed hydraulic heads. For simulations of conditions during the 1950's, hydraulic heads in simulations 4 and 6 differ by less than $20 \mathrm{ft}$ from observed heads at most shallow and deep wells. For simulations of conditions during the 1990's, head differences at the shallow wells are less than $20 \mathrm{ft}$ at many locations in the basin interior, but are commonly greater than $40 \mathrm{ft}$ in the northern part of the basin and near Cat Mesa Fault. At the deep wells in the Albuquerque area, there is a fairly even distribution of small and large head differences.

Simulations 4 and 6 generally produce a similar fit to observations at the hydrograph wells, and temporal patterns in the data are generally reproduced. Comparison of the fit at closely spaced wells $\mathrm{E}$ and W suggests that subsurface conditions in the vicinity of 
these two wells likely are not as homogeneous as portrayed in the model. At many piezometer nests, simulations 4 and 6 provide a substantially different fit to observed hydraulic heads and vertical hydraulic gradients because the estimate of vertical anisotropy in calibration 6 is about four times larger than that in calibration 4 and the data suggest that vertical anisotropy is spatially variable. At piezometer nests in the Albuquerque area and on the west mesa, simulation 4 generally produces a better fit where the observed vertical gradients are small, whereas simulation 6 produces a better fit where the observed vertical gradients are larger. The fit to heads and vertical gradients at two piezometer nests in the northwestern part of the basin near the Jemez River is fair to poor, and the analysis of the results suggests that underflow at depth from areas outside the Albuquerque Basin may be a larger source of inflow than is currently simulated in the model.

The weighted flow residual in calibrations 4 and 6 is very small because of the small weight assigned to the flow observation. Despite the small influence that the flow observation has in the regression, the simulated equivalent of the flow observation in calibrations 4 and 6 is well within the range of uncertainty in the observed flow. The simulated equivalent of the flow observation in simulations 4 and 6 is, respectively, 46,800 and 39,800 acre-ft/yr. These flows are 61 and 37 percent larger than the 29,000 -acre$\mathrm{ft} / \mathrm{yr}$ flow observation used in the regression.

Differences in the steady-state water table for simulations 4 and 6 primarily occur west of the Rio Grande in the central and northern parts of the basin, where simulated conditions are affected by the west basin high-K zone in subsurface configuration 4 or by the low-K fault zone in configuration 6 . In 1995, these differences persist in parts of the basin that are largely unaffected by pumping. West of the low-K fault zone in configuration 6 , the water table in simulation 6 is as much as $160 \mathrm{ft}$ higher than that in simulation 4. In this region between the West Atrisco and Sand Hill Faults, measurement of the water table might help resolve whether the West Atrisco Fault is tightly cemented. In areas of ground-water withdrawals, differences in simulated hydraulic heads also occur, most likely as a result of the smaller estimate of vertical anisotropy in calibration 4, and consequent better connection of the river and shallow ground-water system with the deeper system, compared with calibration 6 .
The temporal trends in the basinwide groundwater-budget components for simulations 4 and 6 are identical. Differences between the budget components for the two simulations include net recharge from precipitation and stream water, which is about 12,000 acre-ft/yr larger in simulation 4 than in simulation 6 , mostly because the estimate of recharge along the Jemez River is larger in calibration 4 . The larger recharge in the northwestern part of the basin in simulation 4 results in greater discharge to the innervalley surface-water bodies in the southern part of the basin.

\section{REFERENCES CITED}

Bartolino, J.R., ed., 1997, U.S. Geological Survey Middle Rio Grande Basin Study--Proceedings of the first Annual Workshop, Denver, Colorado, November 1214, 1996: U.S. Geological Survey Open-File Report $97-$ $116,91 \mathrm{p}$.

Bjorklund, L.J., and Maxwell, B.W., 1961, Availability of ground water in the Albuquerque area, Bernalillo and Sandoval Counties, New Mexico: New Mexico State Engineer Technical Report 21, $117 \mathrm{p}$.

Blanchard, P.J., 1993, Ground-water-level fluctuations in the Cochiti Dam-Peña Blanca area, Sandoval County, New Mexico, 1976-89: U.S. Geological Survey WaterResources Investigations Report 92-4193, 72 p.

Blaney, H.F., Ewing, P.A., Israelsen, O.W., Rohwer, Carl, and Scobey, F.C., 1938, Water utilization, in (U.S.) National Resources Committee, Regional Planning part VI--The Rio Grande joint investigation in the upper Rio Grande basin in Colorado, New Mexico, and Texas, 1936-37: U.S. Government Printing Office, v. 1, p. 293427.

Bureau of Reclamation, 1973, Progress report--Phreatophyte investigations--Bernardo evapotranspirometers: Middle Rio Grande Project Office, $50 \mathrm{p}$.

Cooley, R.L., and Naff, R.L., 1990, Regression modeling of ground-water flow: U.S. Geological Survey Techniques of Water-Resources Investigations, book 3, chap. B4, $232 \mathrm{p}$.

Cummins, Billy, 1997a, Middle Rio Grande Water Assessment--Analysis of soil textures and permeabilities and deep percolation for Kentucky Bluegrass: U.S. Bureau of Reclamation, Albuquerque Area Office, Supporting document number 7, variously paged. 
Cummins, Billy, 1997b, Middle Rio Grande Water Assessment--Drilling, logging, monitoring, well installation, hydraulic conductivity tests, and infiltration gallery feasibility evaluation technical memoranda: U.S. Bureau of Reclamation, Albuquerque Area Office, Supporting document number 8, variously paged.

Draper, N.R., and Smith, Harry, 1981, Applied regression analysis (2d ed.): New York, Wiley, 709 p.

Frenzel, P.F., 1995, Geohydrology and simulation of groundwater flow near Los Alamos, north-central New Mexico: U.S. Geological Survey Water-Resources Investigations Report 95-4091, 92 p.

Frenzel, P.F., and Lyford, F.P., 1982, Estimates of vertical hydraulic conductivity and regional ground-water flow rates in rocks of Jurassic and Cretaceous age, San Juan Basin, New Mexico and Colorado: U.S. Geological Survey Water-Resources Investigations Report 824015, 59 p.

Gould, Jaci, 1997, Middle Rio Grande Water Assessment-Middle Rio Grande channel permeameter investigations: U.S. Bureau of Reclamation, Albuquerque Area Office, Supporting document number 11 , variously paged.

Gould, Jaci, and Hansen, Steve, 1997, Middle Rio Grande Water Assessment--Canal seepage field investigations performed November 1993: U.S. Bureau of Reclamation, Albuquerque Area Office, Supporting document number 12 , variously paged.

Grauch, V.J.S., and Sawyer, D.A., 1997, Detailed aeromagnetic surveys in the Middle Rio Grande Basin--Preliminary results: New Mexico Geology, v. 19 , no. 2 , p. 53.

Hawley, J.W., 1996, Hydrogeologic framework of potential recharge areas in the Albuquerque Basin, central New Mexico, in Hawley, J.W., and Whitworth, T.M., eds., Hydrogeology of potential recharge areas and hydrogeochemical modeling of proposed artificialrecharge methods in basin- and valley-fill aquifer systems, Albuquerque Basin, New Mexico: Socorro, New Mexico Bureau of Mines and Mineral Resources Open-File Report 402-D, chap. 1.

Hawley, J.W., and Haase, C.S., 1992, Hydrogeologic framework of the northern Albuquerque Basin: Socorro, New Mexico Bureau of Mines and Mineral Resources Open-File Report 387, variously paged.

Hawley, J.W., Haase, C.S., and Lozinsky, R.P., 1995, An underground view of the Albuquerque Basin, in OrtegaKlett, C.T., ed., The water future of Albuquerque and Middle Rio Grande Basin: Proceedings of the 39th Annual New Mexico Water Conference, November 34, 1994, New Mexico Water Resources Research Institute WRRI Report No. 290, p. 37-55.

Hearne, G.A., and Dewey, J.D., 1988, Hydrologic analysis of the Rio Grande Basin north of Embudo, New
Mexico, Colorado and New Mexico: U.S. Geological Survey Water-Resources Investigations Report 864113, 244 p.

Heywood, C.E., 1992, Isostatic residual gravity anomalies of New Mexico: U.S. Geological Survey Water-Resources Investigations Report 91-4065, 27 p.

1995, Piezometric-extensometric estimations of specific storage in the Albuquerque Basin, New Mexico, in U.S. Geological Survey Subsidence Interest Group Conference--Proceedings of the Technical Meeting, Las Vegas, Nevada, February 14-16, 1995: U.S. Geological Survey Open-File Report 97-47, 37 p.

Hill, M.C., 1990, Preconditioned conjugate-gradient 2 (PCG2), a computer program for solving ground-water flow equations: U.S. Geological Survey WaterResources Investigations Report 90-4048, 43 p.

-1992, A computer program (MODFLOWP) for estimating parameters of a transient, three-dimensional, ground-water flow model using nonlinear regression: U.S. Geological Survey Open-File Report 91-484, $358 \mathrm{p}$.

-1994, Five computer programs for testing weighted residuals and calculating linear confidence and prediction intervals on results from the ground-water parameter-estimation computer program MODFLOWP: U.S. Geological Survey Open-File Report 93-481, 81 p.

-1998, Methods and guidelines for effective model calibration: U.S. Geological Survey Water-Resources Investigations Report 98-4005, 90 p.

Johnson, A.I., 1967, Specific yield--Compilation of specific yields for various materials: U.S. Geological Survey Water-Supply Paper 1662-2, 74 p.

Kelley, V.C., 1977, Geology of Albuquerque Basin, New Mexico: Socorro, New Mexico Bureau of Mines and Mineral Resources Memoir 33, 60 p.

Kernodle, J.M., 1992, Summary of U.S. Geological Survey ground-water-flow models of basin-fill aquifers in the Southwestern Alluvial Basins region, Colorado, New Mexico, and Texas: U.S. Geological Survey Open-File Report 90-361, 81 p.

1998, Simulation of ground-water flow in the Albuquerque Basin, central New Mexico, 1901-95, with projections to 2020--Supplement two to U.S. Geological Survey Water-Resources Investigations Report 94-4251: U.S. Geological Survey Open-Filè Report 96-209, 54 p.

Kernodle, J.M., McAda, D.P., and Thorn, C.R., 1995, Simulation of ground-water flow in the Albuquerque Basin, central New Mexico, 1901-1994, with projections to 2020: U.S. Geological Survey WaterResources Investigations Report 94-4251, 114 p., 1 pl. 
Kernodle, J.M., Miller, R.S., and Scott, W.B., 1987, Threedimensional model simulation of transient groundwater flow in the Albuquerque-Belen Basin, New Mexico: U.S. Geological Survey Water-Resources Investigations Report 86-4194, 86 p.

Kernodle, J.M., and Scott, W.B., 1986, Three-dimensional model simulation of steady-state ground-water flow in the Albuquerque-Belen Basin, New Mexico: U.S. Geological Survey Water-Resources Investigations Report 84-4353, 58 p.

McAda, D.P., 1996, Plan of study to quantify the hydrologic relations between the Rio Grande and the Santa Fe Group aquifer system near Albuquerque, central New Mexico: U.S. Geological Survey Water-Resources Investigations Report 96-4006, 58 p.

McAda, D.P., and Wasiolek, Maryann, 1988, Simulation of the regional geohydrology of the Tesuque aquifer system near Santa Fe, New Mexico: U.S. Geological Survey Water-Resources Investigations Report 87 4056, 71 p.

McDonald, M.G., and Harbaugh, A.W., 1988, A modular three-dimensional finite-difference ground-water flow model: U.S. Geological Survey Techniques of WaterResources Investigations, book 6, chap. A1, 586 p.

Meeks, T.O., 1949, The occurrence of ground water in the Tijeras Soil Conservation District, Bernalillo County, New Mexico: U.S. Department of Agriculture, Soil Conservation Service Regional Bulletin 109, Geological Series 1, 19 p.

Poeter, E.P., and Hill, M.C., 1997, Inverse models--A necessary next step in ground-water modeling: Ground Water, v. 35, no. 2, p. 250-260.

Slate, J.L., ed., 1998, U.S. Geological Survey Middle Rio Grande Basin Study--Proceedings of the second Annual Workshop, Albuquerque, New Mexico, February 10-11, 1998: U.S. Geological Survey OpenFile Report 98-337, 91 p.

Smith, G.A., and Kuhle, A.J., 1998, Hydrostratigraphic implications of new geological mapping in the Santo Domingo Basin, New Mexico: New Mexico Geology, v. 20 , no. 1 , p. 21-27.

Thomas, C.L., 1995, Infiltration and quality of water for two arroyo channels, Albuquerque, New Mexico, 1988-92: U.S. Geological Survey Water-Resources Investigations Report 95-4070, 63 p.

Thorn, C.R., 1995, Surface-water discharge and evapotranspiration rates for grass and bare soil along a reach of the Rio Grande, Albuquerque, New Mexico, 1989-95: U.S. Geological Survey Open-File Report 95419, $23 \mathrm{p}$.

Thorn, C.R., McAda, D.P., and Kernodle, J.M., 1993, Geohydrologic framework and hydrologic conditions in the Albuquerque Basin, central New Mexico: U.S. Geological Survey Water-Resources Investigations Report 93-4149, 106 p.
Titus, F.B., Jr., 1961, Ground-water geology of the Rio Grande trough in north-central New Mexico, with sections on the Jemez Caldera and Lucero Uplift, in Northrop, A.A., ed., Guidebook of the Albuquerque Country: New Mexico Geological Society, 12th Field Conference, p. 186-192.

1963, Geology and ground-water conditions in eastern Valencia County, New Mexico: Socorro, New Mexico Bureau of Mines and Mineral Resources Ground-Water Report 7, 113 p.

Wilkins, D.W., 1987, Characteristics and properties of the basin-fill aquifer determined from three test wells west of Albuquerque, Bernalillo County, New Mexico: U.S. Geological Survey Water-Resources Investigations Report 86-4187, 78 p.

Willis, W.S., 1993, Middle Rio Grande ground-water studies: Bureau of Reclamation, Middle Rio Grande Water Assessment, Technical Memorandum, June 30, 1993 , variously paged. 


\section{APPENDIX: MODIFICATIONS TO MODFLOWP}

The MODFLOWP code was modified so that when multiple reaches are specified with the MODFLOW river package in a single model cell, flows between the underlying model layer and the river reaches are correct and sensitivities calculated by MODFLOWP are correct. The MODFLOW code allows multiple reaches specified with the river, drain, and/or general head boundary packages in a single model cell, but MODFLOWP is programmed such that parameter substitution and sensitivity calculations are incorrect for this situation. The modifications were made for the case of multiple reaches specified with the river package in a single model cell and have only been tested using this package. The modifications are necessary if (1) a boundary simulated using the river package (hereafter called a 'river boundary') includes model cells for which more than one river reach is specified and a parameter associated with this river boundary is defined in the MODFLOWP parameterestimation package input file (hereafter called the 'main MODFLOWP input file') or (2) there is a flow observation that involves model cells for which more than one river reach is specified.

There are three locations within the input files required for a MODFLOWP simulation where all or some of the cells that compose a river boundary may be listed. These are (1) in the MODFLOW river package input file; (2) in the main MODFLOWP input file, if a parameter associated with the boundary is defined in that input file; and (3) in the main MODFLOWP input file, if there is a flow observation that involves a river boundary. In the discussion below, and in some of the comments within the subroutines, these lists of cells are referred to, respectively, as (1) the boundary cells, (2) the PID cells (PID is the parameter identifier variable for parameters defined in the main MODFLOWP input file), and (3) the flow observation cells. The code modifications allow for the case in which the different reaches in a single cell are defined in different groups of PID cells in the MODFLOWP input file. These reaches will all be in one boundary cell list, however.

The modifications to the MODFLOWP code do not necessitate any new input files, but they do necessitate strict requirements regarding the ordering of the lists of cells in the input files. The new input requirements for the lists of boundary cells, PID cells, and flow observation cells are:
(1) Each list of PID cells associated with a river boundary must start with a cell in which there is only one river reach.

(2) The ordering of the list of PID cells must be exactly the same as the ordering of these cells in the list of boundary cells, and the PID cells must be listed consecutively in the list of boundary cells--no cells that are not in the PID list can be interspersed among them.

(3) The list of flow observation cells must start with a cell in which there is only one river reach.

(4) The ordering of the list of flow observation cells must be exactly the same as the ordering of these cells in the list of boundary cells, and the flow observation cells must be listed consecutively in the list of boundary cells.

The modified code was tested to ensure that the code changes produced the desired results. A simple test case was used that is based on test case 1 in Hill (1992) and that uses the river package instead of the streamflow routing package to simulate the river boundary. Additional river reaches were added so that one cell contained two river reaches. Flows to the river boundary simulated using the modified MODFLOWP code were equal to those simulated using the MODFLOW code. Flows calculated by the two codes were also the same for the more complex Albuquerque Basin model with numerous cells containing multiple river reaches. Sensitivities computed in the modified MODFLOWP code for the simple test case compared favorably to sensitivities calculated by a perturbation method. Sensitivities of hydraulic head to the riverbed conductance calculated by the modified MODFLOWP code differed by less than 0.05 percent from those calculated by the perturbation method. The sensitivity of simulated flow at the flow observation location to riverbed conductance calculated in the modified MODFLOWP code was about 0.2 percent different from that calculated by a perturbation method.

The four subroutines that were modified are part of MODFLOWP version 3.1 and are FLW1RP, SSEN1D, SSEN1K, and SSEN1V. A brief description of each subroutine and a listing of the changes made are given below. In the listing, added code is in bold, added comments begin with " $\mathrm{C}^{*}$ ", and when a line of the original code was commented out, the line begins with " $\mathrm{C}^{*}$ " and ends with the note "REMOVED LINE." 


\section{Subroutine FLW1RP}

In this subroutine, data for head-dependent flow boundaries are read, checked, and stored.

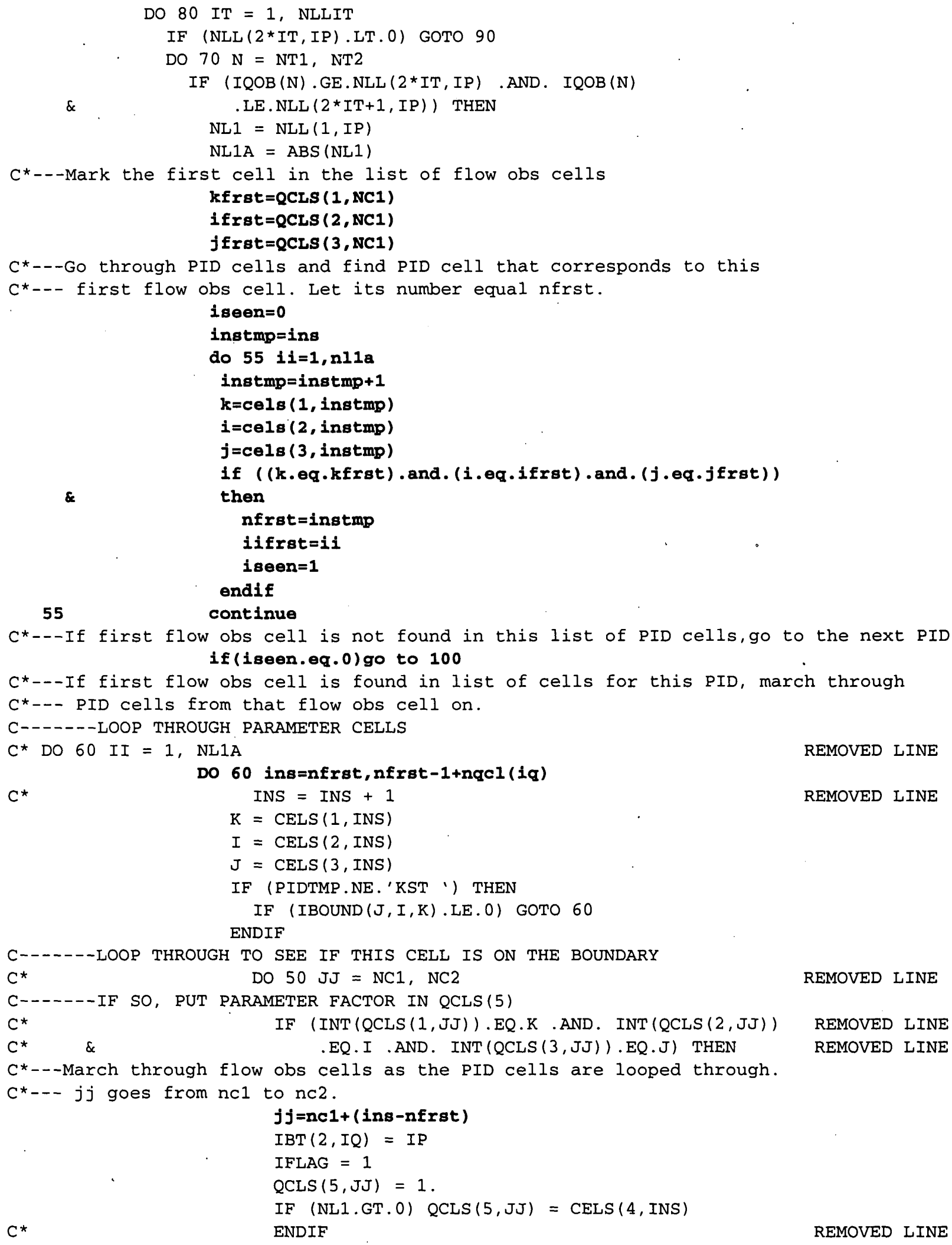




\section{Subroutine SSEN1D}

In this subroutine, components of the sensitivities for head-dependent boundaries are calculated.

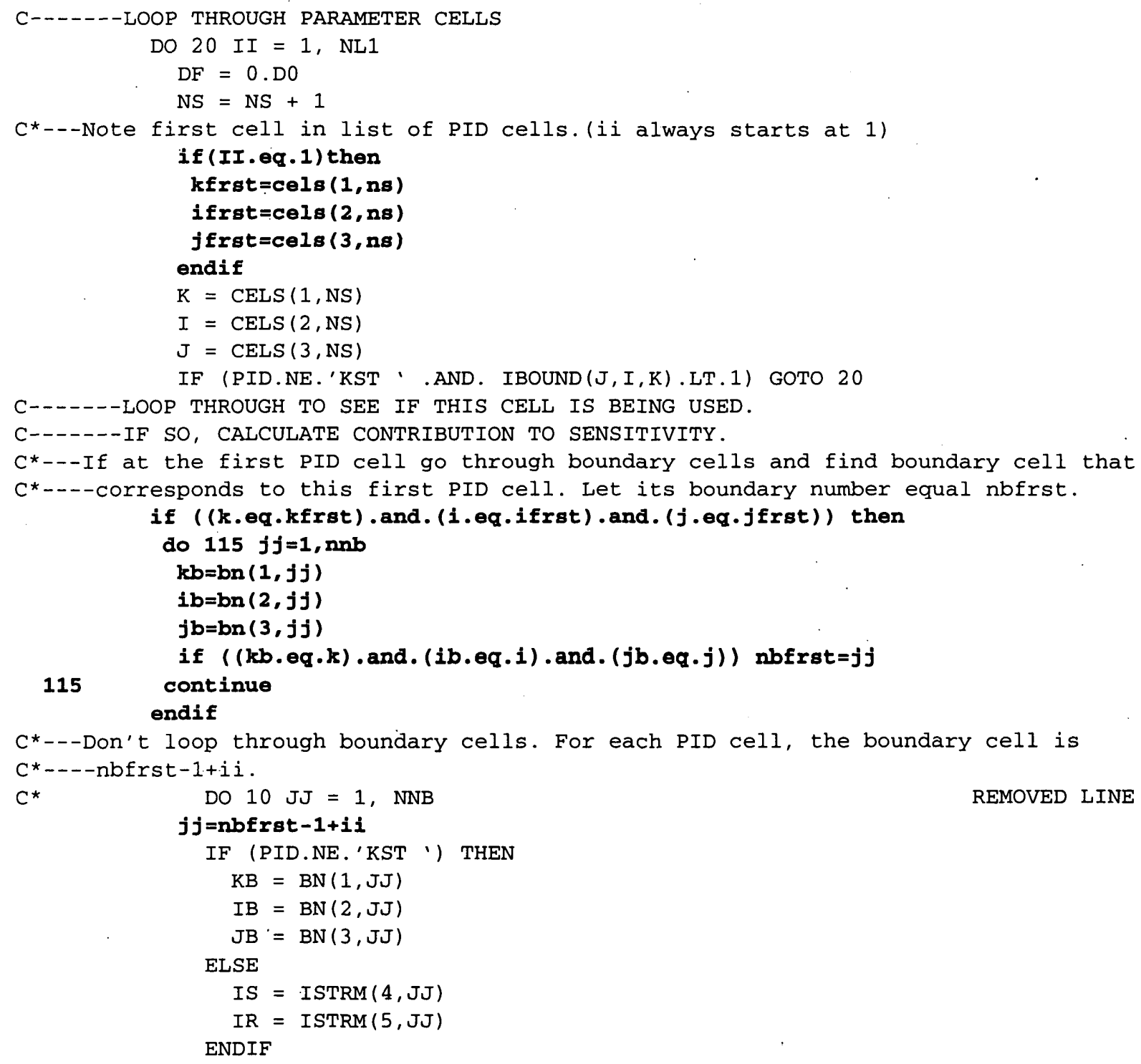




\section{Subroutine SSEN1K}

In this subroutine, new parameter values for head-dependent boundaries are put in flow-model arrays.

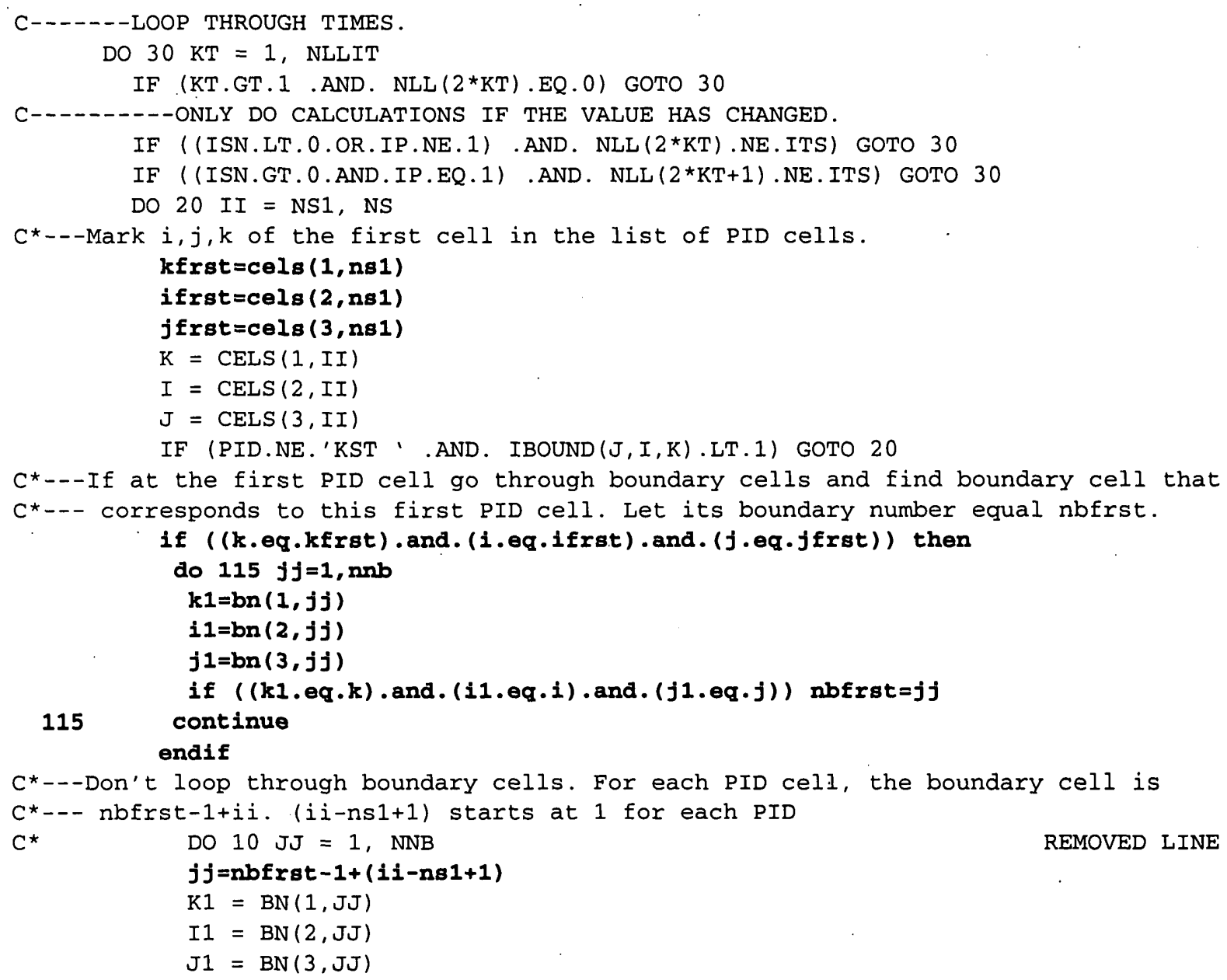




\section{Subroutine SSEN1V}

In this subroutine, simulated flow at the flow observation locations are saved, and sensitivities of simulated flow at the flow observation to model parameters are calculated.

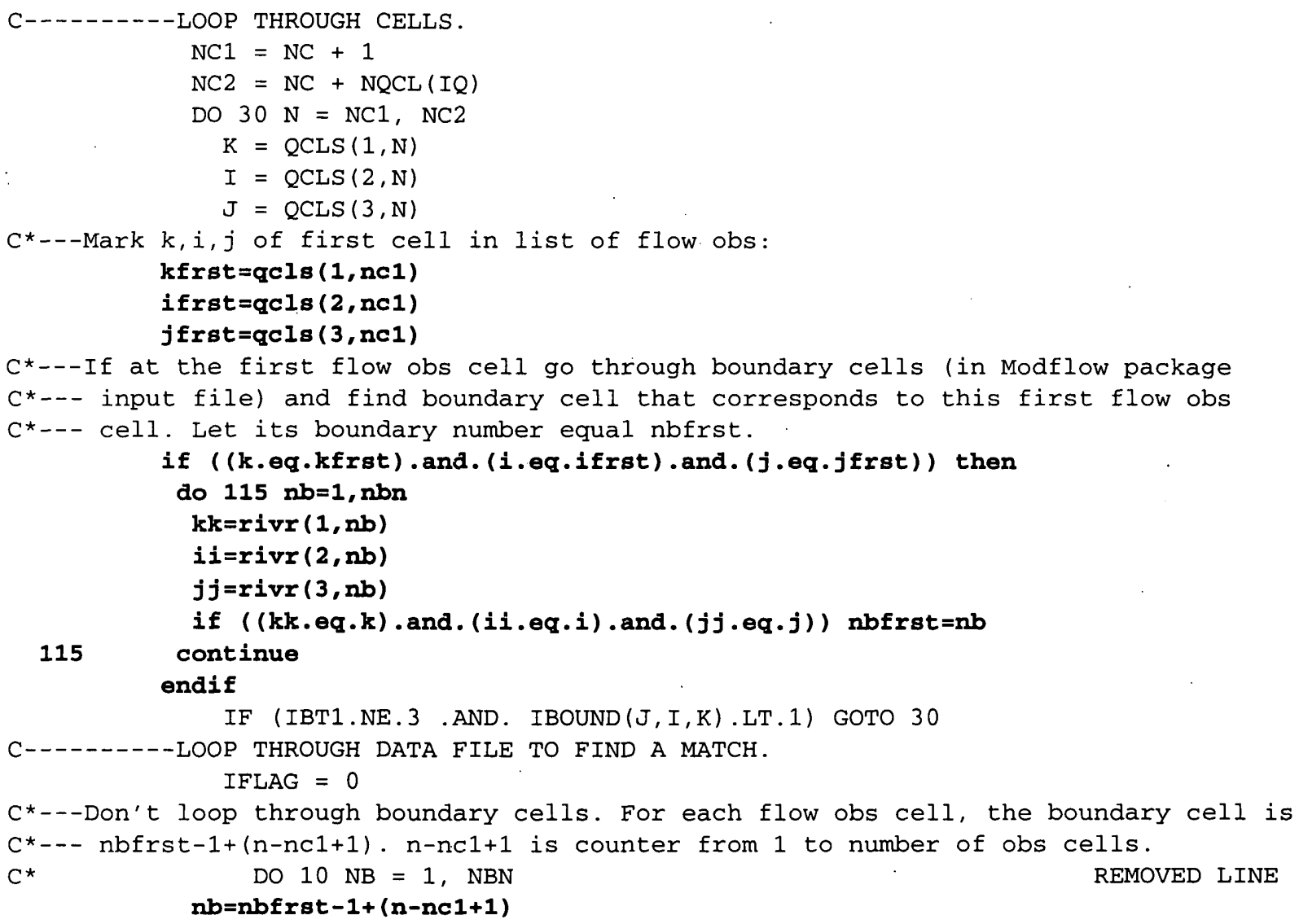




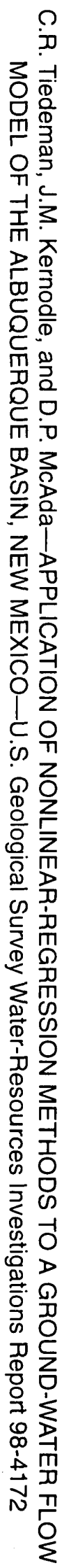

